Jordbrukslandskapet som ressurs i Norden

TemaNord 2004:537 
JORDBRUKSLANDSKAPET SOM RESSURS I NORDEN

Jordbrukslandskapet som ressurs i Norden

TemaNord 2004:537

(C) Nordisk Ministerråd, København 2004

ISBN 92-893-1030-8

ISSN $0908-6692$

Tryck: Scanprint as, Århus 2004

Forsidefoto: Ole Malling

Design: www.kursiv.no

Upplaga: 1000

Trykket på miljøvennlig papir som oppfyller kravene i den nordiske miljøsvanemerkingen.

Selges gjennom Nordisk ministerråds agenter, se siste siden.

\section{Nordisk ministerråd}

Store Strandstræde 18

DK-1255 København K

Telefon (+45) 33960200

Telefax (+45) 33960202

www.norden.org

\section{Nordisk råd}

Store Strandstræde 18

DK-1255 København K

Telefon (+45) 33960400

Telefax (+45) 33111870

\section{Det nordiska jord- och skogsbrukssamarbetet}

Jord- och skogsbruket i de nordiska länderna bygger på samma naturgivna förutsättningar och står ofta inför samma utmaningar. Mot denna bakgrund har det byggts upp ett traditionsrikt nordiskt samarbete. Nordiska ministerrådet (jord- och skogsbruksministrarna) prioriterar inom ramen för handlingsprogrammet 2001-2004 samarbete om hållbart jordbruk, hållbart skogsbruk, genetiska resurser och biologisk mångfald,livsmedelssäkerhet och landsbygdsutveckling.

\section{Nordiska ministerrådet}

inrättades 1971 som ett samarbetsorgan mellan de nordiska ländernas regeringar. Ministerrådet lägger fram förslag till Nordiska rådets sessioner, vidarebefordrar rådets rekommendationer, rapporterar till Nordiska rådet om samarbetets resultat samt leder arbetet inom olika sektorer. Statsministrarna har ett överordnat ansvar för samarbetet, som i övrigt koordineras av samarbetsministrarna och den nordiska samarbetskommittén. Ministerrådet sammanträder i olika sammansättningar beroende på vilka frågor som skall behandlas.

\section{Nordiska rådet}

bildades 1952 som ett samarbetsorgan mellan parlamenten och regeringarna i Danmark, Island, Norge och Sverige. Finland anslöt sig 1955. Färöarnas, Grönlands och Ålands delegationer ingår i Danmarks respektive Finlands delegationer. Rådet består av 87 valda medlemmar (parlamentariker). Nordiska rådet är initiativtagare och rådgivande samt har kontrollerande och pådrivande uppgifter i det nordiska samarbetet. Nordiska rådets organ är plenarförsamlingen, presidiet och utskotten. 


\section{Forord}

Jordbrukets kulturlandskap er et produkt av nordisk jordbruk og landsbygder. Denne rapporten inneholder konkrete innspill for å styrke politikk og innsats for jordbrukets kulturlandskap i Norden. Den skal kunne brukes av politikere, forvaltning, fagmiljøer og organisasjoner som et fag- og idégrunnlag for å:

- utvikle nordiske og nasjonale anbefalinger $\mathrm{i}$ form av mål, strategier, tiltak og virkemidler innen jordbrukets kulturlandskap og dets natur- og kulturhistoriske verdier.

- gi anbefalinger om konkrete tiltak og oppfølging av disse i kulturlandskapet.

- gi anbefalinger for internasjonalt samarbeid innen dette tema i Norden.

- stimulere til erfaringsutveksling, nettverksbygging og tverrfaglig samarbeid i Norden.

- gi oversikt over nordiske arbeider og erfaringer innen dette tema.

En nordisk kulturlandskapskonferanse i Hordaland i Norge i juni 2003 med tittelen Landskapet som ressurs - Et samarbeid om utvikling av jordbrukslandskapets natur- og kulturhistoriske verdier i Norden" var en del av prosjektet. Konferansen med workshoper og erfaringer fra ekskursjonene er brukt som innspill til rapporten. Tema for workshopene var:

1. Politikk og overordna strategier

2. Nye næringer i landbruket med grunnlag i landskap, natur- og kulturhistoriske verdier

3. Kommunikasjon og motivasjon

4. Landbrukets rolle i lokal og regional samfunnsplanlegging

5. Kartlegging og overvåking

6. Natur- og kulturarv i særlig verdifulle områder

7. Utvikling av samarbeidet med de frivillige (ideelle) aktørene
Steinar Sørli, Fylkesmannen i Hordaland, Norge, var prosjektleder i 2003 med ansvar for gjennomføringen av konferansen. Rapporten er redigert av Anette Søraas med bistand fra Wenche Dramstad og Oskar Puschmann, begge Norsk institutt for jord- og skogkartlegging.

Styringsgruppa for prosjektet har bestått av: Anette Søraas, Landbruksdepartementet, Norge, (leder)

Anette Ginsbak, Skov- og naturstyrelsen, Danmark, Pertti Toivari, Jord- och skogsbruksministeriet, Finland, Audur Sveinsdottir, Landbruksuniversitetet Hvanneyri, Island Sofia Blom, Jordbruksverket, Sverige Lars Wilson, Riksantikvarieämbetet, Sverige, (rep NFK-gruppa)

Elisabet Haveraaen, Miljøverndepartementet, Norge, (observatør)

Prosjektet har vært finansiert med midler fra Nordisk miljøstrategigruppe for jord- og skogbruk (MJS), Fylkesmannen i Hordaland og Landbruksdepartementet i Norge. 


\section{Innhold}

Sammendrag, tiivistelmä, samantekt, summary

1 Innledning

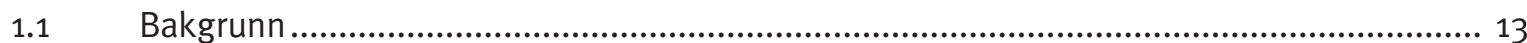

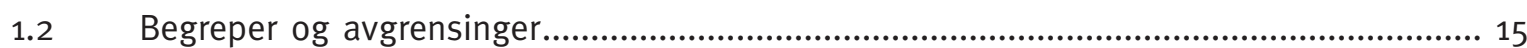

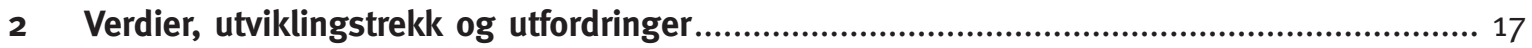

2.1 Verdien av jordbrukslandskapet og dets natur- og kulturhistoriske verdier ..................... 17

2.2 Rammevilkår og utviklingstrekk i samfunnet .................................................................... 19

2.3 Hovedtendenser $\mathrm{i}$ jordbruket og tilhørende utfordringer ............................................. 20

3 Mål og strategier for jordbrukslandskap i de nordiskelandene,

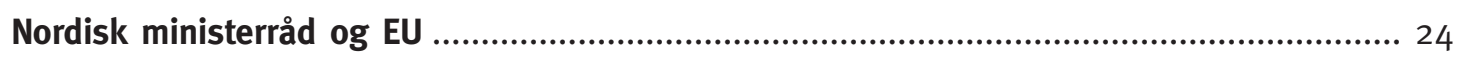

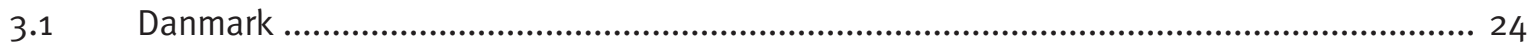

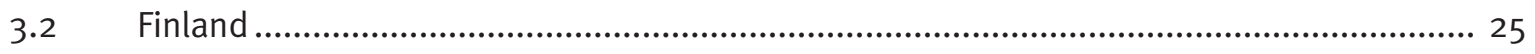

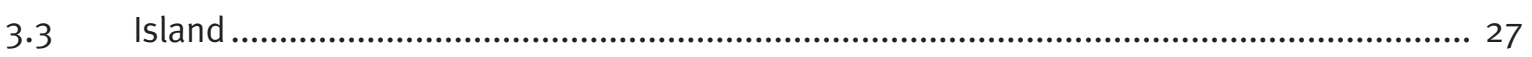

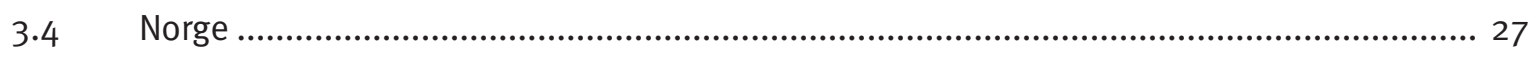

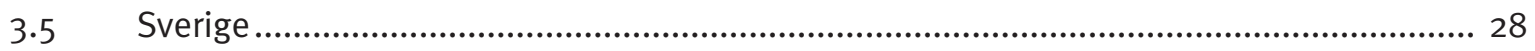

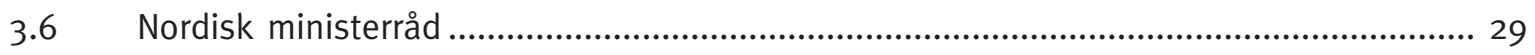

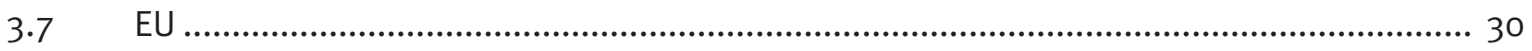

4 Hvordan nå miljø- og samfunnsmålene for jordbrukslandskap i Norden - erfaringer

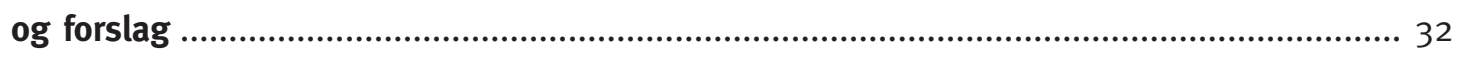

4.1 Overgripende politikk og prinsipper ......................................................................... 32

4.2 Jordbruk - landsbygd/ lokalsamfunn - deltakelse.......................................................... 37

4.3 Skjøtsel, vedlikehold og forvaltning av jordbrukslandskap ............................................ 44

4.4 Jordbrukslandskapet - grunnlag for næringsutvikling (og omvendt) ............................. 46

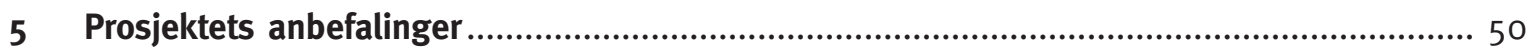

$6 \quad$ Litteratur og henvisninger ........................................................................................... 53

Vedlegg 1: Kulturlandskap i nordiske strategier og prosjekter ................................................... 55

Vedlegg 2: Et utvalg internasjonale konvensjoner, direktiver og avtaler.......................................60

Vedlegg 3: Samarbeid med ideelle organisasjoner og aktører ..................................................... 61 


\section{Sammendrag, tiivistelmä, samantekt, summary}

\section{Sammendrag}

\author{
Prosjektet "jordbrukslandskapet som ressurs" \\ anbefaler å styrke innsatsen for å ivareta jord- \\ brukets kulturlandskap i Norden ved å foreslå \\ mål, strategier og tiltak for nordisk samarbeid \\ og oppfølging i det enkelte land.
}

Nordisk samarbeid bør omfatte nettverksbygging og muligheter for erfaringsutveksling mellom landene og på tvers av fag og profesjoner. Det nordiske samarbeidet innen jordbruk bør omfatte jordbrukets kulturlandskap og jordbrukets rolle i landsbygdutvikling. Forslagene for det nordiske samarbeidet inkluderer å fremme jordbrukslandskap som et produkt av nordisk jordbruk i internasjonale sammenhenger og øke politisk fokus på jordbrukslandskapenes utvikling i Norden.

\section{Verdier og utfordringer (kap 2)}

Jordlandskap omfatter natur- og kulturhistoriske verdier og verdier knyttet til landskapet som en helhet. De nordiske jordbrukslandskapene gir mulighet for rekreasjon og opplevelser både for tilreisende og lokalsamfunnet. Den regionale variasjon i de nordiske jordbrukslandskapene gjenspeiler naturgrunnlag, kultur og bosetting, ulike produksjoner og eiendoms- og driftsstruktur i landbruket.

Utfordringene for å bevare og utvikle verdiene som en del av jordbruket i Norden, kan derfor være ulike fra land til land. Likevel er det mange felles utfordringer der landene har nytte av nordisk samarbeid.

Endringer i rammevilkår og samfunnsutvikling gir utfordringer for jordbruk, bosetting i lokalsamfunn og landsbygder i Norden, og dette gjenspeiler seg også i utfordringene for å ta vare på og skjøtte nordiske jordlandskap. Tendensene er både gjengroing, nedlegging av bruk, forfall og fraflytting, så vel som arealpress, intensivering og rasjonalisering $i$ jordbruket. Prosjektet har delt inn jordbrukslandskapene i tre hovedkategorier etter beliggenhet og tilhørende utfordringer:

1. Jordbrukslandskap i bygder preget av nedlegging $i$ jordbruket og fraflytting og med overskudd av bygninger, jordbruksareal og beiter.

2. Jordbrukslandskap med nærhet til by- og tettsted og attraktive friluftsområder.

3. Jordbrukslandskap i aktive, stabile jordbruksbygder, stor landbruksproduksjon.

Mål for jordbrukslandskap i de nordiske land, Nordisk ministerråd og EU (kap 3)

Alle de nordiske landene og EU har fastsatt mål som omfatter jordbrukslandskapets utvikling. Nordisk bærekraftstrategi, 2001-2004 inneholder nordiske mål og intensjoner for kulturlandskapet generelt, men det er ikke konkretisert mål og strategier for jordbrukslandskapet.

\section{Erfaringer og forslag (kap 4)}

Storsamfunnet er mange steder i ferd med å miste muligheter for å bruke jordbrukslandskapet som ressurs for befolkningen.

Befolkningen må derfor, i tråd med landskapskonvensjonen, gis mulighet til å påvirke og engasjere seg i hvordan jordbruket og jordbrukslandskapet skal utvikle seg.

Strategier og tiltak som stimulerer til et samarbeid og forståelse mellom ulike aktører er viktig. Disse er bl a: Jordbrukets egne aktører, 
lokalbefolkningen og allmennheten mer generelt, frivillige organisasjoner, forskningsinstitusjoner, offentlig forvaltning og aktører i andre næringer. Disse aktørenes rolle kan være å bidra til finansiering, fremme verdiskaping og deltakelse i beslutninger og konkret skjøtsel. Samtidig er de også kunder for produkter og brukere av jordbrukslandskapet.

Noen forutsetninger for å lykkes med satsinger på jordbrukslandskapet kan være å

- øke lokal forankring av jordbrukspolitikk og ansvar for kulturlandskap som kan skape engasjement $\mathrm{i}$ befolkningen. Et ledd i dette kan være å delegere beslutningsmyndighet til lokalt og regionalt nivå.

- prioritere verdifulle jordbrukslandskap som strategi for å sikre skjøtsel, og som grunnlag for areal- og samfunnsplanlegging.

- sikre aksept for jordbrukets produksjon av kollektive goder krever godtgjøring.

- verdiskaping med kulturlandskapet som grunnlag der en fremmer mangfold av verdier og kvaliteter. Dette skal øke produksjon av fellesgoder og gi alternative inntekstmuligheter lokalt.

Anbefalinger for en nordisk satsing (kap 5)

Anbefalingene er en prioritering av forslagene i denne rapporten og bygger på innspill fra nordisk kulturlandskapskonferanse i

Hordaland $i$ juni 2003. En anbefaling er at det bør utvikles en nordisk strategi for arbeidet med jordbrukets kulturlandskap. Anbefalingene inneholder også forslag til tiltak.

Forslag til mål:

Variasjonsrikdommen i jordbrukslandskapene i de nordiske landene med natur- og kulturhistoriske verdier skal ivaretas og vedlikeholdes $i$ et langsiktig perspektiv som en ressurs for samfunnet og for den nordiske identitet og utvikling.
Forslag til strategier:

1. De nordiske landene bør bidra til at jordbrukslandskapet og dets natur og kulturhistoriske verdier settes på dagsorden $\mathrm{i}$ internasjonalt samarbeid både faglig og politisk.

2. De nordiske landene bør arbeide for at internasjonale avtaler og -rammevilkår, gir frihet til å utforme en jordbrukspolitikk som bevarer det nordiske jordbrukslandskapet med levende lokalsamfunn, naturog kulturhistoriske verdier og andre kollektive goder.

3. De nordiske landene bør styrke arbeidet med informasjon, kommunikasjon, og kunnskapsutvikling om jordbrukslandskapets verdier og muligheter og søke å få en diskusjon i samfunnet om framtidas jordbrukslandskap.

4. Nordisk ministerråd og de nordiske land bør styrke fokus på jordbrukslandskapet som ressurs for identitet og trivsel og som potensial for nye næringer.

5. Nordisk ministerråd og de nordiske land bør bidra til at areal- og samfunnsplanlegging ivaretar helhetlige jordbrukslandskap $i$ et langsiktig perspektiv

6. Anbefalingene for jordbrukslandskap i tidligere nordiske rapporter bør videreføres. 


\section{Tiivistelmä (finsk)}

\section{Hanke "maatalousmaisema voimavarana" pyrkii vahvistamaan panostusta pohjoismaisen maatalouden kulttuuri- maiseman hoitoon ehdottamalla tavoitteet, strategiat ja toimenpiteet pohjoismaiselle yhteistyölle ja toiminnan seurannalle kussakin maassa.}

Pohjoismaisen yhteistyön tulee käsittää verkoston rakentaminen sekä mahdollisuudet kokemusten vaihtoon maitten ja eri toimialojen ja ammattiryhmien välillä. Pohjoismaisen yhteistyön maataloudessa tulee käsittää maatalouden kulttuurimaisema ja maatalouden rooli maaseudun kehittämisessä. Ehdotukset pohjoismaiselle yhteistyölle sisältävät maatalousmaiseman esille tuomisen kansainvälisissä yhteyksissä pohjoismaisen maatalouden tuotteena sekä poliittisen huomion lisäämisen maatalousmaisemien kehittämiseen pohjolassa.

\section{Arvot ja haasteet (luku 2)}

Maaseutumaisema käsittää luonto- ja kulttuurihistoriallisia arvoja sekä arvoja, jotka liittyvät maisemaan kokonaisuutena. Pohjolan maatalousmaisemat antavat mahdollisuuden virkistykseen ja elämyksiin sekä matkailijoille että paikalliselle väestölle. Alueellinen vaihtelu pohjolan maatalousmaisemissa heijastaa luontoperustaa, kulttuuria ja asutusta, erilaisia tuotantotapoja sekä varallisuutta ja elinkeinorakennetta maataloudessa.

Haasteet näiden arvojen säilyttämiseksi ja kehittämiseksi osana pohjoismaista maataloutta voivat siksi olla erilaiset eri maissa. Kuitenkin on monia haasteita, joissa maat hyötyvät pohjoismaisesta yhteistyöstä.

Reunaehtojen muuttuminen ja yhteiskunnan kehittyminen antavat haasteita pohjolan maataloudelle ja paikallisyhteisöjen ja maaseudun asutukselle, ja tämä heijastuu myös haasteena huolehtia ja hoitaa maaseutumaisemia pohjoismaissa. Kehityssuuntaukset ovat sekä umpeen kasvaminen, maatilojen lopettaminen, rapistuminen ja maaltamuutto että yhtä lailla myös alueiden tehokäyttö sekä maatalouden tehostuminen ja rationalisoituminen. Hanke on maatalousmaisemallisesti jaettu kolmeen pääkohtaan sijainnista ja siitä johtuvista haasteista riippuen:

1. Maatalousmaisemat seuduilla, joita luonnehtivat maatalouden loppuminen ja poismuutto ja joissa on rakennusten, maatalousmaan ja laitumien ylijäämää

2. Maatalousmaisemat lähellä kyliä ja taajamia ja houkuttelevia virkistysalueita

3. Maatalousmaisemat toimivilla, vakiintuneilla maatalousalueilla, joissa maataloustuotanto on merkittävää

\section{Tavoitteet maatalousmaisemille} pohjoismaissa, Pohjoismaiden ministerineuvostossa ja EU:ssa (luku 3)

Kaikki pohjoismaat ja EU ovat asettaneet tavoitteita koskien maatalousmaiseman kehittämistä. Pohjolan kestävän kehityksen strategia, 2001-2004 sisältää pohjoismaisia tavoitteita ja päämääriä kulttuurimaisemalle yleisesti, mutta ei sisällä maatalousmaisemaa koskevia konkretisoituja tavoitteita ja strategioita. 
JORDBRUKSLANDSKAPET SOM RESSURS I NORDEN

\section{Kokemuksia ja ehdotuksia (luku 4)}

Yhteiskunta on monin paikoin menettämässä mahdollisuuden käyttää maatalousmaisemaa voimavarana väestölleen. Väestölle tulee siksi, Euroopan maisemasopimuksen mukaisesti, antaa mahdollisuus vaikuttaa ja osallistua siihen, mihin suuntaan maatalous ja maatalousmaisema tulee kehittymään.

Strategiat ja toimenpiteet, jotka innostavat yhteistyöhön ja yhteisymmärrykseen eri toimijoiden välillä ovat tärkeitä. Näitä ovat $\mathrm{mm}$. maatalouden omat toimijat, paikallinen väestö, vapaaehtoisjärjestöt, tutkimuslaitokset, julkinen hallinto sekä toimijat muissa elinkeinoissa. Näiden osapuolien rooli voi olla avustaminen rahoituksessa, arvostuksen edistäminen ja päätöksentekoon osallistuminen sekä konkreettinen hoito. Samanaikaisesti ne ovat myös asiakkaita tuotteille ja maatalousmaiseman käyttäjiä.

Edellytykset onnistuneelle panostukselle maatalousmaisemaan ovat:

- maatalouspolitiikan paikallisen ankkuroinnin lisääminen ja vastuu kulttuurimaisemasta, jotka voivat luoda sitoutumista väestössä. Osana tätä voi olla viranomaispäätösten delegointi paikallis- ja aluetasoille.

- arvokkaiden maatalousmaisemien priorisointi hoidon varmistamisen strategiana ja perustana alue- ja yhdyskuntasuunnittelulle.

- hyväksynnän varmistaminen sille, että maatalouden julkishyödykkeiden tuottaminen vaatii tukemista.

- kulttuurimaiseman arvostaminen moninaisten arvojen ja laatuominaisuuksien edistämisen perustana. Tämä lisää erikoistuotteiden tuotantoa ja antaa vaihtoehtoisia tulomahdollisuuksia paikallisesti.

\section{Suosituksia pohjoismaiselle panostukselle (luku 5)}

Suositukset ovat priorisoitu tämän raportin ehdotuksista ja perustuvat Hordalandissa kesäkuussa 2003 pidetyn pohjoismaisen kulttuurimaisemakonferenssin ehdotuksiin. Yksi suositus on, että maatalouden kulttuurimaisematyöhön tulee kehittää pohjoismainen strategia. Suositukset sisältävät myös ehdotuksia toimenpiteiksi. Ehdotus tavoitteeksi:

Pohjoismaiden maatalousmaisemien luonnon- ja kulttuurihistoriallisten arvojen rikkaudesta ja vaihtelusta tulee huolehtia ja hoitaa niitä pitkällä tähtäimellä voimavarana yhteiskunnalle sekä pohjoismaiselle identiteetille ja kehitykselle.

\section{Ehdotukset strategioiksi:}

1. Pohjoismaiden tulee huolehtia, että maatalousmaisema ja sen luonto ja kulttuurihistorialliset arvot nostetaan esiin sekä ammatillisessa että poliittisessa kansainvälisessä yhteistyössä.

2. Pohjoismaiden tulee toimia siten, että kansainväliset sopimukset ja reunaehdot antavat vapauden muotoilla maatalouspolitiikkaa, joka säilyttää pohjoismaisen maatalousmaiseman elävine paikallisyhteisöineen, luonnon- ja kulttuurihistoriallisine arvoineen ja muine julkishyödykkeineen.

3. Pohjoismaiden tulee vahvistaa työtä maatalousmaiseman arvojen ja mahdollisuuksien tiedottamiseksi sekä tietojen vaihtamiseksi ja lisäämiseksi sekä pyrkiä saamaan yhteiskunnassa keskustelua aikaan tulevaisuuden maatalousmaisemasta.

4. Pohjoismaiden ministerineuvoston ja pohjoismaiden tulee vahvistaa huomion kohdentamista maatalousmaisemaan identiteetin ja viihtyisyyden voimavarana ja mahdollisuutena uusille elinkeinoille.

5. Pohjoismaiden ministerineuvoston tulee huolehtia, että alue- ja yhdyskuntasuunnittelussa otetaan huomioon maaseutumaisema kokonaisuutena pitkällä tähtäimellä.

6. Aikaisempien pohjoismaisten raporttien maatalousmaisemiin liittyviä ehdotuksia tulee toteuttaa. 


\section{Samantekt (islandsk)}

\author{
Í verkefninu ,jarđræktarlandslagiđ sem \\ auđlind" er mælst til pess ađ auka áherslu á \\ ađ vidhalda menningarlandslagi Norđurlanda, \\ međ pví ađ vinna ađ markmiđssetningu, \\ áætlunum og ađgerđum ađ norrænni \\ samvinnu ásamt eftirfylgni í hverju landi \\ fyrir sig.
}

Norræn samvinna verđur ađ fela í sér möguleika á netsamstarfi og miđlun á reynslu bæđi milli landa og einnig pvert á faghópa og störf. Norræna samvinnan innan jarđræktar (landbúnađar) fjalli ennfremur um menningarlandslag jarđræktar og hlutverk pess í byggđapróun. Tillögur um pá samvinnu verđi um ađ efla jarđræktarlandslag sem hluta af norrænni jarđrækt (landbúnađi) í alpjóđa samhengi og jafnframt ađ auka pólítíska sýn á próun jarđræktarlandslagsins á Norđurlöndum.

\section{Verđmæti og sóknarfæri (kafli 2)}

í jarđræktarlandslagi eru bæđi náttúru og menningarverđmæti auk landslagsverđmæta. sem Norrænt jarđræktarlandslag veitir möguleika á útivist og upplifun bæđi fyrir gesti og heimamenn. Fjölbreytileiki svæđa innan norræna jarđræktarlandslagsins endurspeglar náttúrufar, búsetu og mismunandi afurđvir auk eigna- og rekstrarforma innan landbúnađarins.

Sóknarfærin til ađ varđveita og próa áfram pau verđmæti sem eru hluti af hinu norræna jarđræktarlandslagi geta pess vegna veriđ mismunandi frá einu landi til annars. Samt sem áđur eru margir sameiginlegir snertifletir par sem löndin hafa gagn af norrænni samvinnu.
Á Norđurlöndum veita rammaskilyrđi og samfélagspróun aukin sóknarfæri innan jarđræktar, og búsetu í dreifbýli. Međ pví gefast möguleikar á ađ halda í og hirđa um jarđræktarlandslagiđ innan Norđurlanda.

Tilhneigingin er ađ land fari í órækt, búum sé brugđiđ, hnignun og brottflutningur íbúa, auk ásóknar í ađra landnýtingu, ofræktunar og hagræđingar.

I verkefninu er jarđræktarlandslaginu skipt í 3 ađalflokka eftir legu og áhersluatriđum:

1. Jarđræktarlandslagiđ í sveitum par sem landbúnađur er ađ leggjast af, brottflutningur íbúa - auđar bygginga, ónytjuđ ræktar- og beitilönd.

2. Jarđræktarlandslag í námunda viđ péttbýliđ og eftirsótt útivistarsvæđi

3. Jarđræktarlandslag par sem er stöđugleiki í atvinnu, mikil framleiđsla landbúnađarafurđa

\section{Markmiđ fyrir jarđræktarlandslag á Norđurlöndum, Norrænu ráđherranefndina og ESB (kafli 3) \\ Öll Norđurlöndinog ESB hafa ákveđin markmiđ sem fjalla um próun jarđræktar- landslagsins. \\ I Áætlun Norđurlanda um sjálfbæra próun 2001-2004 eru sameiginleg norræn markmiđ og fyrirætlanir almennt um menningarlands- lagiđ, en ekki bein markmiđ né áætlanir sérstaklega um jarđræktarlandslagiđ.}

\section{Reynsla og tillögur (kafli 4)}

Samfélagiđ sem heild er víđa fariđ ađ glata möguleikum á ađ nýta jarđræktarlandslagiđ 
sem auđlind fyrir íbúana. Íbúarnir verđa pess vegna, eins og getiđ er um í landslagsamningnum ađ fá tækifæri til ađ hafa áhrif á og taka pátt í pví hvernig landbúnađurinn og jarđræktarlandslagiđ próast. Áætlanir og ađgerđir sem hvetja til samvinnu ólíkra pátttakenda er mikilvæg: landbúnađargeirinn, heimamenn, opinberir ađilar og fulltrúar annarra atvinnugreina. Hlutverk allra getur veriđ ađ standa ađ fjármögnun, efla verđmætasköpun, eiga hlut ađ ákvarđanatöku og beinni umhirđu. Samtímis eru peir hinir sömu, neytendur afurđa og notendur ađ jarđræktarlandslaginu.

Eftirfarandi meginreglur og rammaskilyrđi ætti ađ leggja til grundvallar vinnu međ jarđræktarlandslagiđ;

- auka tengingu „,heim í hérađ” á landbúnađarpólítík og ábyrgđinni á menningarlandslagi, pannig ađ pađ höfđi til og efli áhuga íbúa. Leiđ til pess getur veriđ, ađ dreifa ákvörđunarvaldi til heimamanna og til sveitastjórna.

- forgangsrađa verđmætum svæđum jarđræktarlandslagsins međ áætlun sem tryggir umhirđu, og sem undirstöđu ađ skipulagsáætlunum

- tryggja viđurkenningu á pví ađ hlutdeild landbúnađarins í ađ skapa samfélagsgæđi krefst endurgjalds

- próa óhefđbundna tekjumöguleika - til ađ tryggja umhirđu verđmætra svæđa. Ađgerđir sem hvetja fleiri til pátttöku, geta stuđlađ ađ fleiri fjármögnunarmöguleikum.

\section{Mælt er međ norrænum ađgerđum (kafli 5)}

Mælt er međ pví ađ forgangsrađa tillögunum sem fjallađ er um í pessari skýrslu, par sem m.a. er byggt á efni frá norrænu menningarlandslagsráđstefnunni î Hordalandi i júní 2003.

Ein af tillögunum er sú ađ pađ ætti ađ próa norræna ađgerđaáætlun ađ vinnu međ menningarlandslag jarđræktarbúskaparins. Lagđar eru fram tillögur ađ ađgerđum.
Tillögur ađ markmiđum:

Langtímamarkmiđ skal vera pađ ađ halda utan um og viđhalda fjölbreytileika jarđræktarlandslagsins innan Norđurlanda par sem verđmæti náttúru- og menningarminja eru auđlegđ fyrir samfélagiđ og fyrir hina norrænu sérstöđu og próun.

\section{Tillögur ađ ađgerđum:}

1. Norđurlöndin stuđli ađ pví ađ náttúru- og menningarverđmæti jarđræktarlandslagsins verđi sett á dagskrá í alpjóđa samvinnu bæđi á faglegum og pólítískum vettvangi

2. Norđurlöndin vinni ađ pví ađ alpjóđasamningar og rammaskilmálar, gefi svigrúm til ađ móta landbúnađarpólítík sem verndar hiđ norræna jarđræktarlandslag - par sem eru „, lifandi sveitir”, náttúru- og menningarminjar og önnur samfélagsgæđi

3. Norđurlönd efli upplýsingar, pekkingu og samskipti á verđmætum og möguleikum jarđræktarlandslagsins - ásamt pví ađ koma af stađ umræđu í samfélaginu um jarđræktarlandslag framtíđarinnar

4. Norræna ráđherranefndin og Norđurlöndin styrki pá sýn ađ jarđræktarlandslagiđ sé auđlegđ ađ samsömun og vellíđan íbúanna og sem hvati nýrra atvinnutækifæra

5. Norræna ráđherranefndin og Norđurlöndin vinni ađ pví ađ í byggđa- og skipulagsáætlunum verđi tekiđ tillit til og fjallađ um jarđræktarlandslagiđ sem heild og sem framtíđarsýn.

6. Fylgt verđi eftir pví sem pegar hefur veriđ mælt međ í fyrri áætlunum og norrænum skýrslum. 


\section{Summary}

\section{The project "Agricultural landscapes as a resource" recommends strengthening the effort to preserve agricultural landscapes in the Nordic countries and suggests aims, strategies and measures for cooperation and follow-up in the Nordic countries.}

Nordic collaboration should include establishment of networks and possibilities for exchange of experience between countries and across academic disciplines and professions. Nordic cooperation within agriculture should address issues concerning agricultural landscapes and the role of agriculture in rural development. Suggestions for such Nordic cooperation include the promotion in international fora of agricultural landscapes as a product of Nordic agriculture and a strengthening of the political focus on the development of agricultural landscapes in the Nordic countries.

\section{Values and challenges (chp 2)}

Agricultural landscapes include a wealth of natural and cultural history qualities as well as the value of the landscape as a whole. Nordic agricultural landscapes provide opportunities for recreation and outdoor experiences both for tourists and the local population. Regional differences between agricultural landscapes in the Nordic countries reflect differences in natural conditions, culture and settlement patterns, and different structures related to production, ownership and agricultural management.

The challenges involved in preserving and developing these qualities and values as a part of Nordic agriculture can differ between countries. However, there are a number of common challenges where countries can benefit from Nordic collaboration.

The socio-economic conditions and development of society represents challenges to agriculture, and to rural development within the Nordic countries. This is also reflected in the difficulties involved in preserving and managing agricultural landscapes in the Nordic area. Trends include abandonment of farms, reforestation, the neglect and disrepair of buildings and infrastructure and the emigration of people from rural areas, as well as land use conflicts and the intensification and rationalisation of agriculture. The project has divided agricultural landscapes into three categories, depending on location and main challenges;

- Agricultural landscapes in rural areas dominated by agricultural abandonment and rural emigration, resulting in a surplus of buildings, agricultural area and grassland.

- Agricultural landscapes which are near urban areas and areas attractive for recreation.

- Agricultural landscapes in active and stable agricultural areas with high agricultural production.
Aims for agricultural landscapes in the Nordic countries, the Nordic Council of Ministers and the EU (chp 3)
All the Nordic countries and the EU have established objectives that incorporate issues related to the development of agricultural landscapes. The Nordic Strategy for a Sustainable Development, 2001-2004, includes Nordic aims and intentions for cultural landscapes in general, but there are no explicit aims and strategies for agricultural landscapes. 


\section{Experiences and suggestions (chp 4)}

Society in general is, in many places, about to lose the potential of using agricultural landscapes as a resource for the public. The public should therefore, in accordance with the landscape convention, be provided the opportunity to affect and be involved in how agriculture and agricultural landscapes shall develop.

Strategies and measures that stimulate collaboration between different stakeholders are important; including people involved with agriculture, local inhabitants, public authorities and stakeholders representing other businesses. The role of these stakeholders can be to contribute to financing and participation in local governance and land management activities. At the same time they represent customers for products, and users of agricultural landscapes.

Some conditions for success with actions in agricultural landscapes could be to:

1. increase local relevance of agricultural policy and local responsibilities for agricultural landscapes that can involve local inhabitants. One aspect of this might be to delegate decision-making authority to local and regional levels.

2. prioritise valuable agricultural landscapes as a strategy to ensure appropriate land management, and as a basis for land use and societal planning.

3. gain acceptance for the principle that agriculture's production of public goods requires financial support.

4. develop alternative income options - to ensure management of important qualities. Measures involving a wide range of stakeholders can also give rise to more opportunities for funding.

\section{Recommendations (chp 5)}

The recommendations are prioritised suggestions from this report and are based on input from the Nordic conference on agricultural landscapes in Hordaland June 2003. One recommendation is that a Nordic strategy for working with agricultural landscapes should be developed. The recommendations also include suggested measures for action.

\section{Suggested aim:}

The wealth of variety in the agricultural landscapes of the Nordic countries, including associated natural and cultural history qualities, shall be preserved and managed in a longterm perspective as a resource for society and for the Nordic identity and development.

\section{Suggested strategies:}

1. The Nordic countries should contribute towards putting agricultural landscapes and their natural and cultural history values on the agenda in international collaborations, both academic and political.

2. The Nordic countries should collaborate to make sure international terms and agreements, provide freedom to develop an agricultural policy which preserves the Nordic agricultural landscapes, with active rural societies, natural and cultural heritage and other public goods.

3. The Nordic countries should strengthen work with information, communication and knowledge development regarding the qualities and opportunities inherent in agricultural landscapes and aim to establish a public debate on agricultural landscapes of the future.

4. The Nordic council of ministers and the Nordic countries should strengthen their focus on agricultural landscapes as a source of identity and enjoyment, and a source of potential new economic enterprises.

5. The Nordic council of ministers and the Nordic countries should contribute to a land use planning that takes account of entire agricultural landscapes in a longterm perspective.

6. Actions should be taken to follow up recommendations regarding agricultural landscapes that have been expressed in previous Nordic reports. 


\section{Innledning}

\subsection{Bakgrunn}

Gjennom århundrene har jordbrukslandskapet hatt som hovedfunksjon å være grunnlag for matproduksjon og har derved vært avgjørende for liv og helse. Nå vektlegges i økende grad også jordbrukslandskapets betydning som nærmiljø, som skaper av tilhørighet, som arealer for opplevelse av lokal natur og kultur, som historisk dokumentasjon, som kilde til rekreasjon og friluftsliv, og som ressurs for nyskaping.

Landene i Norden har stort mangfold og variasjon i jordbrukslandskap og natur- og kulturhistoriske verdier. Mange områder er godt vedlikeholdt, og skjøttes i stor grad gjennom jordbruksdrift eller ved en nær kobling mellom aktive bruk og aktivt deltagende bygdesamfunn. Et miljøvennlig og bærekraftig jordbruk med en variert bruksstruktur gir et jordbrukslandskap med et vidt spekter av plante og dyrearter, stier og veifar og kulturmiljøer som et tilleggsprodukt av jordbruksdrifta.

Endringer er en del av jordbrukslandskapets historie, men de raske endringene i jordbruksproduksjon og bruksstruktur som skjer i flere av de nordiske landene, kan føre til at mange av de positive tilleggseffektene kan bli truet. Endringer i jordbruket, som ofte gjen-

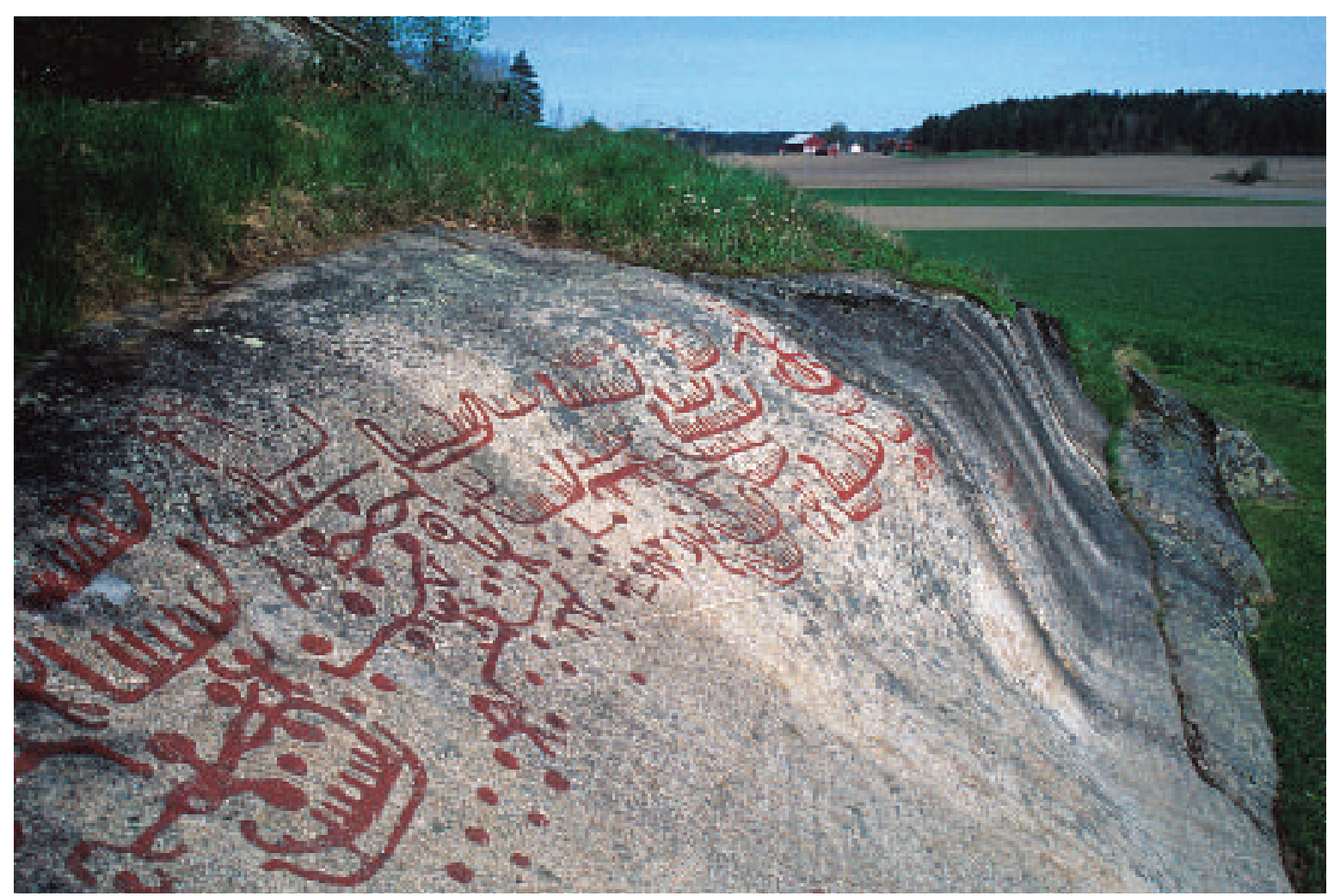

Menneskets bruk av naturen gjennom flere tusen år har bidratt til å forme kulturlandskapet, slik disse hellristningene illustrerer. Bonden er en viktig forvalter av dette landskapet. Foto: Oskar Puschmann, NIJOs. 

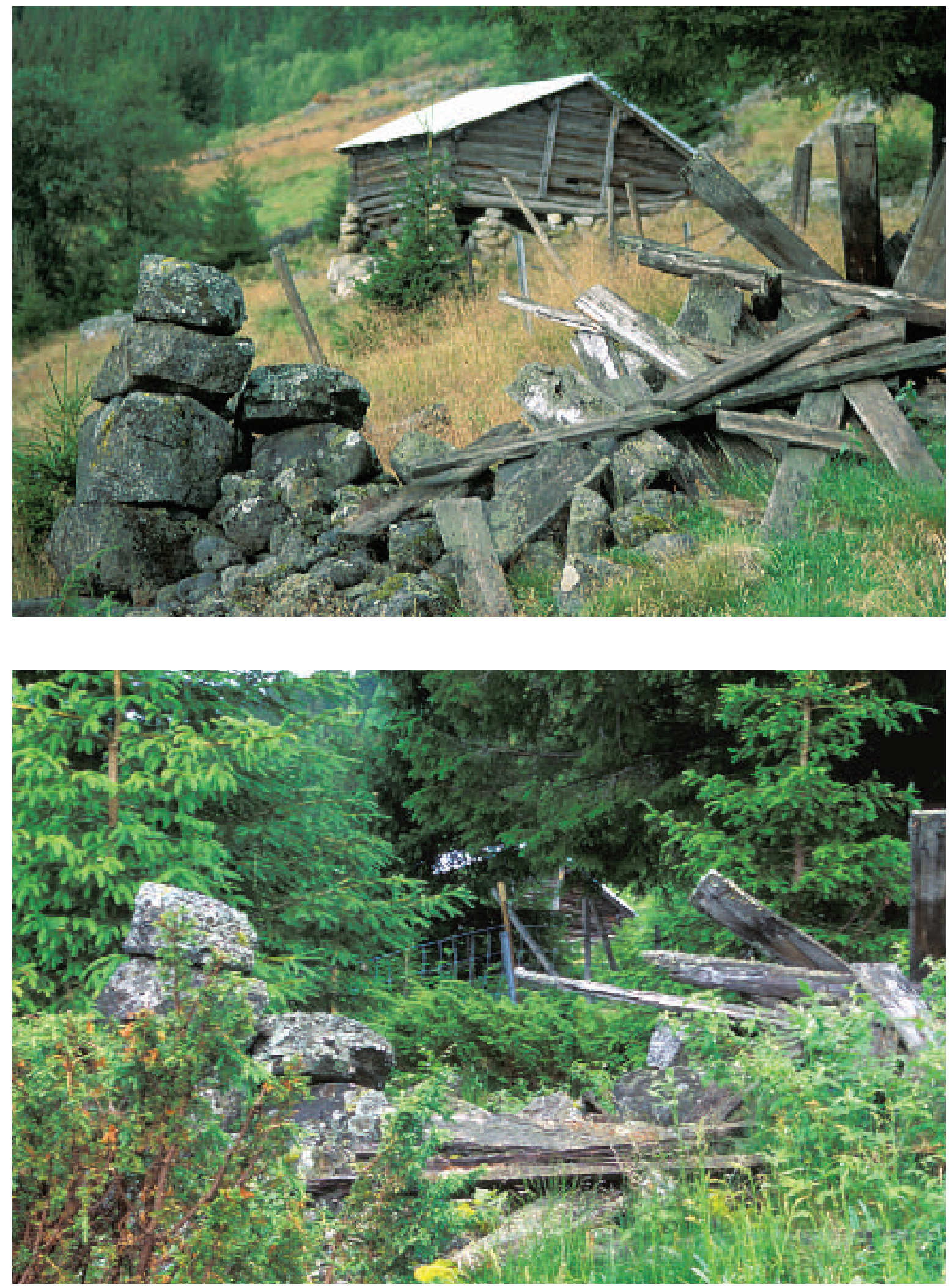

Gjengroing rundt gamnelt vårfjøs, 1992 øverst og 2002 nederst. Hva ønsker folk flest for jordbrukspolitikk og utviklingen i landskapet? Foto: Oskar Puschmann, NIJOs. 
speiles som endringer i kulturlandskapet, påvirkes også av generelle endringer ellers i samfunnet og markedet for jordbruksprodukter, jf kap 2. De positive effektene av jordbruksproduksjonen må tas særskilt hensyn til i utforming av politikk og virkemidler. De nærmeste årene bør bære preg av handling, dersom vi ønsker å satse på jordbrukslandskap som gode for befolkningen.

De store forskjellene mellom landskapene og jordbruket i de nordiske landene innebærer at vilkårene for å utvikle og bevare lokalsamfunn og kulturlandskap også er ganske ulike. Videre er det forskjeller på jordbrukets omdømme i befolkningen, og jordbrukets rolle i produksjon av miljøgoder. Dette kan ha betydning for samfunnets betalingsvillighet og engasjement både innen og mellom de ulike nordiske land.

Men jordbrukslandskapets funksjoner gjør det til en ressurs i distrikts- /landsbygdsutvikling og verdiskaping. Dette er et viktig felles utgangspunkt for samarbeid i Norden.

I de nordiske land er det mange mennesker som bor eller bruker mye av fritiden $\mathrm{i}$ jordbrukslandskapet, og utviklingen i jordbrukslandskapet er viktig for samfunnet. Men en $ø$ kende urban befolkning kjenner ikke nødvendigvis sammenhengen mellom jordbruksproduksjon og det kulturlandskapet de opplever. $\AA$ fremme et økt tilbud til befolkningen i jordbrukslandskapet, kan forbedre denne kontakten med jordbruket.

\subsection{Begreper og avgrensinger}

I den europeiske landskapskonvensjonen defineres landskap slik: "Landscape is defined as a zone or area as perceived by local people or visitors, whose visual features and character are the result of the action of natu- ral and/or cultural (that is, human) factors. This definition reflects the idea that landscapes evolve through time, as a result of being acted upon by natural forces and human beings. It also underlines that landscape forms a whole, whose natural and cultural components are taken together, not separately." På norsk, i kortversjon: "Landskap betyr et område slik folk oppfatter det, hvis særpreg er et resultat av påvirkningen fra og samspillet mellom naturlige og/eller menneskelige faktorer." 1

Begrepene landbrukets kulturlandskap, jordbrukets kulturlandskap og jordbrukslandskap, kan ha noe ulikt innhold $\mathrm{i}$ de nordiske landene, på grunn av ulike naturgitte og kulturelle forhold. I Sverige, Norge og Finland er landbrukets kulturlandskap et vidt begrep som omfatter de jordbrukspåvirkede områder i inn- og utmark, skogbrukets kulturlandskap og reindriftens og samiske kulturlandskap i tillegg til tun- og hagebruk. I Danmark brukes oftest begrepet jordbrukslandskap, og områder der det er etablert skog kan inngå $\mathrm{i}$ dette. I Island brukes begrepet landbrukets kulturlandskap, og det omfatter også områder der det etableres skog.

Jordbrukets kulturlandskap er en del av det som kan inngå i landbrukets kulturlandskap. Dette er områder der jordbruksproduksjon setter et preg på landskapet i form av kulturhistoriske-, økologiske/biologiske-, estetiskeog immaterielle kvaliteter. Der hvor befolkningen tradisjonelt har drevet mange ulike næringer (mangesysleri) i tilknytning til jordbruket, setter dette sitt preg på landskap, bygninger og anlegg. Områder preget av slike kombinasjonsnæringer kan også utgjøre en naturlig del av jordbrukets kulturlandskap, eks jordbruk i kombinasjon med skogbruk, fiske, utmarksnæring eller småindustri og håndverk.

1 Nordens landskap, forprosjekt for oppfølging av den europeiske landskapskonvensjonen, TemaNord 2003:550 


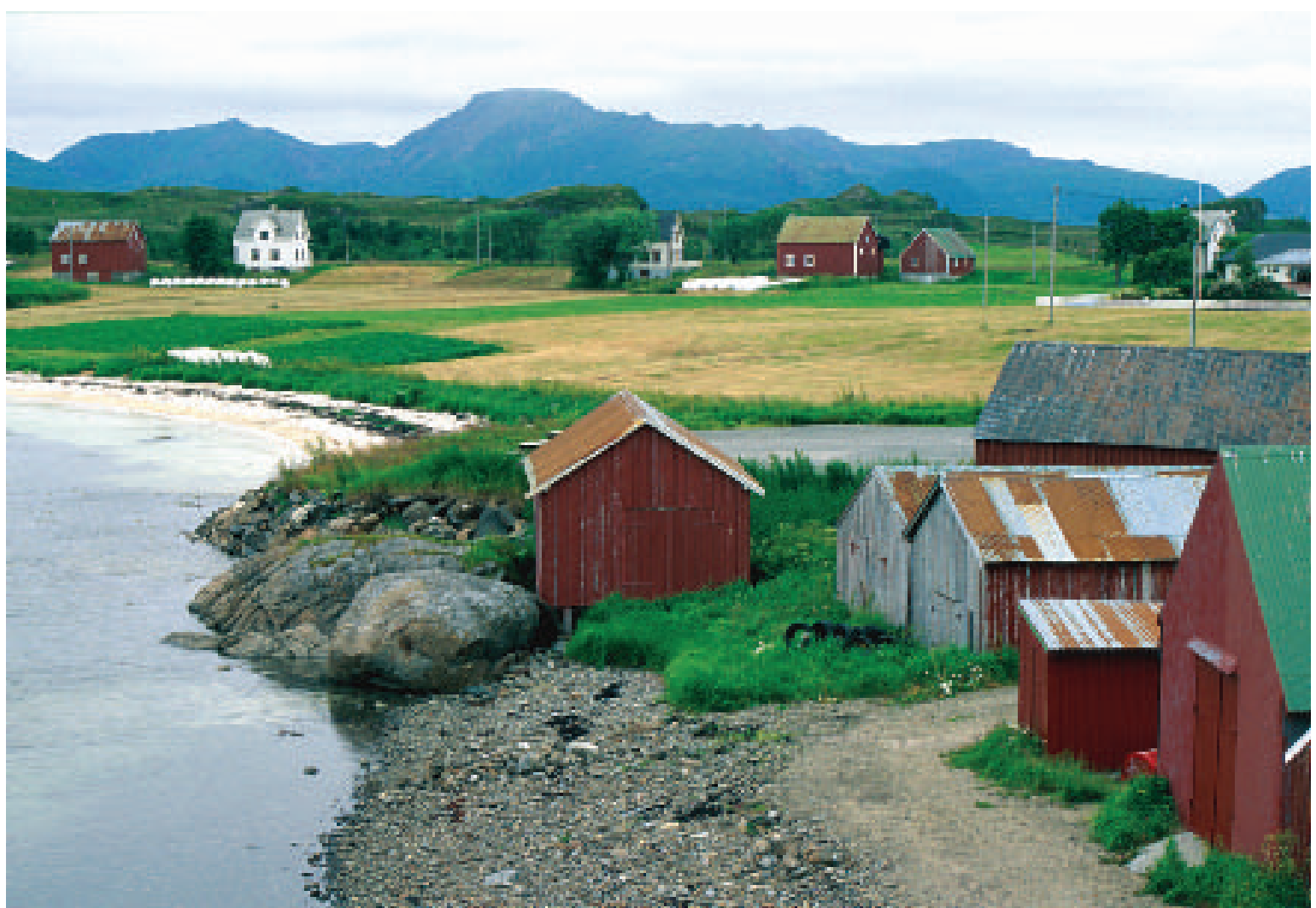

Kombinasjon av jordbruk, fiske, skogbruk eller småindustri har vært utbredt i alle de nordiske landene. Bildet viser fisker- og bondefamiliens båtnaust mot gårdstun og innmark. Foto: Oskar Puschmann, NIJOs.

Denne rapporten har fokus på jordbrukslandskap inkludert arealer med spor etter jordbruksdrift i utmark. Landskap knyttet til skog, fiske og andre landbrukstilknyttede næringer tas med i den grad det er viktig for helheten. Videre i denne rapporten er begrepene kulturlandskap og jordbrukslandskap brukt synonymt. 


\section{Verdier, utviklingstrekk og utfordringer}

Når det gjelder jordbrukslandskap, jordbruk og landsbygder, er det er til dels svært ulike utviklingstrekk, naturgitte forutsetninger og kultur i de nordiske landene. Likevel er det mange likhetstrekk som gjør at en kan peke på flere felles utfordringer og muligheter.

I denne rapporten er det ikke gitt spesifikke beskrivelser av status og utfordringer fra hvert av de nordiske landene. Dette blir i større grad presentert i det nordiske prosjektet "Landbrukets fremtida rolle" som har gått parallelt med dette prosjektet. Det finnes også utfyllende nasjonale landskapsbeskrivelser $\mathrm{i}$ flere nordiske arbeider ${ }^{2}$.

\subsection{Verdien av jordbrukslandskapet og dets natur- og kulturhistoriske verdier}

Ulike natur- og samfunnssyn kan ligge til grunn for diskusjoner om landbrukets betydning og jordbrukslandskapets verdi. Det har tradisjonelt vært klare skiller mellom de humanistiske- og de naturvitenskapelige miljøene innen forskning og forvaltning i måten å betrakte naturen på og menneskets plass $\mathrm{i}$ dette, dvs om mennesket eller naturen settes i sentrum. Innen jordbruket har man tradisjonelt fokusert på natur som et objekt for menneskelig utnyttelse, og i mindre grad fokusert på naturens egenverdi som ofte har vært det rådende synet innen tradisjonelt naturvern. Forskjeller i verdisyn og perspektiv kan også ha betydning for hvilke verdier man ser $\mathrm{i}$ jordbrukslandskapet, og det vil påvirke begrepsbruk og syn på virkemidler.
Kulturelle forskjeller både innen og mellom land kan også ha betydning for verdsetting av landskapet. Endringer i samfunnet, blant annet gjennom økt grad av urbanisering, økt velferd og økt internasjonal kontakt fører også til kulturelle endringer. Storsamfunnets behov, forventninger og syn på jordbruk, lokalsamfunn og landskapsverdier forandrer seg. Vi kan forvente at framtidens befolkning vil gjøre andre prioriteringer enn dagens og gårsdagens befolkning.

Når det gjelder ressurser og verdier knyttet til jordbrukslandskapet i Norden, brukes ulike inndelinger. Følgende sammenstilling illustrere omfang og bredde:

Menneskene i landskapet fremheves bl.a. i Den europeiske landskapskonvensjonen I dette ligger en erkjennelse av verdien knyttet til menneskers kunnskap og kompetanse, samt den betydningen jordbrukslandskapet har som et fundament for sosial tilhørighet og en arena som knytter mennesker sammen. Dette berører både bønder og befolkningen ellers.

Inndeling av verdier i landskapet etter i ulike kriterier, modifisert etter NMR 1987-3 3

1. Eksistens og egenverdi

- verdi for identitet og trivsel, kultur, tradisjon

- økologisk funksjon

- kunnskaps- og pedagogisk verdi

Kriterier for verdi av landskap, biologisk

2 Jordbrukets fremtida roller, NMR 2004(i trykk), Nordens landskap, forprosjekt for oppfølging av den europeiske landskapskonvensjonen, TemaNord 2003:550, Jordbrukslandskapets kulturverdier, TemaNord 2000:520 og Nord 2000:18.

3 Nordisk ministerråd miljørapport 1987:3 Natur-og kulturlandkspaet $i$ arealplanleggingen 2. Forvaltning av ressurser og verdier 
mangfold og kulturmiljøer er bl a:

Representativitet mht til mangfold, sjeldenhet, estetikk/ landskapsbilde/helhet, egenverdi, intensitet, kontinuitet/vedlikehold.

Stedsavhengige verdier $i$ arealer og landskap Landskapets helhet, estetiske kvaliteter og historiske tidsdybde: er forhold av betydning for de verdier jordbrukslandskapet har. Det visuelle åpne landskapet, med sin lokale variasjon og de enkeltelementer som trer fram, er noe mange verdsetter.

Biologiske mangfold og de biologiske systemene knyttet til både gammel kulturmark med lang kontinuitet og biotoper/naturtyper/ arter/genressurser som er knyttet til jordbrukslandskapet. Det karakteristiske for jordbrukslandskapet er at påvirkningen fra både mennesker og beitedyr kan ha pågått i flere tusen år. Mange av naturtypene og økosystemene i jordbrukslandskap er derfor kulturbetingete, dvs at det er en gjensidig avhengighet mellom tradisjonelle driftsformer og plante og dyreliv.

Kulturhistoriske verdier: Jordbrukslandskapet har ofte et bredt spekter av kulturminnerfra ulike tidsperioder: Fornminner fra forhistorisk tid, landbrukets bygningsarv og tun- og bosettingsstruktur. Bygge- og driftsmetoder med lange tradisjoner har også verdi. De kulturhistoriske verdiene omfatter både materielle og immaterielle verdier.

\section{Bruksinteresser}

- verneinteresser

- landbruk, utmarksnæring og andre næringsinteresser
- friluftsliv og rekreasjon

- utbyggingsinteresser

3. Opsjonsverdi (mulig framtidig verdi) Føre-var-prinsippet er sentralt i Konvensjonen om bærekraftig utvikling og konvensjonen om biologisk mangfold og skal sikre at fremtidens befolkning får mulighet til å dekke sine behov.

Begrepene kollektive og private goder brukes i økonomisk terminologi, gjerne knyttet til drøfting av ulike virkemidler og grad av kobling ("jointness") mellom produksjon av varer og kollektive goder. Private goder er varer og tjenester som lar seg omsette i et marked, mens helt kollektive goder vanskelig lar seg omsette. Kollektive goder karakteriseres både av at et individs bruk ikke innskrenker et annet individs mulighet for å bruke godet og at det ikke er mulig å ekskludere noen fra å bruke varen ${ }^{4}$. Produsenter av kollektive goder får derfor ikke betalt for godet og brukeren får ikke gitt sin "stemmeseddel" i markedet som kunne gitt godet en verdi. Mange miljøverdier er kollektive goder. Jordbrukslandskapet, biologisk mangfold, kulturmiljøer, levende bygder $\mathrm{mm}$ kan oftest ikke omsettes i markedet, og er derfor eksempler på kollektive goder.

Det finnes metoder for å sette verdi på kollektive goder direkte eller indirekte 5. Å kvantifisere denne type verdier er gjenstand for diskusjon, både i vitenskaplige miljøer og ellers i samfunnet. I Norge er slike metoder brukt i forbindelse med konsekvensutredning. er etter Plan- og bygningsloven. Internasjonalt finnes eksempler på at slik

4 Erik Fahlbeck, Sveriges lantbruksuniversitet, 4/7-03: Innlegg på det nordiske seminaret "Jordbrukets fremtida roller", Sigtuna, Sverige

5 Navrud, S. 2002 Overview of indicators on the valuation of agricultural landscapes. I NIJOS rapport 07/2003

Navrud, S. 2000 Valuation techniques and benefit Transfer Methods: Strengths, weaknesses and Policy Utility. I OECD, 2000

NOU 1998:16 Nytte-kostnadsanalyser. Veiledning i bruk av lønnsomhetsvurderinger i offentlig sektor

NOU 1997:27 Nytte-kostnadsanalyser. Prinsipper for lønnsomhetsvurderinger i offentlig sektor 


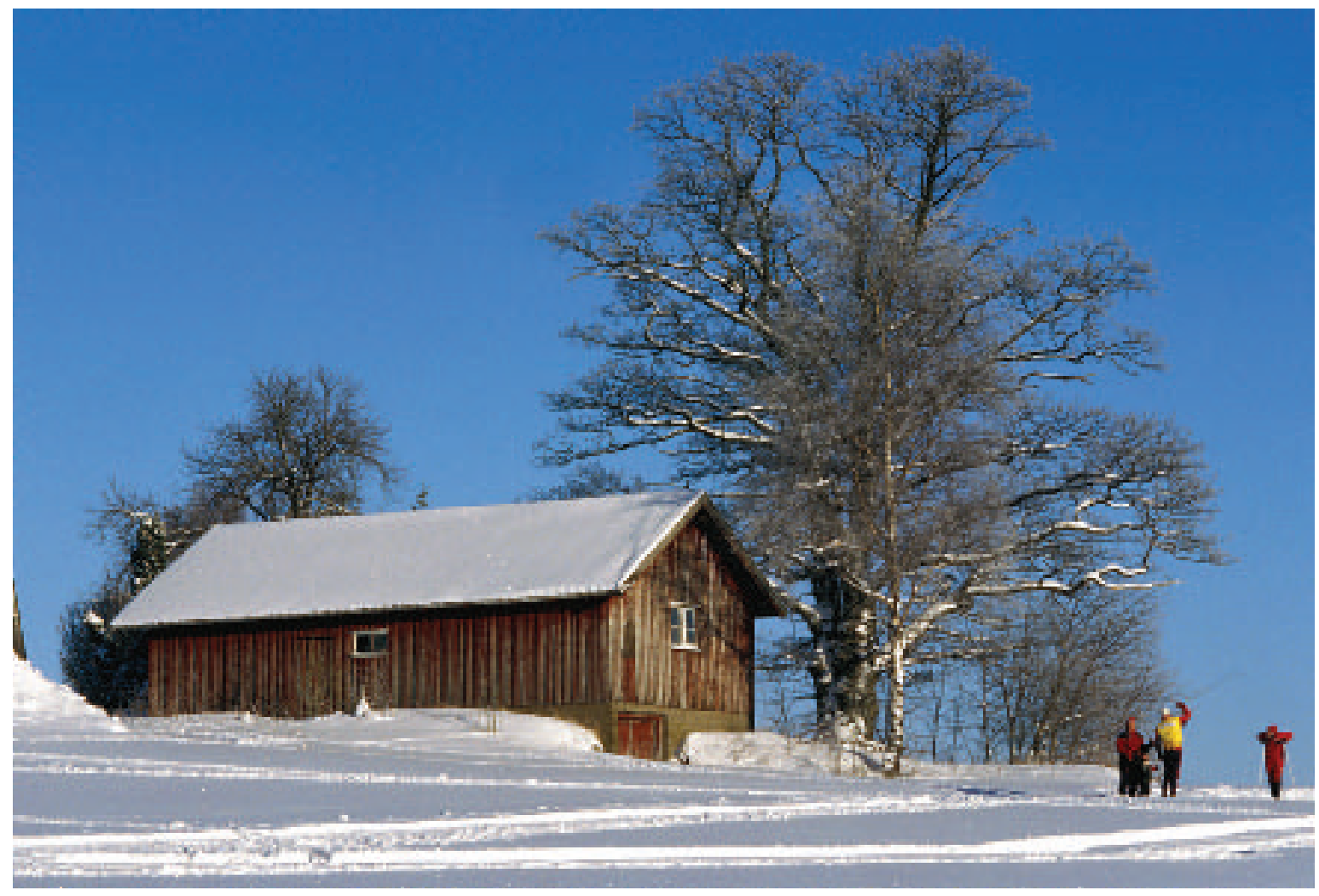

I Den europeiske landskapskonvensjonen framheves menneskene i landskapet. Landskapet knytter menneskene sammen. Landskapet, kulturminner, plante- og dyreliv forsterker opplevelsene vi har sammen.

Foto: Foto: Oskar Puschmann, NIJOs.

verdisetting er lagt til grunn for forsikringsoppgjør etter miljøkatastrofer. Felles for disse eksemplene er at de tar utgangspunkt i et konkret område og konkrete endringer. Jordbrukslandskapets verdi for samfunnet kan også uttrykkes gjennom de beslutninger som gjøres i demokratiske prosesser. En rekke internasjonale avtaler og konvensjoner (se vedlegg) kan også ses som et uttrykk for verdien av biologisk mangfold, bærekraftig utvikling, landskap og natur- og kulturmiljøer.

\subsection{Rammevilkår og utviklingstrekk i samfunnet}

Tre kategorier av rammevilkår og utviklingstrekk i samfunnet har særlig betydning for jordbrukslandskapets utvikling:

1. Internasjonale rammevilkår som økonomiske konjunkturer, trender og utviklingen av internasjonale avtaler og konvensjoner for bl a handel (eks EU/EØS, WTO) og miljø- vern/ bærekraftig utvikling (vedlegg 2).

2. Nasjonale, regionale og lokale rammevilkår og samfunnsutvikling har betydning for hvordan landskapet vil se ut i framtiden. $\mathrm{F}$ eks utviklingen i distriktene/landsbygdene og bosettingsmønster, inntektsutviklings- og sysselsettingsmuligheter og levekår, både innen landbruket, i lokalsamfunnet og i samfunnet ellers.

3. Rammevilkår innenfor landbruket knyttet til effektivisering, strukturutvikling, eierforhold, rammevilkår for dyrehold og beitebruk $\mathrm{mm}$.

De faktorene som påvirker utviklingen i selve landskapet mest direkte er blant annet:

a) Samfunnets arealplanlegging og arealforvaltning,

b) Landbrukspolitikk og driftsformer i landbruket (skjøtsel, husdyr/beitebruk) samt markedet for jordbruksvarer,

c) Bosetting/landsbygdsutvikling 


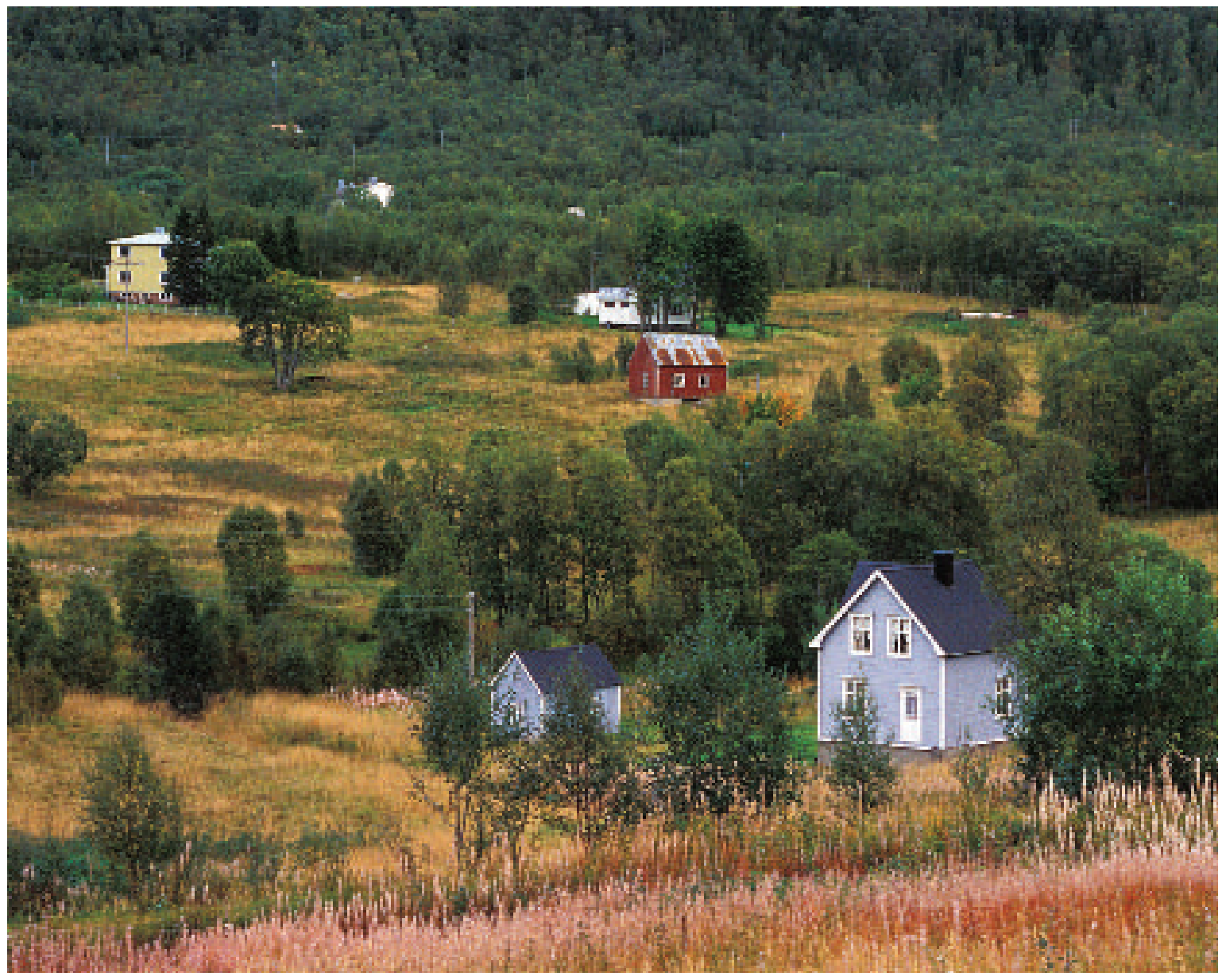

Stadig flere jordbruksbygder opplever betydelig nedgang i aktive gårdsbruk. Mest bekymringsfullt er det i bygder hvor "den siste brukeren" gir seg, dvs. bonden som leide og skjøttet de øvrige nedlagte gårdenes jordbruksmark. Når det skjer, gror "alt" igjen. Foto: Oskar Puschmann, NIJOs.

d) Bøndenes kunnskaper, holdninger og innsats.

e) Den øvrige befolkningens kunnskaper, engasjement og innsats i kulturlandskapet

Kulturlandskapet har alltid endret seg i takt med rammevilkår og samfunnsutvikling. Et sentralt spørsmål er om en ønsker å påvirke retningen og sette mål for utviklingen, og hvilke muligheter som eventuelt finnes for å kunne påvirke. Flere av de nordiske landene har satt mål for både miljø og landbruk som omfatter kulturlandskapet, jf kap 3. Dette er et uttrykk for at landskapsutvikling er viktig for samfunnet. Et langsiktig nordisk mål for utviklingen i jordbrukets kulturlandskap er foreslått i anbefalinger i kap 4.

\subsection{Hovedtendenser i jordbruket og tilhørende utfordringer}

Jordbruket har hatt stor betydning for utformingen av landskapene i Norden. I dag følger utviklingen i jordbruket i Norden særlig tre hovedtendenser:

- Mange jordbruksområder er sterkt preget av nedlegging, gjengroing og forfall. Noen steder skjer også omdisponering til nye formål, f.eks til områder for fritidshus.

- Andre jordbruksområder er sterkt preget av rasjonalisering og intensivering eller rask endring av jordbruksdriften, og eventuelt også press fra by- og tettstedsvekst.

- "Stabile" jordbruksområder

Den første tendensen vurderes som den mest 
akutte; i store deler av Norge, Sverige, Finland og til dels Island, selv om gjengroing ikke er en utfordring på Island. Mange steder har dette klar sammenheng med rasjonalisering og nedgang $\mathrm{i}$ antall bruk i drift. Det er likevel usikkert hvordan jordbruket og jordbrukslandskapet kunne ha utviklet seg i disse områdene uten en rasjonalisering. Særlig i de senere tiår er antallet driftsenheter redusert betydelig i de nordiske land. Utviklingen $\mathrm{i}$ rammebetingelser og internasjonale prosesser vil trolig bidra til at antall driftsenheter reduseres ytterligere.

En forståelse av hvilke krefter som virker på et landskap, kan bidra til en forståelse av hva en forvaltningsstrategi bør fokusere på for å møte utfordringene og mulighetene de enkelte landskap og lokalsamfunn står overfor. I denne sammenheng kan det være interessant å dele inn jordbrukslandskapene basert på tendenser/viktige trekk på et regionalt nivå. En slik inndeling følger nedenfor, og utfordringer skisseres for hver av dem:

1. Kulturlandskap i bygder preget av nedlegging $i$ jordbruket og eventuelt fraflyttes og områder med overskudd av bygninger, jordbruksareal og beiter.

Utfordringer:

i Sikre alternativ bruk og jordbruksdrift av området som kan motvirke nedlegging, gjengroing og forfall og videreføre biologiske verdier og kulturarv

ii Tap av interesserte ressurspersoner eller organisasjoner som går ut over sosialt miljø, stolthet og kompetanse i bygda

iii Manglende markedsmuligheter og lite nysatsing. Liten innsats fra forvaltning, befolkningen og markedsaktører

iv Skjøtselsutfordringer: $\AA$ sikre nok beitedyr og interesserte folk.

\section{Jordbrukslandskap med nærhet til by- og} tettsted og attraktive friluftsområder
Utfordringer:

i Press pga by- og tettstedvekst eller fritidsutbygging

ii "Marked" for nye varer, tjenester og "landskapsgoder" utnyttes ikke

iii Mulighet for sysselsetting og inntekter utenom gården konkurrerer om ressurser til skjøtsel og nye næringer

iv Skjøtselsutfordringer: $\AA$ sikre nok beitedyr og interesserte folk

3. Kulturlandskap i aktive, stabile jordbruksbygder, stor landbruksproduksjon.

Utfordringer:

i Tap av natur- og kulturhistoriske verdier pga rasjonalisering og intensivering av drift, reduksjon i antall bruk.

ii Redusert bruk og forfall av naturbeiter/gammel kulturmark og gamle bygninger.

iii Manglende status, interesse og kompetanse for å produsere miljøgoder og sette i gang med nye næringer.

iv Bygdemiljø og sosialt nettverk er under press. Endringer i jordbrukets rammevilkår kan raskt endre denne kategorien.

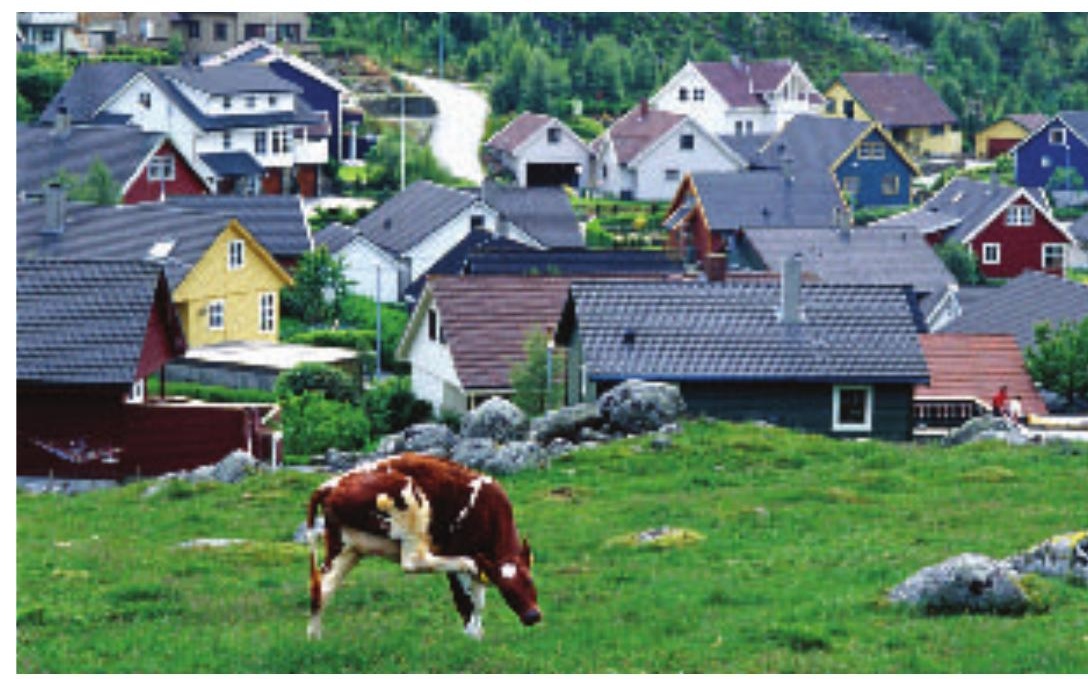

Mange by-og tettstedsnære jordbrukslandskap får press fra nye boligområder. Utfordringen er å bevare og utvikle jordbrukslandskapet til å bli en positiv ressurs både for den nye tilflyttede befolkningen og for bonden. Foto: Oskar Puschmann, NIJOs. 


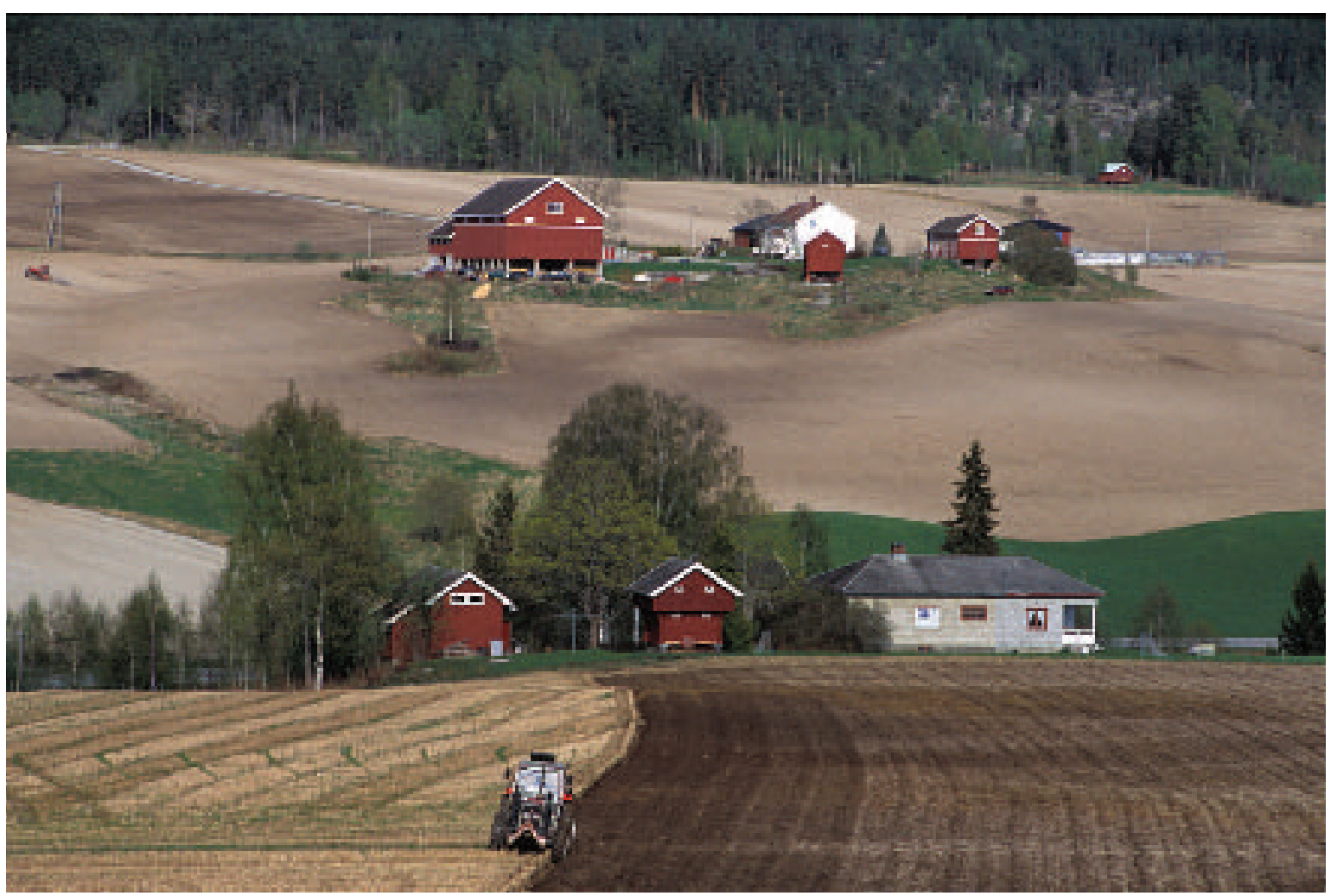

Mer intensivt drevne, og gjerne sentralt beliggende jordbruksområder oppfattes som relativt stabile jordbruksområder. Også her kan det skje endringer. Foto: Oskar Puschmann, NIJOs.

I alle tre kategorier landskap kan vi finne arealer som er særlig verdifulle med tanke på natur- og kulturhistoriske verdier og landskapet som helhet. Utfordringene og mulighetene for å få til skjøtsel og bevaring er likevel ulike. Det kan også være en blanding av disse utfordringene innen samme område/bygd, for eksempel der innmark fortsatt intensiveres, mens utmark gror igjen. Utbygging i landskapet kan skje både nær tettsteder og i områder der hovedtendensen er nedlegging i landbruket, for eksempel som følge av utbygging av hytteområder. Å sikre langsiktig lønnsomhet i jordbruksproduksjon, husdyrbruk og tilhørende næringer er en utfordring $\mathrm{i}$ alle tre typer områder.

I det første tilfellet der nedlegging og fraflytting er dominerende, er også knapphet på mennesker og kunnskap viktig. Det er nok arealer, men fare for tap av natur- og kulturhistoriske verdier. Mulighetene ligger $i$ at forvaltningen, markedsaktører, lokalsamfunn, bønder eller organisasjoner verdsetter landskapet, ser framtidige mulighetene og er villige til å satse.

Også i det andre tilfellet konkurrerer landbruket med andre sektorer om både arealer og mennesker, men har samtidig tilgang til større markeder og alternative inntekstmuligheter. Utbygging kan true jordbrukslandskapet og de natur- og kulturhistoriske verdiene.

I det tredje tilfellet er det stort sett nok menneskelig ressurser, men sosialt og faglig miljø blir sårbart pga reduksjon i antall bruk. I disse landskapene må dessuten ivaretakelse av de spesielle verdiene konkurrere med matproduksjon om ressurser og oppmerksomhet. Her kan effektivisering allerede ha pågått $\mathrm{i}$ stort omfang gjennom flere tiår, slik at mange kvaliteter allerede kan ha gått tapt.

Jordbrukslandskapet kan være en ressurs som gir mange fremtidige muligheter for samfun- 
net. Dagens utvikling i jordbrukslandskapet byr imidlertid på en rekke utfordringer dersom vi skal kunne nyttegjøre oss disse mulighetene. Det er også viktig å være oppmerksom på at utviklingen mange steder går svært fort, og det er derfor nødvendig å handle raskt. I svært mange tilfeller vil det være meget ressurskrevende, om i det hele tatt mulig, å gjenskape et kulturlandskaps verdier når de først er gått tapt.
Når et tidligere lysåpent beiteareal ikke lenger beites, varer det ikke mange år før gjengroing gradvis blir et faktum. Bildene her viser samme sted fotografert i 1992 og 2002. Disse bildene har hat en tankevekkende effekt på stedets gårdbrukerne ved at de utløste konkrete tiltak for å gjenåpne området $i 2004$. Valle, Setesdal, Norge. Foto: Oskar Puschmann, NIJOs.

\section{Menneskelige ressurser, inntektsmuligheter}

(i form av tilskudd eller inntekter av salg av ulike gardsprodukter og tjenester) og antall beitedyr er de viktigste minimumsfaktorer for å kunne ivareta landskapsverdiene i et langsiktig perspektiv. Årsakene til dette og muligheter for utvikling er likevel ulike for de tre kategoriene ovenfor.
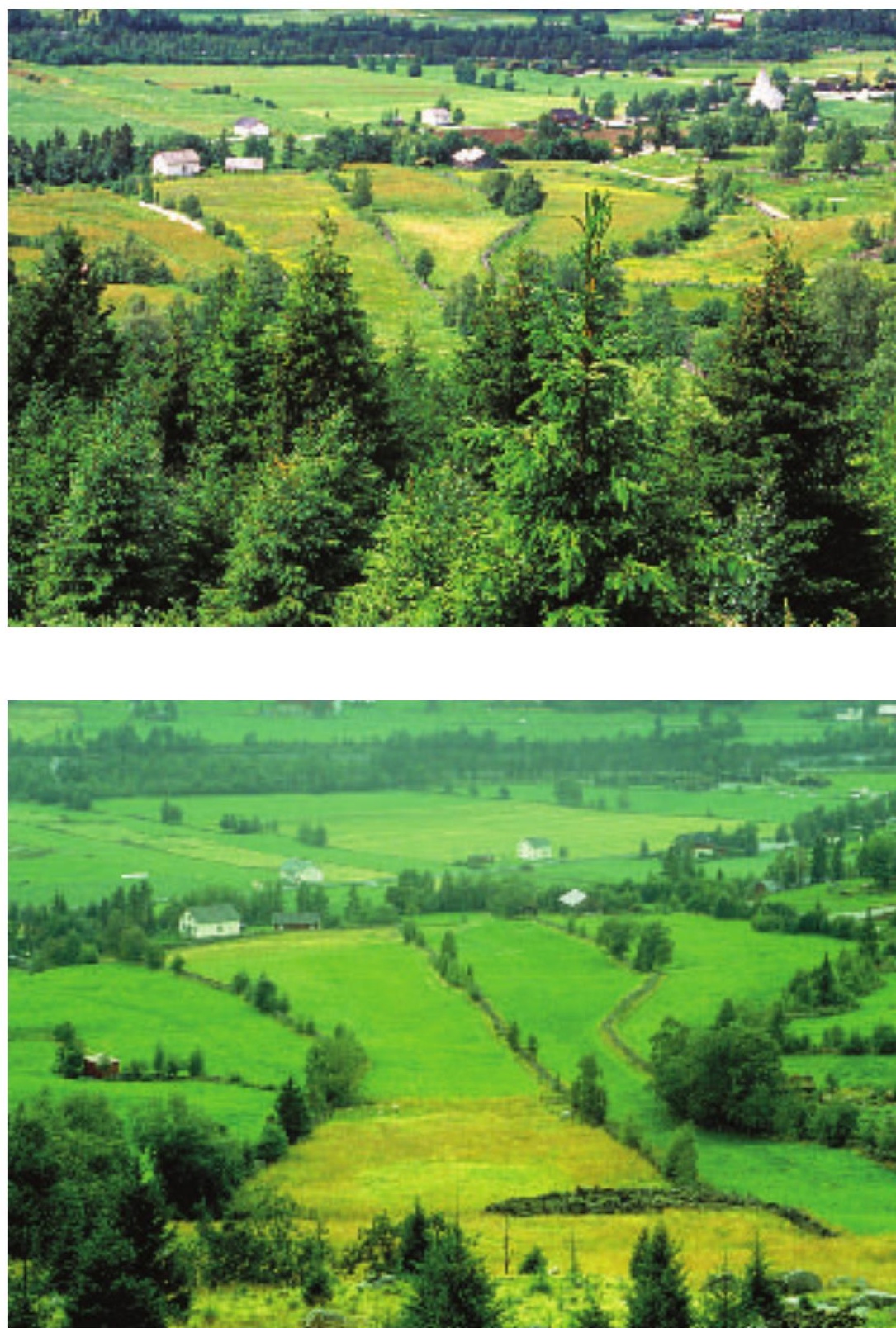


\section{Mål og strategier for jordbrukslandskap i de nordiskelandene, Nordisk ministerråd og EU}

\subsection{Danmark}

Landbrugslovens formål er blandt andet, at værne dyrkningsjordene og de tilknyttede landskabelige værdier, således at både jordbruget, erhvervsøkonomiske interesser og hensynet til det omgivende miljø tilgodeses, men der findes endnu ikke konkrete langeller kortsigtede mål for en miljøvenlig landbrugsdrift i landbrugspolitik, støtteordninger eller handlingsplaner for landbruget eller lignende.
Landbruget er undtaget størstedelen af planlovens reguleringer af det åbne land, idet udgangspunktet er, at landzonen skal friholdes for anden bebyggelse m.v. end den, der er nødvendig for driften af landbrug, skovbrug og fiskeri. I de senere år er der imidlertid sket en lempelse af reglerne for anvendelse af bygningsmassen i det åbne land, idet der kan indrettes og udbygges andet erhverv og flere boliger end det for landbruget nødvendige på den enkelte ejendom.

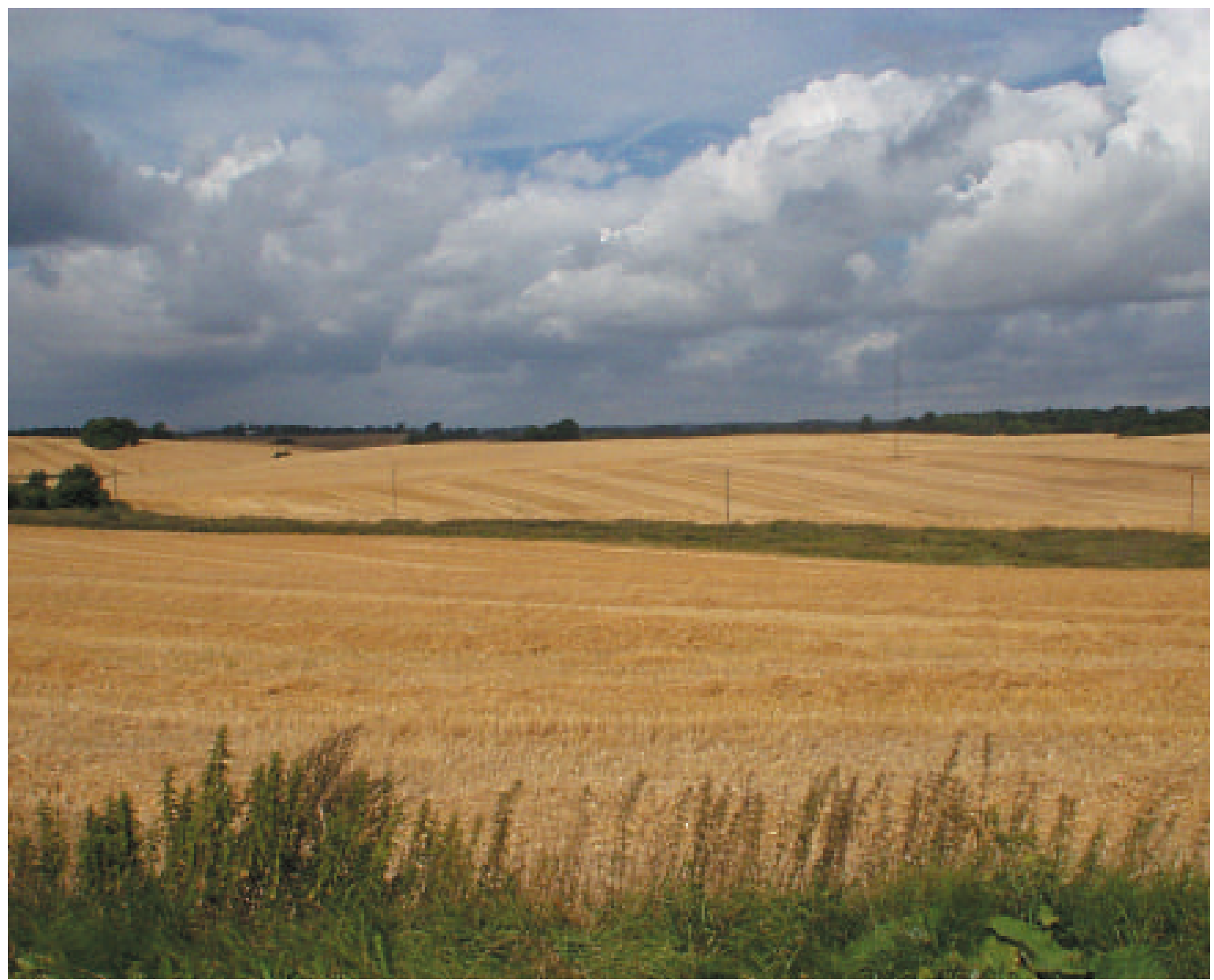

Bølgende åkre med kantsoner i Danmark.

Foto: Anette Ginsbak 
Opgaver vedrørende formidling og tilgængelighed i relation til synlige fortidsminder, kulturmiljøer og kulturlandskab indgår som del af naturforvaltningsprojekterne generelt og på statens egne arealer varetages landskabelige og kulturhistoriske hensyn. Virkemidler på det kulturhistoriske område er knyttet til andre lovområder end landbrugsloven.

Ifølge planloven skal amternes regionplaner indeholde retningslinjer for varetagelsen af bevaringsværdier og naturbeskyttelsesinteresser i det åbne land. Regionplanlægningen skal indeholde retningslinjer, der sikrer værdifulde kulturmiljøer i det åbne land, herunder at f.eks. byudvikling, anlægsarbejder, skovtilplantning og naturgenopretning samt forvaltning af landskabet i øvrigt sker i respekt for de kulturhistoriske interesser knyttet til værdifulde kulturmiljøer. Som grundlag for de regionale retningslinjer skal der udpeges værdifulde kulturmiljøer. Som en del af regionplanlægningen skal der udføres vurderinger af virkningerne på miljøet - VVM ( EIA,

Environmental Impact Assessment) af konkrete anlægsarbejder, der må antages at påvirke miljøet væsentligt. Landskab og kulturmiljø indgår som elementer i VVM-reglerne.

Skovbruget er en del af jordbruget er reguleret af skovloven. Ved lovens administration skal der lægges vægt på at sikre, at skovene dyrkes med henblik på bl.a. at varetage landskabelige og kulturhistoriske hensyn og i de offentlige skov skal disse hensyn tillægges særlig vægt.

\subsection{Finland}

I målsättningen för miljövården har Finland förbundit sig att efterfölja internationella avtal. Idkad miljöpolitik efterföljer EU:S allmänna målsättningar, naturligtvis utgående från nationella särdrag och behov. Detta gäller också landsbygds- och lantbrukspolitiken. Vården av miljö och landskap samt utnytt- jande av kulturvärden som del av landsbygdsutveckling ses som en central möjlighet och medel att höja landsbygdens livskraft.

I förbindelse med registreringen av värdefulla kulturlandskap vidtog regeringen år 1995 mål för tillvaratagande och skötsel av områden. Markanvändnings- och byggnadslagen utgör grundläggande stadgar för planläggning och byggande med tillhörande vård av kulturmiljön. Finlands nationella handlingsprogram för den biologiska mångfalden 1997-2005 berör också lantbruksmiljöerna. Det gamla byggnadsbeståndet bildar en väsentlig del av kulturlandskapet. I jord- och skogsbruksministeriets Strategi för byggande utgör en huvudmålsättning god skötsel av byggnadsarvet och ett kunnigt restaurerande av byggnader samt utnyttjande av byggnadsarvet inom landsbygdens näringar. För vårdandet $\mathrm{av}$ byggnadsarvet har man i Finland uppgjort en strategi för byggnadsarvet.

\section{I jord- och skogsbruksministeriets strategi} för naturresurser samlas de mål för en hållbar användning av förnybara naturresurser som finns inom ministeriets verksamhetsfält. I strategin ses främjandet av landsbygdslandskapet och dess utnyttjande för landsbygdsnäringar som en central uppgift för ministeriet.

I Finland har man skapat samarbetsgrupper mellan olika myndigheter och organisationer för att ta hand om kulturlandskapet på regionala nivån. En av målsättningarna med miljöstödet är bevarande av naturens mångfald, landsbygdslandskapets vård och främjande av möjligheter till rekreation som komplement till det traditionella jordbruket. Det horisontala utvecklingsprogrammet för landsbygden innehåller bl.a. systemet för miljöstöd för lantbruket åren 2000 - 2006. Miljöstödet är en del av EU:s stödsystem för jordbruket där stödet bildar en del av lantbrukarens inkomster. 


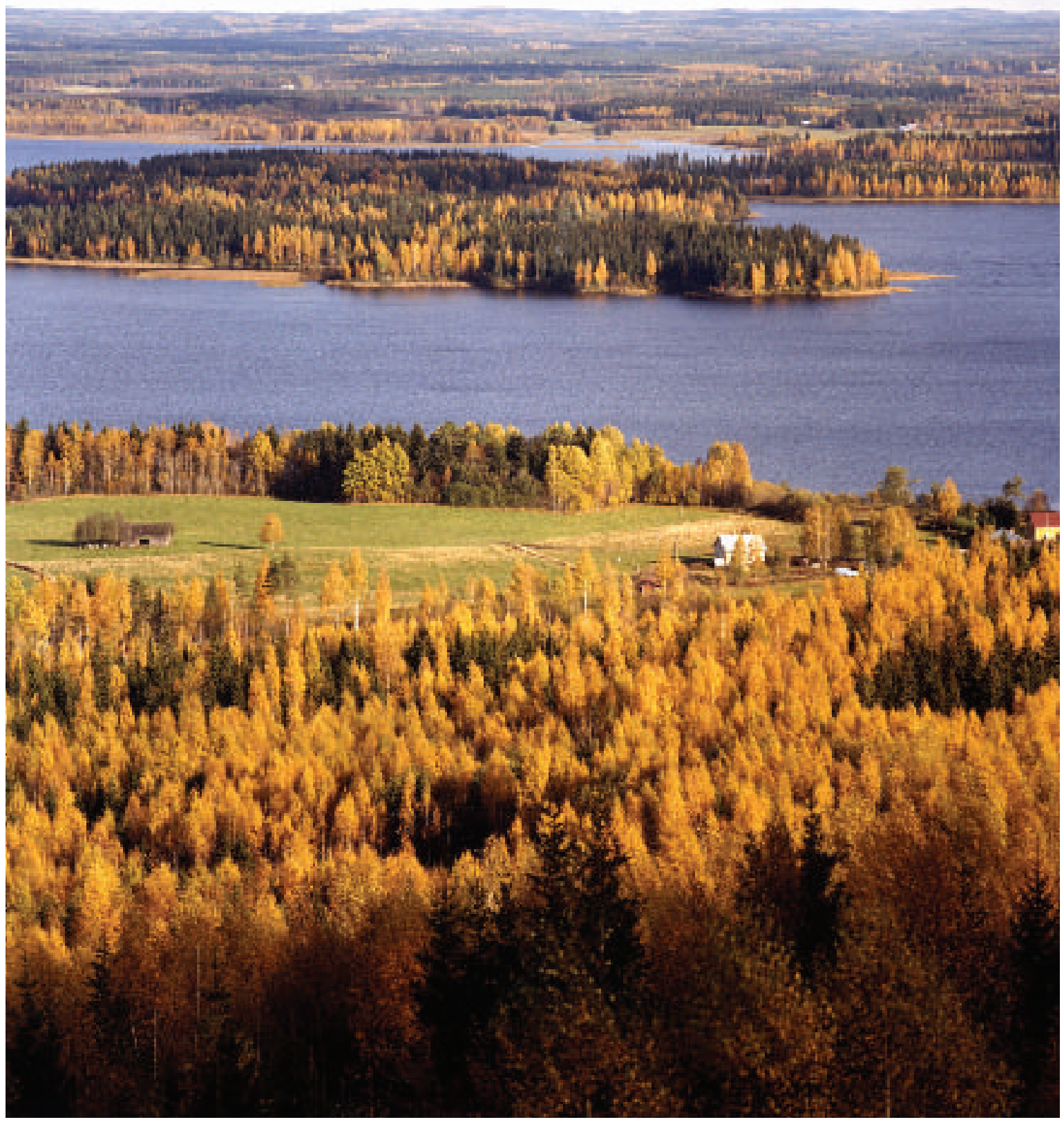

Skog, vann, jordbruksmark og hus. Fra Lapinlahti, Østra Finlands län. Foto: Tapio Heikkilä. 


\subsection{Island}

I Island har landskap de siste femti år veid tungt eller vært avgjørende for utpeking av nasjonalparker og fredete områder. Likevel har Island ennå ikke utviklet noen enhetlig landskapspolitikk. Nasjonale mål for landskap har ikke vært definert, og ennå er det ikke gjennomført noen systematisk planlegging for vurdering eller beskyttelse av islandske landskap. Det beredes nå en nasjonal naturvernplan som forhåpentligvis vil bli et viktig steg mot en slik plan. Landskapsverdier har stort sett ikke spilt noen stor rolle i byplanlegging eller planlegging av bebodde områder, og vern av kulturlandskap har hittil ikke vært spesifisert som fredningsmål. Det tas dog hensyn til beskyttelse av kulturminner eller kulturlandskap både i Naturvernlovens formålsparagraf og paragrafene om naturvernplan for hele landet. Landskapshensyn har til gjengjeld vært svært framtredende i debatten om vannkraftverk i det sentrale høylandet.

I Islands naturvernlov finnes det ikke alminnelige bestemmelser om vern eller forvaltning av landskap som helhet; det fokuseres mer på habitattyper (iflg. Paragr. 37).

Naturvernloven krever blant annet at større planer som kommune- eller regionplaner skal forelegges Miljöstyrelsen og at alle større inngrep som kan forandre landskapets karakter skal ta hensyn til landskapet. Ved skogplanting eller annen oppdyrking skal det taes hensyn til landskapets karakter, slik at naturog kulturminner ikke ødelegges. En rekke geologiske forekomster er særlig beskyttet $\mathrm{i}$ loven, men mer som enkeltobjekter. I miljøkonsekvensloven er landskap definert som en miljøkomponent og særlig hensyn skal tas til høylandet, isbreer, villmark og landskap. Vern av kulturlandskap er spesifisert i kulturminneloven(fornminneloven). I de siste år har landskap fått større vekt i miljøkonsekvensanaly-

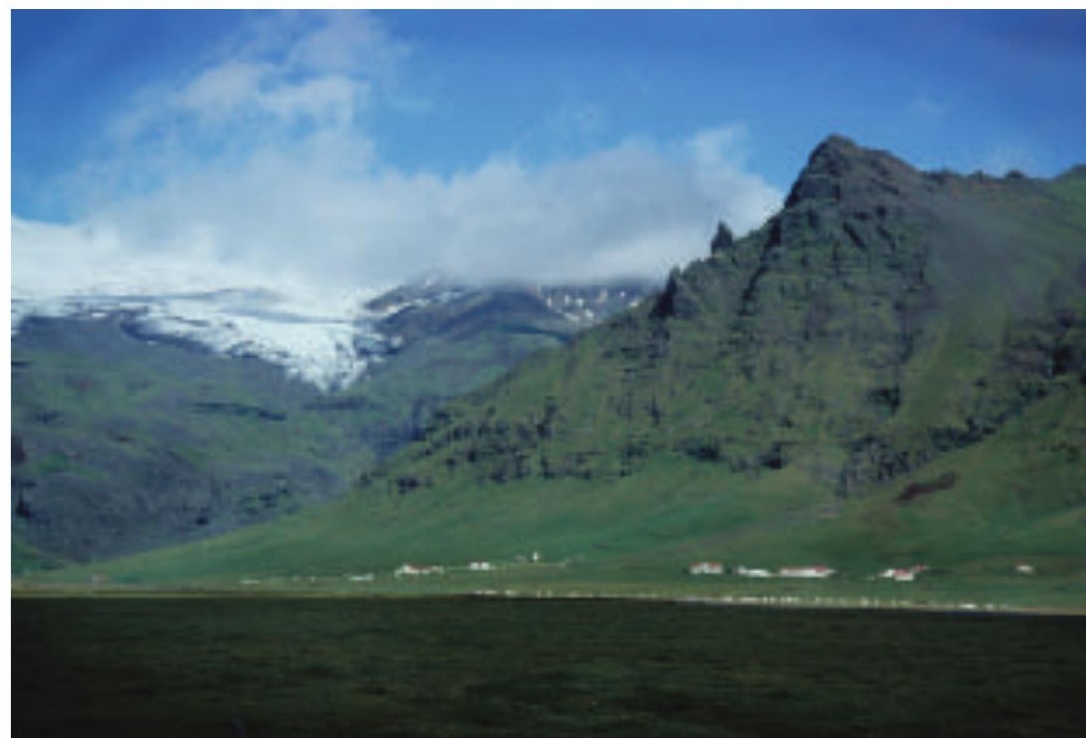

Gårdsbruk med jordbruksareal mellom sjø, fjell og bre på Island. Foto: Anna Fjóla Gísladóttir

ser og i "Rammaaætlun" ( Samlet plan for vassdrag) er det arbeidet med klassifisering av landskap - spesielt i höyfjellet. Det har også vist seg at vern og forvaltning av landskap er vanskelig på grunn av mangel på metodikk, mål og nasjonale referanser for landskapsvurderinger.

\subsection{Norge}

Målene for arbeidet med landbrukets kulturlandskap i Norge fremgår av stortingsdokumenter; blant annet de årlige budsjettproposisjoner ${ }^{6}$. Hovedmålet for mat- og landbrukspolitikken er å sikre trygge matvarer og fremme mangfold og forbrukerhensyn med grunnlag i et bærekraftig, utviklingsorientert og markedsbasert landbruk, som utnytter potensialet for økt verdiskaping og som medverker til levende bygder med høy produksjon av fellesgoder. Nasjonale miljømål for kulturlandskap, kulturminner og biologisk mangfold er fastsatt i Regjeringens miljøpolitikk og rikets miljøtilstand ${ }^{7}$.

6 senest St prp 1 (2003-2004) Landbruksdepartementet

7 St meld $\mathrm{nr} 25$ (2002-2003) Regjeringens miljøpolitikk og rikets miljøtilstand 


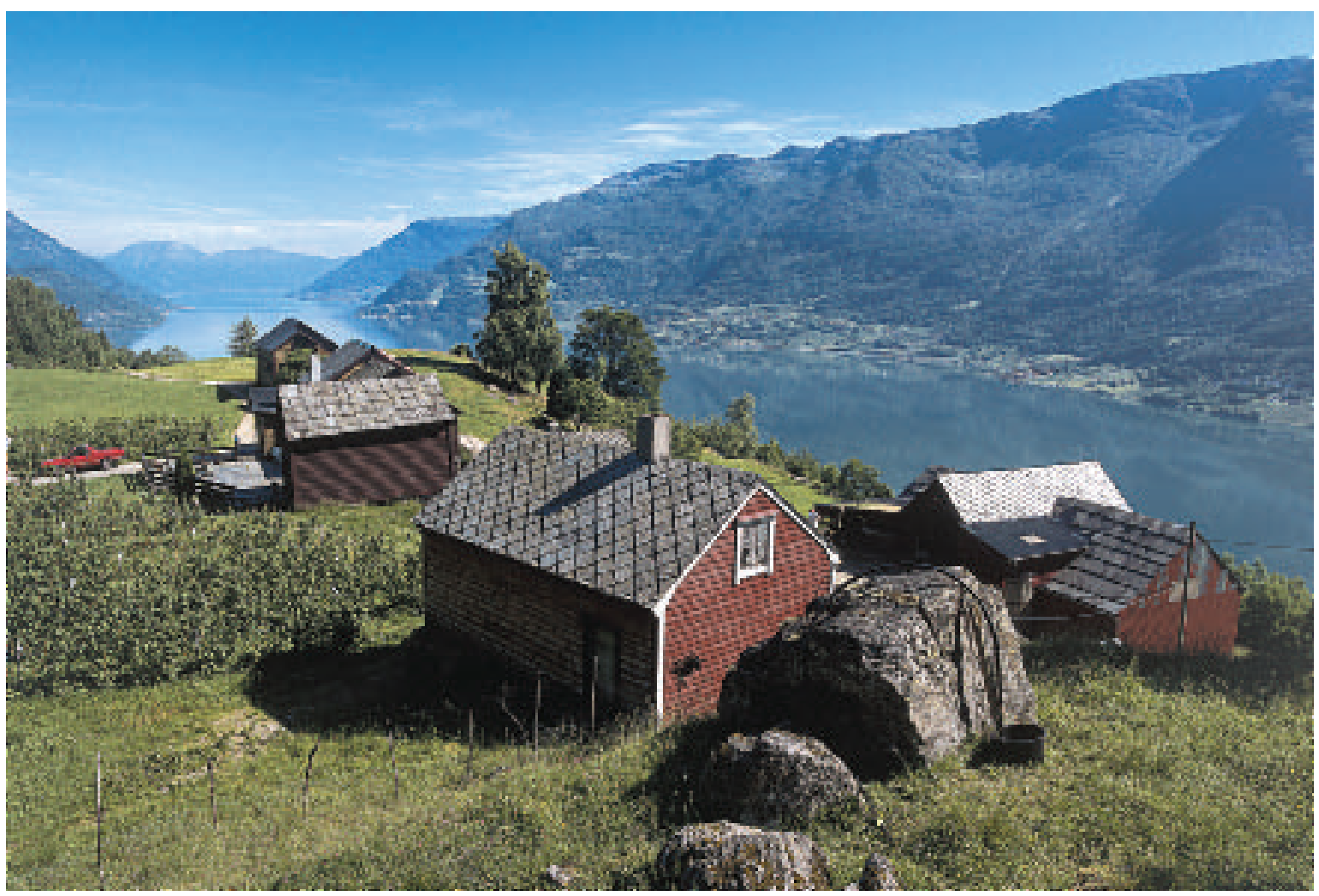

Hyllegård i Hardanger. Ullensvang kommune, Hordaland. Foto: Oskar Puschmann, NIJOs.

I Landbruksdepartementets miljøhandlingsplan (2001-2004) er målet å legge til rette for bærekraftig jordbruksdrift som ivaretar ressursgrunnlaget og de livsbærende økologiske prosessene. Dette omfatter også å ta vare på viktige kulturlandskap, kulturmiljøer, biotoper, økosystemer og naturlig og domestisert biologisk mangfold knyttet til de dyrkende arealene (med restarealer og kantsoner rundt) og til de landbrukspåvirkede utmarksarealene.

Nasjonalt miljøprogram for landbruket iverksettes i år og inneholder nasjonale mål for landbrukspolitikk og rutiner for rapportering. Dette er en overbygning for regionale miljøprogram for landbruket som skal etableres i alle fylker fra $2005^{8}$. Regionale miljøprogram skal inneholde en analyse og en prioritering av miljøutfordringer knyttet til landbruket $i$ fylket samt tilskuddsordninger rettet mot å løse disse utfordringene. Ansvaret for utfor- ming av miljøprogrammene er lagt til fylkesmennene, men kommunene og næringsorganisasjonene trekkes aktivt inn i arbeidet. Alle landbruksforetak som mottar generelle arealtilskudd skal ha egen miljøplan.

Fra 2004 har kommunene fått vedtaksmyndighet for de spesielle miljøtilskuddene innen både jordbruk og skogbruk. Målet er å øke det lokalt engasjement og handlingsrom for landbruk, landbrukspolitikk, verdiskaping og landsbygder.

\subsection{Sverige}

Sveriges riksdag antog 15 miljökvalitetsmål år 1999. Målen beskriver den kvalitet och det tillstånd som är ekologiskt hållbart på lång sikt för landets miljö samt för natur- och kulturresurser. Miljökvalitetsmålen syftar bl.a. till att värna om den biologiska mångfalden och 
naturmiljön samt ta till vara kulturmiljön och de kulturhistoriska värdena. De flesta av miljökvalitetsmålen ska vara uppnådda eller åtminstone flertalet av åtgärderna ska vara genomförda inom en generation.

Ett rikt odlingslandskap heter det miljökvalitetsmål som främst behandlar jordbrukets kulturlandskap. Enligt Ett rikt odlingslandskap ska odlingslandskapets och jordbruksmarkens värde för biologisk produktion och livsmedelsproduktion skyddas samtidigt som den biologiska mångfalden och kulturmiljövärdena bevaras och stärks. Exempel på delmål är att befintliga ängs- och betesmarker ska bevaras och skötas på ett sätt som bevarar deras värden och dessutom att de ska öka med vissa areal till 2010. Mängden kulturbärande landskapselement som vårdas ska öka med 70\% till 2010. Senast år 2005 ska ett program finnas för hur lantbrukets kulturhistoriskt värdefulla ekonomibyggnader kan tas till vara.

De övergripande målen för verksamheten inom det jordbruks- och livsmedelspolitiska området i Sverige är att verka för en konkurrenskraftig, miljö- och djurskyddsanpassad livsmedelsproduktion till nytta för konsumenterna samt att skapa förutsättningar för ett livskraftigt jordbruk i mindre gynnade områden. När det gäller miljö- och landsbygdsåtgärder är målet att tillvarata och utveckla jordbrukets positiva och minimera dess negativa miljöeffekter samt verka för en livskraftig landsbygd. Lantbrukarens roll som företagare ska också främjas och underlättas.

Riksantikvarieämbetet (RAÄ) är den myndighet som har ett övergripande ansvar för kulturmiljön och för de delar i miljökvalitetsmålen som rör dessa frågor. RAÄ ska verka för att odlingslandskap kan bevaras och brukas, att mängden kulturbärande landskapselement som vårdas ökar, ett fortsatt och utökat skydd av fjällens forn- och kulturlämningar samt av kulturmiljövärden i skogslandskapet och i våtmarker.
Sverige har ett samlat miljö- och landsbygdsprogram för perioden 2000-2006 (LBU-programmet) där mål och styrmedel för landets miljöarbete på jordbruksområdet preciseras. Programmet ska främja en ekologiskt, ekonomiskt och socialt hållbar utveckling av jordbruket, livsmedelsproduktionen, skogsbruket och landsbygden. Tyngdpunkten för åtgärderna i programmet ligger på ekonomiskt stöd för ekologiskt hållbara brukningsmetoder, för kollektiva nyttigheter som jordbruket producerar samt för främjande av utvecklingen av alternativa möjligheter för hela landsbygdens ekonomiska och sociala utveckling.

\subsection{Nordisk ministerråd}

Nordisk bærekraftstrategi er en langsiktig strategi fram til 2020. Handlingsdelen inneholder strategier for perioden 2000-2004. Følgende mål og strategier er særlig relevante for landbrukets kulturlandskap, og er hentet fra tverrgående kapitler som gjelder flere sektorer:

\section{Kap 3.10 Kulturmiljøet som en dimension i den integrerede miljøindsats}

At sikre kulturmiljøet indebærer, at man bevarer den mangfoldighed af udtryksformer og de spor i landskabet og i det bebyggede

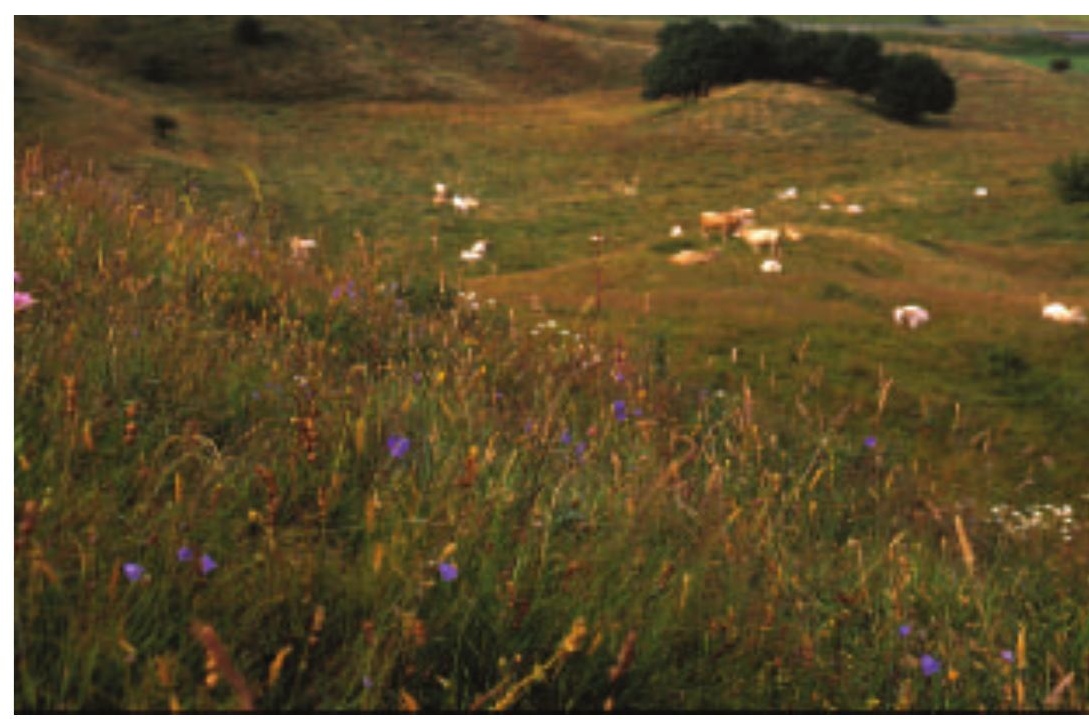

Naturbeite med storfe i Sverige Foto: Urban Wigert 
miljø, som afspejler de nordiske landes historie i hele sin tidsmæssige, funktionelle og egenkarakteristiske mangfoldighed. De nordiske lande vil arbejde for, at kulturmiljøet bliver en integreret del af miljøindsatsen. I arbejdet skal bl.a. belyses kystkulturens særart og livskraft og samspillet mellem natur- og kulturmiljøværdier i jord- og skovbruget....

....Det er målet, at arbejdet sker i tæt samarbejde med nærområderne, og at den fælles indsats vil styrke Nordens profil på kulturmiljøområdet $\mathrm{i}$ internationale fora.

\section{Kap 3.11 Strategi for sikring af de nordiske landskaber}

For at udmønte den europæiske landskabskonvention sigtes der mod at udarbejde en fælles nordisk strategi, der skal sikre de nordiske landskabers diversitet og særegenhed og rekreative anvendelse, som er tilpasset lokale forhold. Arbejdet skal tilrettelægges i gensidig erfaringsudveksling med andre europæiske lande og nærområderne, og skal medvirke til at styrke den nordiske indflydelse i det internationale samarbejde...

\section{Kap 3.13 Biologisk mangfoldighed i land- og skovbrug}

Styrke beskyttelsen af den biologiske mangfoldighed i kulturlandskabet (in-situ) (s 33) Det er et mål at styrke det nordiske samarbejde om kulturlandskabet $\mathrm{i}$ land- og skovbrug for at fremme in-situ bevaringen af den biologiske mangfoldighed. En vigtig strategi for at bevare den biologiske mangfoldighed $i$ land- og skovbruget er at tage vare på det tilbageværende gamle kulturlandskab og eventuelt genskabe områder drevet efter gamle land- og skovbrugsmetoder. Dette arbejde bør indgå i den tværsektorielle nordiske strategi for bevaring af det nordiske landskab..."

\subsection{EU}

Nedenfor har prosjektets svenske representant gitt en omtale mål og strategier i EU kommisjonens programmer og virkemidler innen miljø, landbruk og landsbygd som særlig er relevante for de nordiske EU-medlemmer.

\section{EU: $\mathbf{s}$ sjätte miljöhandlingsprogram}

Som ram för miljöpolitiken i EU fastställdes 2002 gemenskapens sjätte miljöhandlingsprogram. Genom programmet fastställs miljöprioriteringar för gemenskapens åtgärder med inriktning särskilt på:

- klimatförändringar

- natur och biologisk mångfald

- miljö, hälsa och livskvalitet

- naturresurser och avfall.

De mål som ingår i programmet ska uppfyllas inom en tioårsperiod. När det gäller punkt 2 ovan så syftar programmet till att skydda, bevara, återställa och utveckla de naturliga systemens, de naturliga livsmiljöernas samt vilda växter och djurs sätt att fungera. Syftet är att hejda ökenspridningen och förlusten av biologisk mångfald, inklusive mångfalden av genetiska resurser, både i EU och globalt sett. Ett mer preciserat mål avseende natur och biologisk mångfald är att bevara och på lämpligt sätt återställa särskilt natursköna områden, inklusive odlade och känsliga områden. Dessutom ska arter och livsmiljöer bevaras och fragmentering av livsmiljöer särskilt förebyggas.

Målen för natur och biologisk mångfald ska bl.a. uppnås genom övervakning och utvärdering, forskning, åtgärder för skydd av Natura 2000-nätverket samt av arter som skyddas enligt habitat- och fågeldirektiven. Man har för avsikt att främja integreringen av hänsynen till biologisk mångfald $\mathrm{i}$ jordbrukspolitiken och uppmuntra till en hållbar utveckling av landsbygden.

\section{EU:s jordbrukspolitik}

I juni 2003 kom EU:s jordbruksministrar överens om en reform av den gemensamma jordbrukspolitiken (CAP). Överenskommelsen innebär två principiellt viktiga förändringar av den gemensamma jordbrukspolitiken. Den 
ena förändringen består $\mathrm{i}$ att de nuvarande direktstöden till jordbrukaren omvandlas till ett inkomststöd, så kallat gårdsstöd. Stödet utgår till jordbrukaren oberoende av produktionens inriktning eller omfattning. Villkoret för att stödet skall betalas ut är att de s.k. tvärvillkoren uppfylls. Tvärvillkoren består av krav på uppfyllande av lagstiftning inom folkhälsa, djurhälsa, växtskydd, miljö- och djurskydd.

Den andra principiellt viktiga förändringen är att medlemsstaterna ges större inflytande över hur jordbrukspolitiken skall utformas i det egna landet. Det ökade inflytandet innebär att medlemsstaterna kan välja om hela stödet skall utgå till jordbrukaren frikopplat från produktionen eller om, för en eller flera sektorer, en del av stödet skall villkoras med att en produktion upprätthålls.

Medlemsstaterna kan även välja att regionalisera stöden, dvs. fördela ut stöden lika på all mark $i$ en region samt att avsätta upp till 10 procent av de nya frikopplade gårdsstöden för att stödja särskilda typer av jordbruk som är viktiga för att skydda och förbättra miljön eller för att förbättra kvaliteten och saluföringen av jordbruksprodukter genom ett så kallat nationella kuvertet.

Direktstöden kommer, genom s.k. modulering, fr.o.m. år 2005 kommer att dras ned successivt med 3 procent för att år 2007 dras ned med 5 procent. De medel som därigenom frigörs kan användas till att förstärka medlemsländernas miljö- och landsbygdsprogram.

Kommissionens utgångspunkt för förslaget till reform av jordbrukspolitiken var den strategi om hållbar utveckling som Europeiska rådet enades om i Göteborg våren 2001. Övergripande mål med reformen var att stärka konkurrenskraften i europeiskt jordbruk. Stöd frikopplade från produktionen i kombination med minskat behov av interventionsåtgärder innebär ett mer konsument- och marknadsorienterat jordbruk. Dessutom innebär stöd till producenten i stället för till produktionen mer effektiva inkomststöd. En viktig faktor var även att EU:s förhandlingsposition $\mathrm{i}$ jordbruksförhandlingarna inom WTO förstärks när stöden frikopplas från produktionen eftersom de då kategoriseras som icke handelsstörande stöd. Modulering, dvs. överföring av pengar från den traditionella jordbrukspolitiken till miljö- och landsbygdsutveckling föreslogs för att uppnå målsättningen om ett hållbart jordbruk på ett bättre sätt. Det samma gäller införandet av tvärvillkoren.

Sedan tidigare har varje land utformat ett program för landsbygdens utveckling (enligt rådets förordning (EG) nr 1257/1999). Dessa program påverkas egentligen inte av reformen som beskrivs ovan men kan komma att förstärkas ekonomiskt. I dessa program ingår ytterligare miljöåtgärder $\mathrm{i}$ jordbruket och landsbygdsutveckling. Inom CAP betraktas landsbygdens utveckling som den "andra pelaren" i den gemensamma jordbrukspolitiken, likställd med marknadspolitiken. Detta förutsätter att jordbrukarna, för en viss ersättning, gör både medvetna och frivilliga åtaganden för att främja ett "grönare" jordbruk. Således betraktas miljön som en viktig dimension av jordbrukets och landsbygdens utveckling och av jordbrukarnas yrkesverksamhet.

Inom EU arbetar man utifrån att ett mer miljövänligt jordbruk inte betyder en återgång till föråldrade metoder. En väg till ett hållbart jordbruk är t.ex. ekologiskt jordbruk, som inte använder kemiska bekämpningsmedel eller mineralgödselmedel. 


\section{Hvordan nå miljø- og samfunnsmålene for jord- brukslandskap i Norden - erfaringer og forslag}

\subsection{Overgripende politikk og prinsipper}

Prosjektet mener at jordbrukslandskapets utvikling i mye sterkere grad må diskuteres politisk:

- Endringene i internasjonale og nasjonale rammevilkår med internasjonal liberalisering og rasjonalisering, gjør det nødvendig å utvikle nye virkemidler og sikre rammevilkår.

- Det må fokuseres på samspillet mellom kulturlandskap og de utvidete oppgaver landbruket må ha i framtida. Kulturlandskapet må gi mulighet for rekreasjon og opplevelser for befolkningen, skape arbeidsplasser og inntekter og være en kunnskapsbase om mennesker, natur og kultur.

- Det bør utformes en framtidsrettet nordisk strategi for jordbrukslandskapet.

Det er en gjensidig avhengighet mellom utviklingen i jordbrukslandskapet, levende lokalsamfunn og muligheter for verdiskaping. Vedlikehold av jordbrukslandskap er også et viktig ledd i å nå miljømål for biologisk mangfold, kulturminner og kulturhistorie og for friluftsliv og estetikk.
Følgende kriterier er avgjørende for å fremme jordbrukslandskapene i Norden:

- Et livskraftig jordbruk

- En landsbygdspolitikk og landsbygdsprogram som fungerer og gir mulighet for verdiskaping

- Klart definerte og konkrete miljømål for jordbruksproduksjon og -landskap, der mål for biologisk mangfold og kulturmiljøer i jordbrukslandskapet inngår

- Et fungerende sektoransvar og ansvarsdeling med andre aktører

- Diskusjon og utvikling av forholdet mellom vern og bruk

- Forankring i lokalsamfunnene og hos den enkelte bonde gjennom deltakelse i debatt og beslutningsprosesser.

I Nordens demokratiske samfunn bør en styrke befolkningens muligheter til være med å påvirke hvordan jordbrukslandskapet skal utvikle seg. Det krever kunnskap og engasjement i samfunnet, men også systemer som ivaretar og skaper motivasjon for å delta $i$ beslutninger.

I Danmark er det gjennomført undersøkelser av hvordan befolkningen bruker landskapet som arena for rekreasjon og friluftsliv. Så mange som $96 \%$ av den danske befolkning er på tur $i$ landskapet minst en gang $i$ året, og 75\% oppgir å ha vært der i løpet av de siste 14 dagene. Dette betyr at landskapet tiltrekker en betydelig større del av befolkningen enn for eksempel bibliotek, kunstutstillinger og idrettsplasser.

I gjennomsnitt tilbakelegger danskene $18 \mathrm{~km}$ for å komme til det sted hvor turen skal begynne. Ved å se litt nærmere på tallene kommer det frem at $25 \%$ av turene foregår innefor en avstand på 2 kilometer fra der folk bor, mens $66 \%$ forflytter seg $10 \mathrm{~km}$ vekk. Knapt $20 \%$ forflytter seg mer enn 20 kilometer hjemmefra. De fleste turer varer 1-2 timer, og når det gjelder type aktivitet var det to som skilte seg ut som de klart vanligste i undersøkelsen; "å gå tur" og "å oppleve naturen/stedet". 
I Danmark er skogene de mest populære turområdene. Hele 67\% har vært i skogen på sin seneste tur, noe som er interessant sett i lys av at bare $11 \%$ av Danmarks areal er skog. Til sammenligning var det $48 \%$ som hadde vært på stranden, og 34\% ved markene. Det understrekes imidlertid $i$ undersøkelsen at mange besøker flere steder og landskapstyper på samme tur. Tvedt \& Jensen, 1999.

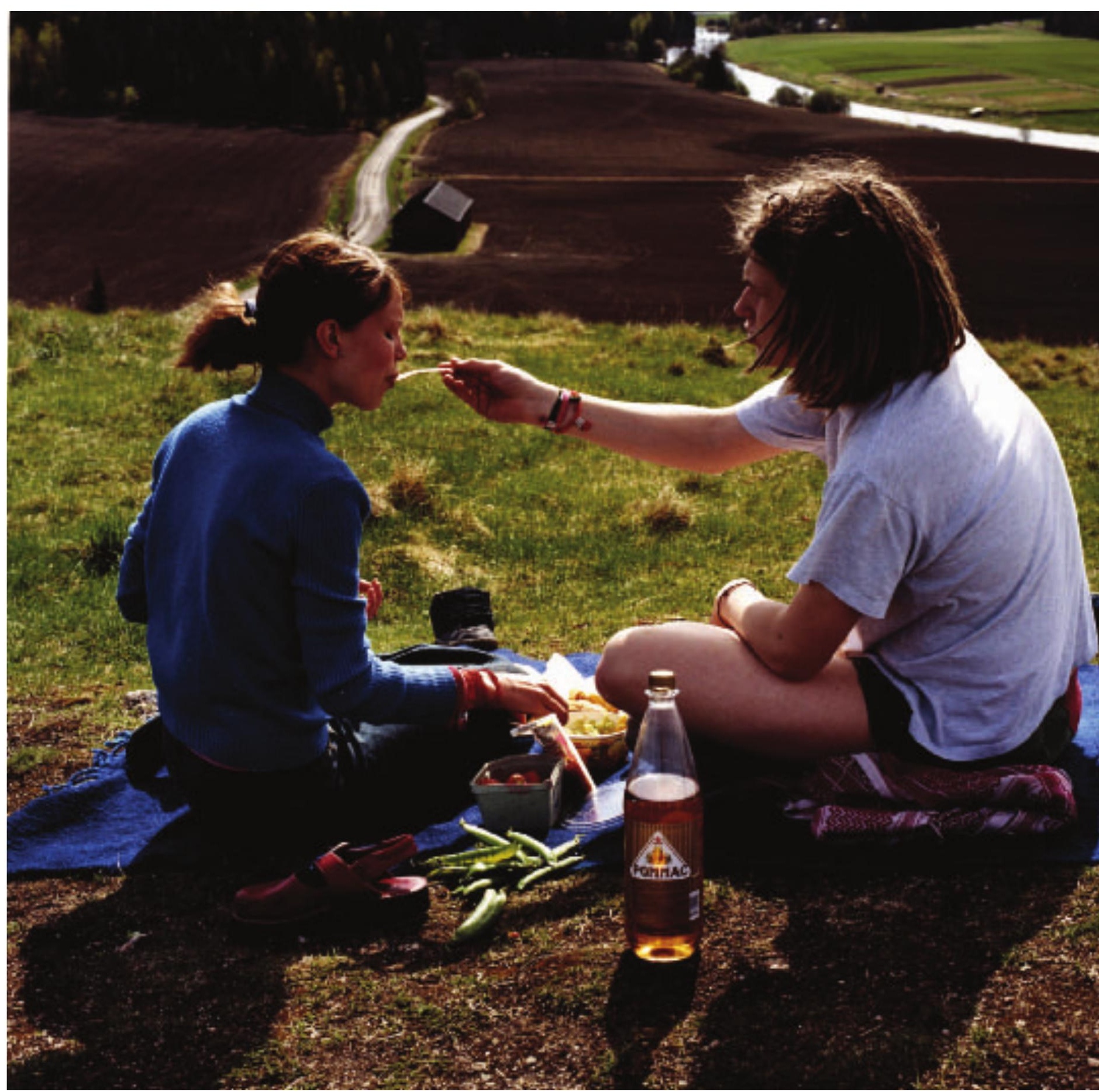

For mange tettsteder og mindre byer er de omkringliggende jordbruksområdene verdifulle for rekreasjon i nærmiljøet. Foto: Tapio Heikkilä 
Alle de nordiske landene satt mål for jordbruket og ivaretakelse av jordbrukslandskap. Den enkeltes mulighet for innflytelse er et viktig prinsipp for arbeidet med jordbrukslandskap, og dette prinsippet er også sentralt i Den europeiske landskapskonvensjonen. Det er sentralt at innsats og tiltak har en bred forankring i samfunnet - hos ulike aktører og på ulike beslutningsnivåer. En drøfting og fastsetting av mer konkrete mål for hva man ønsker å oppnå kan være med å styrke arbei- det lokalt, regionalt, nasjonalt og nordisk/internasjonalt.

En annen utfordring er å legge til rette for at jordbruksnæringen har kunnskap, motivasjon og rammevilkår for å ivareta og utvikle kvaliteter og verdier i jordbrukslandskapet. Utfordringen er også å synliggjøre hva jordbrukslandskapet og jordbruk kan tilby befolkningen.

Vad krävs för att vi medvetet skall utveckla lantbruket i en hållbar riktning? Ja, idag är de flesta överens om att en sådan utveckling förutsätter både etisk medvetenhet, ekologisk varsamhet, social medvetenhet samt teknisk-ekonomisk innovationsförmåga. Jordbruket skall ta fram produkter av hög kvalitet, på ett miljövänligt sätt, till låga priser, samt med acceptabel lönsamhet för lantbrukarna och under en social situation som skapar säkerhet, mening och glädje i arbetet. Detta är ingen enkel uppgift! Situationen försvåras ytterligare av att många aktörer med olika perspektiv och intressen berörs, att en vetenskaplig osäkerhet omöjliggör en tro på enkla lösningar, att rådande maktstrukturer utmanas, samt visar att generella slutsatser om naturens tillstånd är svåra att omsätta i konkreta åtgärder. En situation som lätt leder till handlingsförlamning - vi fortsätter göra som vi alltid gjort. Dagens diskussioner om hur vi kan förvalta kulturlandskapets natur- och kulturvärden belyser frågornas komplexitet och de otal målkonflikter som finns. Komplexiteten och konflikterna är något vi måste lära oss leva med - det handlar om att lära sig hantera dem. Men hur? Magnus Ljung, Sveriges lantbruksuniversitet ${ }^{9}$

\section{Forslag: Mål, prinsipper og politikk}

Kulturlandskapet bør settes på dagsorden politisk, og omfatte dialog mellom politikere på internasjonalt og nordisk nivå så vel som nasjonalt, regionalt og lokalt slik at jordbrukslandskapets utvikling kan tas opp til bred diskusjon. Prosjektet fremmer følgende forslag til mål som grunnlag for videre nordisk innsats:

Variasjonsrikdommen i jordbrukslandskapene i de nordiske landene med natur- og kulturhistoriske verdier skal ivaretas og vedlikeholdes $i$ et langsiktig perspektiv som en ressurs for samfunnet og for den nordiske identitet og utvikling.
Det er store forskjeller i landbrukets forutsetninger i Norden. Både gjennom dette prosjektet og tidligere nordiske prosjekter er det pekt på at landene har felles interesse av å fremme betydningen av kulturlandskap, levende lokalsamfunn, natur- og kulturhistoriske verdier samt verdien av mat og matproduksjon av høy kvalitet. De nordiske landene skulle derfor kunne bidra til at jordbrukets natur- og kulturmiljøer aksepteres som miljøgoder og i internasjonale sammenhenger. De nordiske landene bør arbeide for at internasjonale avtaler og rammevilkår, gir frihet til å utforme en jordbrukspolitikk som bevarer det nordiske jordbrukslandskapet med levende 
lokalsamfunn, natur- og kulturhistoriske verdier og andre kollektive goder.

Følgende hovedgrep foreslås for å styrke nordisk og nasjonal innsats i jordbrukslandskapet:

1. Økt lokal og regional forankring av jordbrukspolitikk og kulturlandskapsarbeid

2. Prioritering av verdiene og fastsetting av konkrete mål

3. Tilrettelegging for verdiskaping med kulturlandskapet som grunnlag

Delegering av beslutningsmyndighet til lokalt og regionalt nivå kan bidra til økt lokal forankring av jordbrukspolitikk og ansvar for kulturlandskapets utvikling ${ }^{10}$. Dette kan sikre $ø k t$ stolthet, medvirkning og eierskap til landskapsverdiene hos befolkningen lokalt og hos bønder som skal produsere ettertraktede kulturlandskap. Ulempene er at nasjonale mål og prioriteringer kan bli vanskeligere å følge opp.

Tiltak og virkemidler bør innrettes slik at de bidrar til samarbeid og dialog om utvikling av jordbrukslandskapet. Et jordbruk som ivaretar landskapshensyn og bidrar aktivt til å produsere miljøgoder, vil trolig utløse mer engasjement i befolkningen.

Prioritering av verdifulle jordbrukslandskap bør gjennomføres som strategi for tildeling av visse økonomiske virkemidler, og for å ivareta økt hensyn til jordbrukslandskapets kvaliteter i areal- og samfunnsplanleggingen. Prioriteringer kan skje gjennom prosesser som sikrer regional og lokal forankring og oppmerksomhet i befolkningen.

Konkrete mål for bevaring og skjøtsel av jordbrukslandskap - lokalt, regionalt og nasjonalt kan også bidra til økt oppmerksomhet og bedre målretting av virkemidler.

Skjøtselsmålene kan også forankres som et ansvar de nordiske landene tar på seg. Det bør være et ansvar lokalt, regionalt og nasjonalt å peke ut verdifulle jordbrukslandskap og sette mål for skjøtsel. Verdifulle områder bør følges opp med strategier som passer for det enkelte område og som holder god kulturminne- og naturfaglig kvalitet.

De nordiske lands forvaltninger bør ta i bruk ulike virkemidler for å utvikle alternative inntekstmuligheter knyttet til nye produkter og tjenester fra landbruk og jordbrukslandskap.

Offentlige midler og eierens innsats er ikke alltid tilstrekkelig til å kunne finansiere skjøtsel og vedlikehold på et ønsket nivå. Andre enn grunneiere/bønder og offentlige instanser bidrar noe til innsats og finansiering $i$ Norden, men i begrenset omfang. Tiltak som kan bidra til at engasjere flere aktører, vil trolig også utløse flere muligheter for annen finansiering. Det kan gi en fordeling av ansvaret for skjøtsel og vedlikehold mellom offentlige og private aktører.

\subsubsection{Kartlegging, overvåking, resultater og dokumentasjon}

Jordbrukslandskapets verdier må komme fram der beslutninger om arealer og landskap tas. Kunnskaper, kommunikasjon og informasjon er stikkord for å få til dette.

Kartlegging av enkeltverdier og landskap er en del av arbeidet med å utvikle kunnskapsgrunnlag og styringsverktøy. For at verdifulle områder skal kunne følges opp med strategier som passer for det enkelte område, trenger både bønder og forvaltning å ha tilgang til stedfestet, ajourført dokumentasjon av verdiene i landskapet.

Kunnskap om landskapsressursene, og hvor sårbare disse er for endringer, er viktig for å

10 En slik delegering av myndighet til regionalt og kommunalt nivå gjennomføres i Norge, jf kap 3. 
kunne forutse og begrense negative effekter av raske landskapsendringer.

Kartlegging er ikke en verdivurdering eller prioritering av landskapet, men kan være et viktig grunnlag for å gjøre det. I denne sammenheng er det viktig å ha i tankene hvordan Landskapskonvensjonen vektlegger betydningen av lokalbefolkningens og "ikkeekspertenes" syn.

Inndeling i landskapsregioner/referansesystemer brukes blant annet som en referanseramme ved arealplanlegging, til ulike prioriteringer, utpeking av verdifulle kulturlandskap og som referanseramme for kartlegging og rapportering.

Det norske Referansesystemet for landskap ${ }^{11}$ og det nyutviklede danske systemet ${ }^{12}$ for landskapskartlegging innebærer begge systematiske metoder for å kartlegge og beskrive landskapskarakter på nasjonalt, regionalt og lokalt nivå.

I Norge er landskapsregioner ferdigbeskrevet på nasjonalt og regionalt nivå. I Danmark prøves metoden ut $\mathrm{i}$ to amt før den operasjonaliseres på nasjonalt nivå. Begge systemer forsøker å unngå verdivurderinger i selve landskapsbeskrivelsene, men beskriver heller egenskapene som gir ulike landskap ulik karakter.

Kartlegging, overvåking og verdivurdering kan gi grunnlag for politikkutforming på ulike nivå, for å kunne prioritere, sette mål, vurdere måloppnåelse og eventuelt gjøre endringer $i$ kursen.
Endringer i landskapet kan følges ved overvåking. Ved overvåking kan politikere og forvaltning vurdere trender og eventuelt møte disse med tiltak på et tidlig tidspunkt. Overvåking gir en systematisk oppfølging av nasjonale og regionale utviklingstendenser i selve landskapet ved hjelp av utvalgte indikatorer.

Heldekkende nykartlegginger og revideringer er mer ressurskrevende og gjennomføres oftest med lang tids mellomrom. Det svenske overvåkingsprogrammet NILS, og det norske overvåkingsprogrammet $3 \mathrm{Q}^{13}$, vil etter planene følge 5 -års intervaller.

En fullstendig resultatkontroll kan bl a baseres på analyser av status, endring, årsak, virkning og respons. Et slikt system for resultatkontroll ligger blant annet til grunn for OECDs rapporteringer.

Overvåking og tilhørende resultatanalyser brukes for å følge med på effekten av tiltak og virkemidler og grad av oppnåelse for miljømål. På denne måten kan man undersøke om de ressurser som settes inn, får den ønskete effekten. Dokumentasjon av effekter er viktig for tilliten mellom befolkningen generelt og landbruksnæringens utøvere. Det kan også gi grunnlag for internasjonale diskusjoner om miljøvirkemidler og jordbruk.

Ved en generell overvåking basert på utvalg, kan spesielt verdifulle områder være svakt representert. Kartlegging og overvåking i "spesielt verdifulle jordbrukslandskap" er også viktig for å sette mål, prioritere, og vurdere virkningen av iverksatt politikk og tiltak og virkemidler i slike områder.

11 Ole Hjort Caspersen, innlegg på workshop, Nordisk kulturlandskapskonferanse, Ulvik, 2003 og Wilhelmutvalget 2002

12 Landskapsregioner i Norge, Nasjonalt referansesystem for landskap. NIJOS 2/98 og 2004 (in prep)

$133 Q$ Tilstandsovervåking og resultatkontroll $i$ jordbrukets kulturlandskap. NIJOS rapport 11/03: 
Forslag: Kartlegging, overvåking, resultater, dokumentasjon

Offentlig forvaltning i de nordiske landene bør ha et ansvar for å tilrettelegge stedfestet informasjon om jordbrukslandskapet i form av kartlegging av verdier, overvåking og dokumentasjon av resultater. Samarbeidet innen Norden er viktig for å utveksle erfaringer og samarbeide om utvikling av indikatorer og metoder og for å analysere og følge opp resultatene for å drøfte om politikk og virkemidler er hensiktsmessige.

Kartleggings- og overvåkingsbehovene i jordbrukslandskapet i Norden varierer, men kan omfatte disse tema:

- Biologisk mangfold på gammel kulturmark og områder påvirket av jordbruket; $\emptyset$ kosystemer, habitater, arter og genressurser hos utvalgte arter,

- Kulturminner, kulturmiljøer og andre kulturhistoriske verdier $\mathrm{f}$ eks; tun, bygninger og anlegg, gamle ferdselsårer, fornminner, lokalhistorie, teknikker, metoder og materialbruk

- Jordbrukslandskapet som helhet; endringer $\mathrm{i}$ arealbruk og eiendomsstruktur, landskapsbilde og gjengroing, stier/ferdselsårer, muligheter og interesse for bruk av jordbrukslandskapet i friluftslivssammenheng.

- Ulike arealinngrep/infrastruktur

\subsection{Jordbruk - landsbygd/ lokalsamfunn - deltakelse}

\subsubsection{Kommunikasjon og motivasjon, ansvar og rollefordeling}

Jordbrukslandskapet gir grunnlag for identitetsbygging og stedsopplevelser. Et steds kultur, folks lokale engasjement og stedstilhørighet har betydning for å se muligheter og lykkes med verdiskaping. Trivsel på et sted kan derfor bidra til en positiv spiralvirkning: skjøtsel og vedlikehold av jordbrukslandskapet -

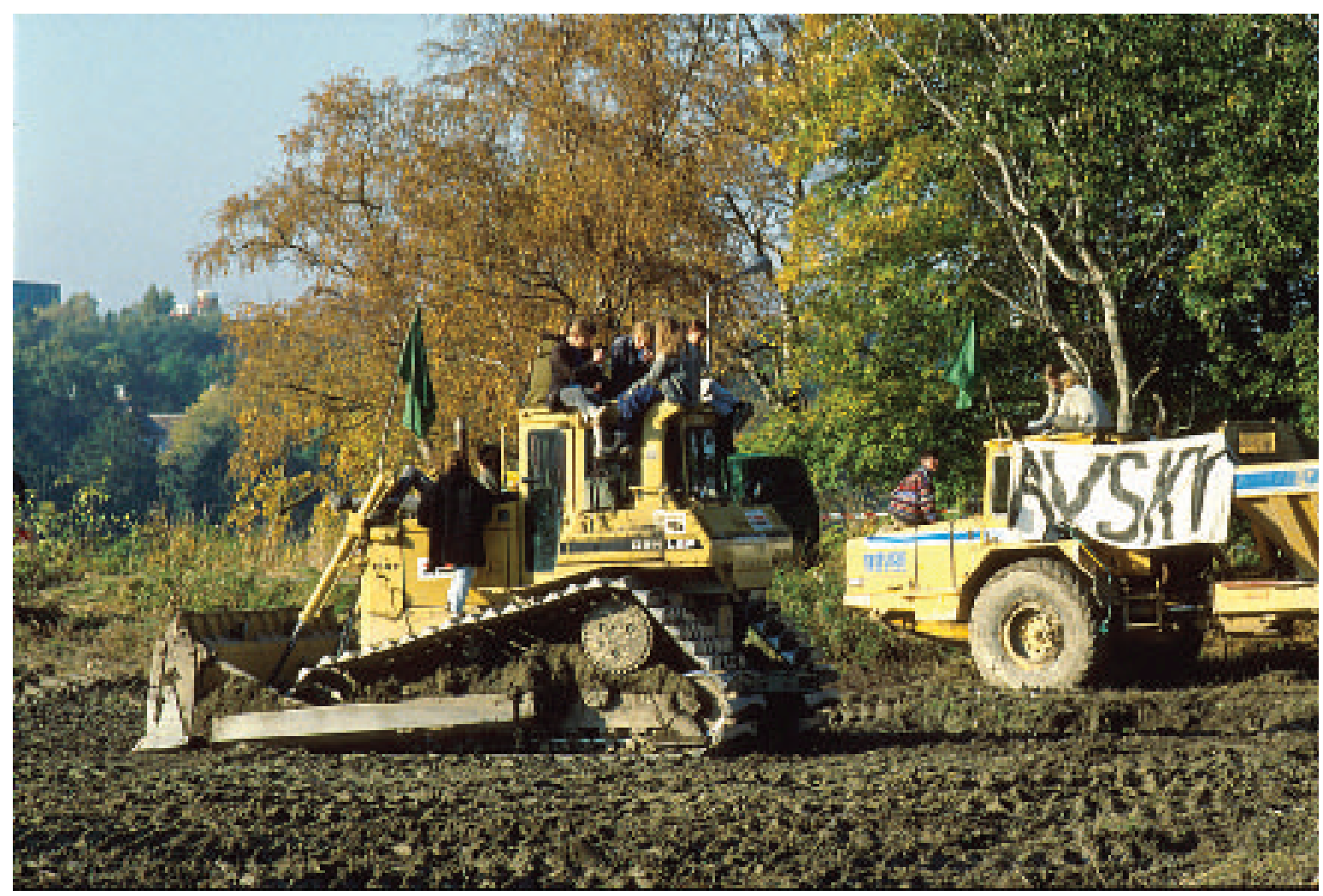

Det er sjelden at folk aksjonerer direkte mot utviklingen $i$ kulturlandskapet. Miljøorganisasjonen Natur og Ungdom $i$ 1991 protesterte mot utbygging $i$ et nasjonalt verdifull kulturlandskap på Rotvoll $i$ Trondheim $i$ over 10 uker. Foto: Oskar Puschmann, NIJOs. 
$ø k t$ interesse for å bo - se muligheter for nye næringer - forbedret skjøtsel -mer trivsel og helhetlige opplevelser - samarbeid om å utvikle attraktive reisemål osv

Beslutninger om jordbruk og arealer er viktige for utviklingen $\mathrm{i}$ jordbrukslandskapet $\mathrm{i}$ et langsiktig perspektiv. Befolkningens og berørte organisasjoners mulighet til å påvirke beslutninger om landskapets utvikling er sentralt i den europeiske landskapskonvensjonen og den nordiske oppfølgingen av denne. Erfaringen er ofte at befolkningen bare engasjerer seg i begrenset grad. Manglende engasjement kan skyldes at aktørene har begrenset mulighet til å se de samlede konsekvenser av enkeltbeslutninger over tid, enten det gjelder arealdisponering eller jordbrukspolitikk.

Aktører, ansvar og rollefordeling

Arbeidet med landbrukets kulturlandskap involverer svært mange aktører. Mulighet for innflytelse og deltakelse kan øke motivasjon, kunnskap og forankring til jordbrukslandskapet. Bedre kontakt mellom ulike sektorer, organisasjoner, næringsliv, institusjoner, befolkningen og media kan bidra til samarbeid og skape allianser. Alle aktørene har et også ansvar for å bidra med sine kunnskaper og innsats. Ved slike oppgaver som krever tverrsektoriell innsats kan ansvaret fort "falle mellom stolene" og erfaringer viser at det kreves god dialog mellom aktørene for å sikre oppfølging av de mest verdifulle områdene.

Jordbrukslandskapet kan ofte bare bli en sak mellom aktørene innen landbruksnæringen og offentlig administrasjon, mens brukerne av landskapet og lokale og regionale politikerne i liten grad blir reelle aktører. Utfordringen er derfor å utløse engasjement, ressurser og kunnskaper hos flere aktører.

Oversikten viser de viktigste aktører og interessenter for arbeidet med jordbrukets kulturlandskap. For aktører i forvaltningen er ulike sektorer og forvaltningsnivåer tatt med. Internasjonale aktører er synliggjort for noen.

1. Kunder og brukere av kulturlandskap - internasjonalt, nasjonalt og lokalt.

a. Befolkningen generelt (lokalbefolkning, folk flest, turister)

b. Organisasjoner og institusjoner (innen miljø, lokalsamfunn/grendelag, kulturminner, naturvern, friluftsliv, historielag, idrett, museer, skoler, kirke $\mathrm{m} f \mathrm{fl})$.

c. Næringsaktører som bruker jordbrukslandskap som ramme (reiseliv, matproduksjon, omsetning og handel, bioenergi, håndverk)

d. Rep for utbyggingsinteresser

2. Landbruksnæringen: Bøndene i form av eiere og utøvere i jordbruket og deres organisasjoner (inkl nordisk-, europeisk- og internasjonal overbygning).

3. Kunnskaps-/fagmiljøer innen forskning, utdanning og rådgivning innen ulike fag og på ulike nivåer

4. Politikere og forvaltning

a. Etter sektorer/- oppgaver:

- Landbruk: jord- og skogbruk, utmark

- Miljøvern: natur- og kulturminnevern, arealplanlegging, friluftsliv 
- Distrikt/landsbygdsutvikling, næringsutvikling, innovasjon, helse og omsorg

- Matforvaltning, næringsmidler

b. Etter beslutnings- og utøvelsesnivåer:

- Internasjonalt: Nordisk råd, Nordisk ministerråd, EU, FN-org., WTO

- Nasjonalt: Storting, regjering, departementer med underliggende etater,

- Regionalt: Regionalpolitikere (fylkesting i Norge), fylkesmenn, fylkesadministrasjonen, regionadministrasjon for sektorene

- Lokalt: Kommunestyre, kommununeadministrasjon (ulike etater og nivå- miljø, landbruk, planlegging/teknisk omsorg, undervisning)

En forutsetning for å opprettholde levende jordbrukslandskaper i de nordiske landene, er at bøndenes aktive rolle som produsenter av både mat og landskap utvikles.

Kulturlandskapet er et resultat av ulike produksjonsformer og kan ikke bevares som en samling enkeltelementer eller organismer, men må ses som en dynamisk helhet. Bøndene må derfor ha hovedansvaret for skjøtsel og vedlikehold av kulturlandskapet.

Samtidig har mange nordiske bønder mest erfaring og utdanning med volumproduksjon av jordbruksvarer. Det samme gjelder ofte landbruksforvaltningen og landbruksforskere. Bøndene opplever også både dobbeltbudskap og motstridende mål fra samfunnet: På den ene side ønsket om lavere priser på mat, på den andre side skjerpes kravene til produksjon og miljø. Omlegging av politikken i retning av mer produksjon av miljøgoder, må ta hensyn til disse forholdene. Veiledning og andre virkemidler for å øke bøndenes og andre aktørers kunnskap er avgjørende for å god kvalitet på miljøtiltakene og for å bidra til næringsutvikling.
Når koblingen mellom bedriften og regionen reduseres, kan også bøndenes interesse for landskapet avta: "Tilsyneladende er den enkelte jordbruger i Danmark på grund af det økonomiske pres mod stadig mere intensiv produktion også mindre motiveret for at bevare bygninger og kulturlandskaber, der ikke direkte bidrager til jordbrugsbedriftens økonomi og overlevelsesevne. Hertil kommer, at jordbrugerens kompetencer og viden om det lokale og regionale kulturlandskab forsvinder hastigt i takt med, at bedrifterne bliver større, jordbrugerne bliver færre og deres mobilitet $ø$ ges...der er ikke er tradition for samarbejde mellem jordbruget og de ideelle aktører og organisationer om beskyttelse af kulturlandskabet..."14 "...Projektet er tænkt som en afprøvning af en ny model for forvaltning af landskabet. Via borgermøter og diskusionsgrupper har lokalbefolkningen kommet med forslag til hvorledes de kunne tænke sig at deres landskab og lokalområde udvikles" 15

14 Lundegren, Jan og Søren Espersen. Notat, workshop, Nordisk kulturlandskapskonferanse, Ulvik 2003

15 Henrik Christiansen. Innlegg, workshop, Nordisk kulturlandskapskonferanse, Ulvik 2003 
"Att skapa och förvalta landskapets natur- och kulturvärden handlar inte om att bestämma vem som har rätt eller fel. Utmaningen ligger i stället $\mathrm{i}$ vår sociala innovationsförmåga, dvs att kunna skapa och tillämpa nya former både bevarande- och förändringsarbetet inom lantbruket. Det är i detta sammanhang som betydelsen av delaktighet och motivation framträder som centrala framgångsfaktorer. Aktuell forskning och praktiska erfarenheter från de nordiska länderna har visat att det konkreta kultur- och naturvårdsarbetet inom lantbruket måste vägledas av ett antal principer. För det första handlar det om att fokusera på lärandet, dvs att hela tiden låta olika perspektiv mötas och komma till tals, framför allt lantbrukarnas egna erfarenheter. För det andra handlar det om att våga lyfta upp målkonflikterna till ytan. Slutligen handlar det om att möjliggöra delaktighet hos alla intressenter.

Varför är då lantbrukarnas och andra aktörers delaktighet så viktigt? Förenklat kan sägas att behovet av ökad delaktighet inom lantbruket baseras på tre argument:

1. Lokal kunskap måste tas till vara, då lösningar ofta är platsspecifika (lantbrukaren säger: "Min kunskap är relevant!")

2. Det är en medborgerlig rättighet att ha möjlighet att ha inflytande över sådant som kommer att påverka ens framtid (lantbrukaren säger: "Jag borde ha något att säga till om!")

3. Delaktighet skapar ökat engagemang och motivation till förändring (lantbrukaren säger: "Att jobba med dessa frågor känns meningsfullt!")

Magnus Ljung, Sveriges landbruksuniversitet ${ }^{16}$

Støtte til jordbruket vil i stadig større grad være avhengig av betalingsvilligheten hos folk i byer og tettsteder, og kanskje også de store aktørene innen bl a næringsmiddelindustri, omsetning og handel. Disse aktørene kan ha lite kjennskap til kulturlandskap, landbruk og landsbygder. For jordbruket blir det derfor viktig å finne aktører som fremmer behov og ønsker med hensyn til jordbruk og landskap.

Lokalsamfunn, frivillige/ideelle organisasjoner, næringsorganisasjoner og fag- og forskningsinstitusjoner kan være en viktig kilde til kunnskap om landskapets historie. Noen steder arrangerer de kurs og dugnader o I som kan bidra til forståelse for å ivareta jordbrukslandskapet, og formidle betydningen av landbruk og landbygdsutvikling.
Med ideelle organisasjoner og aktører menes organisasjoner og enkeltpersoner, som på frivillig basis, arbeider for bevaring og utvikling av kulturlandskap og lokalsamfunn/bygder, jf vedlegg 2. Tradisjonen for at ideelle organisasjoner og lokalsamfunnet tar på seg oppgaver med bevaring av kulturlandskap er ulik i de nordiske landene. I Storbritannia spiller slike organisasjoner ofte en sentral rolle for å finansiere og forvalte historisk viktige og vakre kulturlandskap.

"Hembygds"-foreningene i Sverige har stor betydning for vedlikehold av bygninger og landskap, museal virksomhet, for utvikling og bevaring av servisenivå og utvikling av turisme på landsbygda. De er et eksempel på hvilken rolle slike organisasjoner kan ha. På det politiske plan øver "hembygds"-foreningene innflytelse på lokal og regional planleg- 


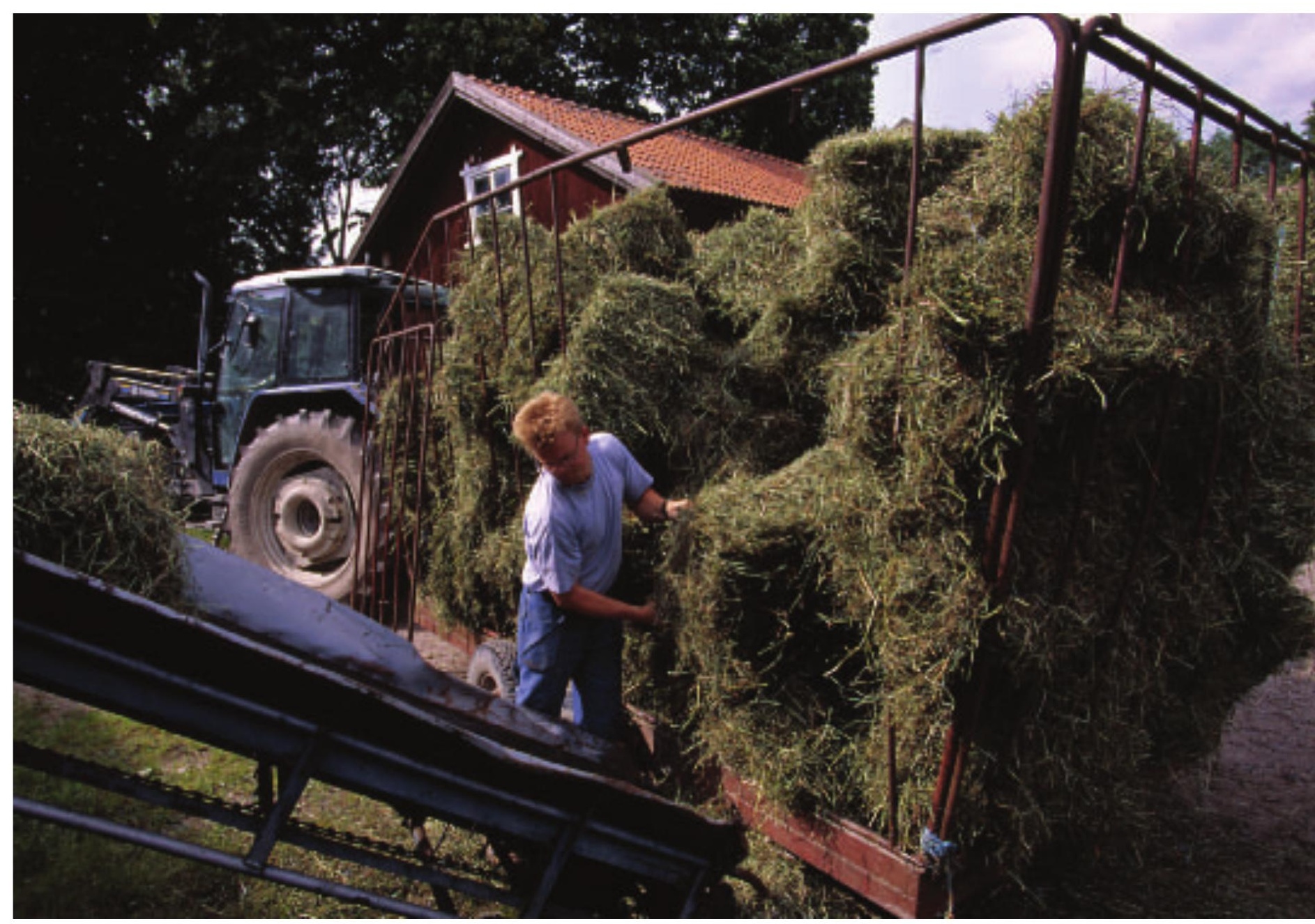

For å opprettholde levende jordbrukslandskaper i de nordiske landene, er det nødvendig at bøndenes aktive rolle som produsenter av både mat og landskap utvikles. Foto: Per G Norèn.

ging, på landbygdspolitikken og på sentrale politikere og statlige myndigheter. Sammen med andre lokale bygdelag og landsbygdsforeninger er de viktige for utvikling og bevaring av lokal identitet og for å opprettholde relasjoner mellom land og by. Oversikt over flere organisasjoner og deres rolle er vist $\mathrm{i}$ vedlegg 3

Generelt har landbruket/jordbrukssektoren fått et økt ansvar for å nå samfunnets miljømål. Det varierer likevel en del mellom de nordiske landene hvordan jordbrukets sektoransvar for miljø ivaretas, hvilke tema det omfatter, samarbeidsrelasjoner mellom sektorene, finansiering av ulike tiltak mm. Det er styrker og svakheter ved at landbruket har fått/får $ø k t$ sektoransvar for miljø. Forbedret samarbeid og felles innsats bør likevel kunne styrke målene om å utvikle bærekraftig jordbruksdrift, utvikle jordbrukslandskapet og natur- og kulturhistoriske verdier og fremme næringsutvikling.

Forslag: Kunnskap og forankring i befolkning, lokalsamfunn, landbruk og organisasjoner En styrket innsats for skjøtsel og vedlikehold landskapet, må legge vekt på å forbedre kunnskap, veiledning og kommunikasjon med bønder og andre aktører om forvaltning av kvalitetene $i$ jordbrukslandskapet.

Det bør derfor være et oppfølgingspunkt for Nordisk ministerråd og de nordiske landene å 


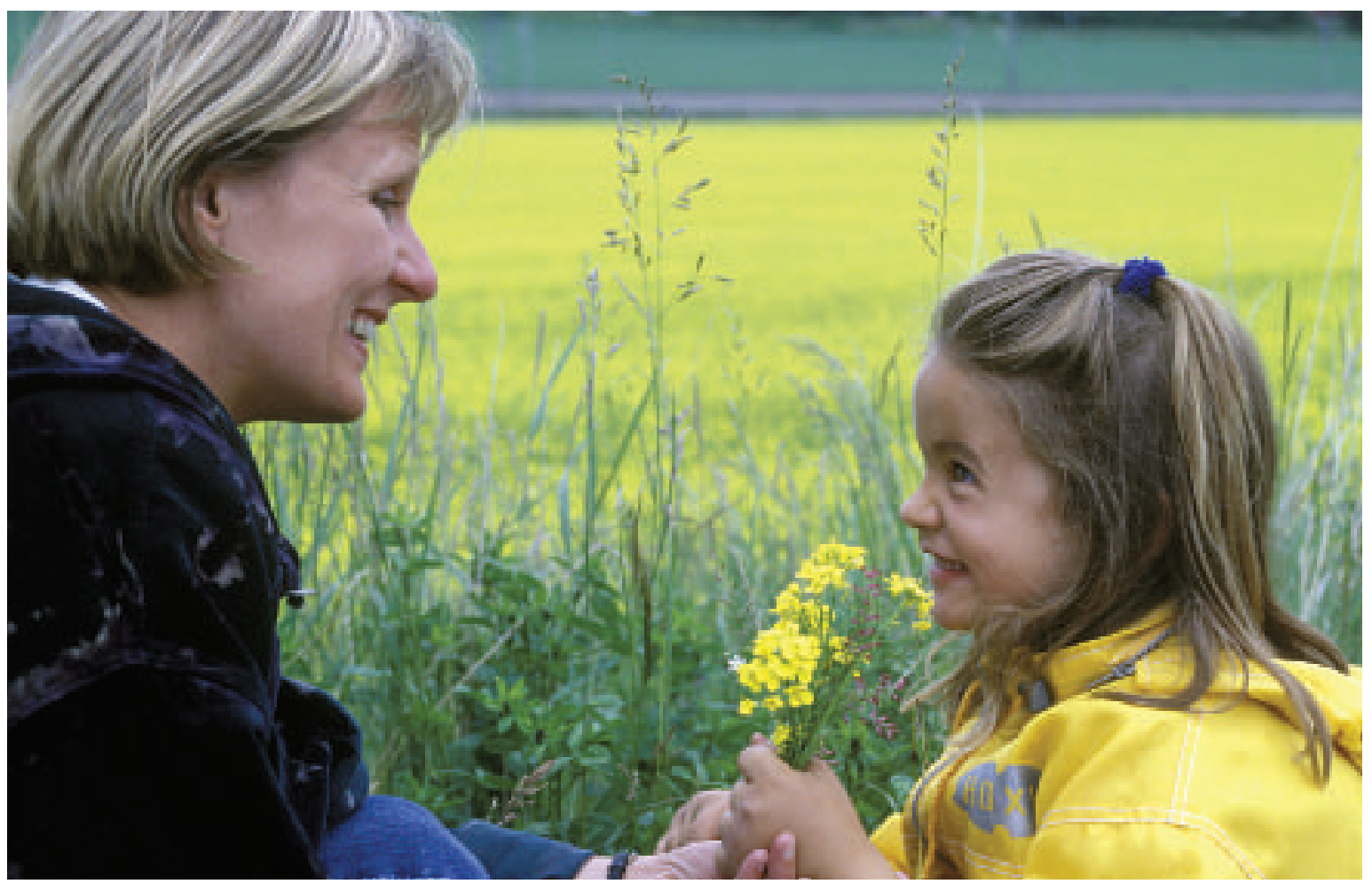

Gode opplevelser i jordbrukslandskapet. Foto: Øystein Søbye, Samfoto.

øke kunnskap, kommunikasjon og bevisstgjøring i samfunnet om kulturlandskap som et produkt av nordisk landbruk og betydningen det har for identitet og trivsel. Hvert av de nordiske land bør også ha som mål å øke bondens kunnskap og stolthet som kulturlandskapsprodusent.

- Utdanningsinstitusjoner på alle nivå og forskningsmiljøer bør vektlegge kunnskap som moderne bønder har behov for som produsenter av både mat og miljøgoder, og som deltakere i utvikling av attraktive landsbygder/distrikter.

- Utdanning innen kulturlandskap og kulturmiljøer bør styrkes, både for forvaltningen og i landbruksutdannelsen. De nordiske landene bør samarbeide om nordisk kunnskapsoppbygging, nettverksbygging og erfaringsutveksling. Det foreslås å utvikle nordiske kurs- og opplæringstilbud for å styrke rådgivningskompetanse om jordbrukslandskap. Eksisterende nordisk samarbeid kan utvikles med utgangspunkt i f eks det nordiske samarbeid på universitets- og høg- skolenivå (NOVA) og det nordiske kurstilbudet om kulturmiljøer.

Det bør tas et nordisk initiativ for å sikre bedre "forbrukerdeltakelse" for utviklingen i jordbrukslandskapet. Organisasjoner og næringer bør involveres i nordiske prosjekter.

Vektleggingen av jordbrukets mangesidige rolle innebærer at ideelle/frivillige organisasjoner og aktører bør få en rolle i utforming av politikk og virkemidler. Lokalnivåets engasjementet, medvirkning og ansvar for jordbrukslandskapet bør økes. Tiltak kan være:

- Bedre kommunikasjon om sammenhengene mellom landskap og jordbruk, trivsel, identitet, bosetting, næringer og muligheter for framtidig utvikling av lokalsamfunnet gjennom $\mathrm{f}$ eks visualisering av ulike scenarier for utvikling.

- Øke reelle muligheter for å påvirke politikk og beslutninger ved å involvere lokalbefolkning og organisasjoner og delegere myndighet til lokalt og regionalt nivå 
- Integrere jordbruk og kulturlandskap som tema i areal- og samfunnsplanlegging.

- Gi befolkningen og organisasjoner mulighet til å delta i konkret landskapsinnsats.

Gjennom det nordisk samarbeidet bør det utvikles nettverk og muligheter for erfaringsutveksling mellom landene på tvers av fag og profesjoner for dette tema. De nordiske samarbeidskanalene for landbruket bør i større grad også omfatte landbrukets fremtidige rolle der kulturlandskap er et viktig produkt av nordisk jordbruk. En videre drøfting og erfaringsutveksling om landbrukets sektoransvar kan inngå i dette.

\subsubsection{Areal- og samfunnsplanlegging - kulturlandskapet som ressurs for identitet og trivsel}

Areal- og kulturlandskapsressursene i jordbruket kan komme under press på grunn av ønsker om bruk av arealene til bolig- og fritidsutbygging, industri, transport, rekreasjon osv. I areal- og samfunnsplanleggingen er det et mål å redusere konfliktnivået ved å kombinere ulike bruksområder og balansere kortsiktige og langsiktige hensyn.

Planleggingslover i de nordiske landene er egnet til å sikre at demokratiske prosesser legges til grunn for beslutninger om bruk av arealene. Men beslutninger som tas, tar ikke nødvendigvis hensyn til langsiktige miljø- og landskapsaspekter. Erfaringer mht til landskapets utvikling er at resultatet kan være utilsiktet når man ser det $\mathrm{i}$ et langsiktig perspektiv. Ved en "bit for bit"-utbygging/utvikling kan landskapet endre fullstendig karakter i løpet av noen år.

Areal- og samfunnsplanleggingen må derfor legge til grunn kunnskap og forhold ved landskapet på stedet; hva som særpreger det, sårbarhet for inngrep, betydning for befolkningen og fremtidig potensial for næring og trivsel. Både samfunnets og landbrukets arealdisponering har betydning for utviklingen i jordbrukslandskapet.

\section{Forslag: Jordbrukslandskapet i areal- og samfunnsplanlegging} Jordbrukslandskap og jordbrukets natur- og kulturarv bør inngå som et vesentlig element i landsbygdspolitikk og stedsutvikling. En klassifisering og verdisetting av jordbruksarealer og kulturlandskap som viser de viktigste områdene i kommunen, kan være et ledd i dette 17.

\section{Utvikling av verdiene i jordbrukslandskapet} bør forankres i lokale og regionale planprosesser. Nybygg og anlegg innen jordbruket bør også være tilpasset landskap og byggeskikk. Det foreslås å utveksle erfaringer om disse tema i Norden.

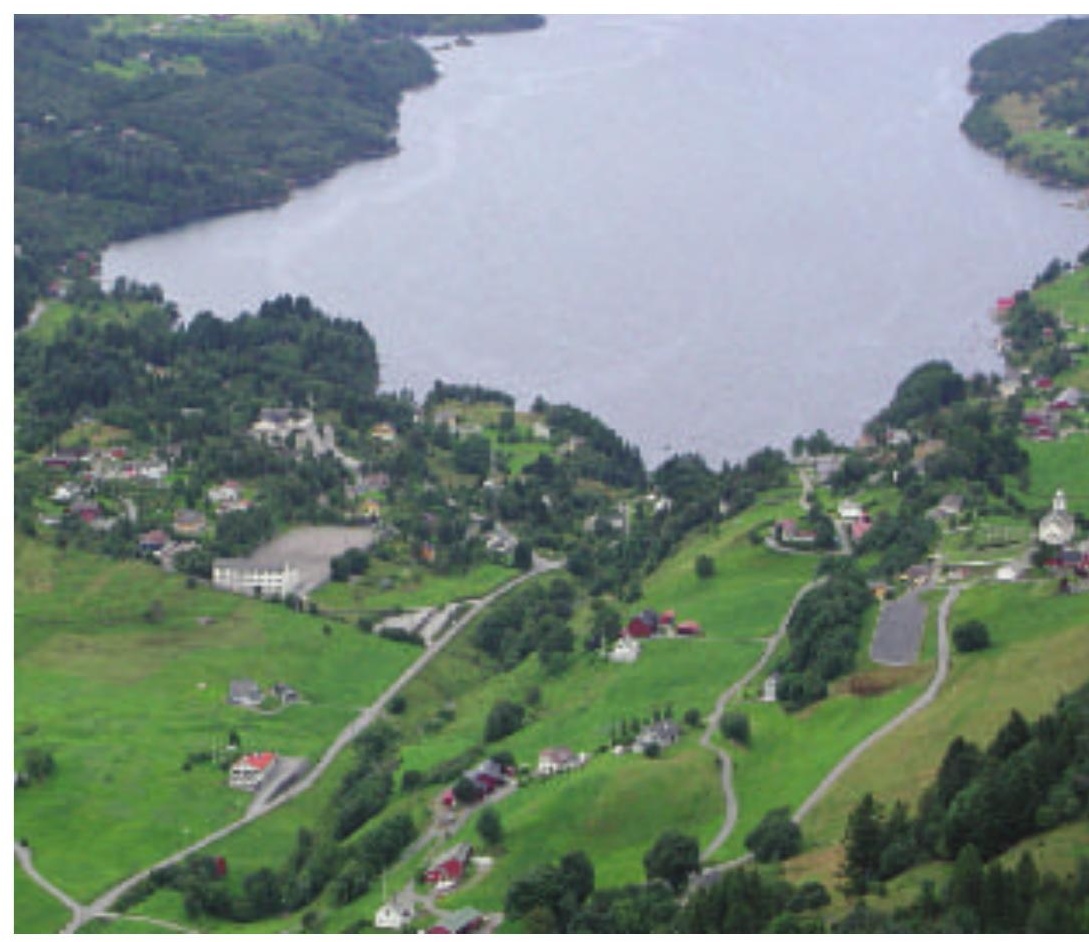

Areal- og kulturlandskapsressursene $i$ jordbruket kan komme under press på grunn av bruk av arealene til bolig- og fritidsutbygging, industri, transport, rekreasjon osv. Foto: Ole Bakkebø. 


\subsection{Skjøtsel, vedlikehold og forvaltning av jordbrukslandskap}

I Norden videreføres fortsatt ulike driftsformer med lange tradisjoner mange steder. Disse områdene er ofte kjennetegnet ved et mangfold av kulturminner, stor variasjon i kulturmarker med kulturbetingete naturtyper og plante- og dyrearter som er unike også internasjonalt. Slike landskap viser historie om bruken av naturressursene i de enkelte nordiske land, og er samtidig et bidrag til
Europas og verdens natur- og kulturarv.

Jordbrukslandskapet er i stor grad et resultat av måten jordbruksproduksjonen foregår på. Dersom skjøtsel av kulturlandskapet skal kunne være en grunnlagsinvestering for landsbygder og nye næringer, må det legges vekt på at innsatsen i kulturlandskap og miljøvennlige produksjoner kan gi inntekter. Muligheter for bruk av naturbeiter er særlig viktig.

Under perioden 1995-2002 ökade arealen betesmark i Sverige från 450000 till 490000 ha. Ökningen är positiv för natur- och kulturvärden och förstärker möjligheterna att nå miljökvalitetsmålen. Den positiva utvecklingen kan antas bero på ekonomiska drivkrafter både inom och utanför ramen för LBU-programmet. Exempelvis så gynnar Agenda 2000 produktion av stutar, vilket ökar tillgången på betesdjur. Med hjälp av LBU-programmets miljöersättningar för skötsel av betesmarker ökar intresset för att släppa djuren i naturbetesmarker i stället för på betesvall. Dess värre är tillgången på betesdjur mycket olika i olika delar av landet vilket försvårar upprätthållandet av hävden i många områden.

Idag omfattas ca $80 \%$ av betesmarksarealen av miljöersättningen för bevarande av betesmarker. Andra undersökningar visar att ungefär $70 \%$ av de objekt som pekades ut i ängsoch hagmarksinventeringen under första halvan av 1990-talet nu är ansluten till miljöersättningarna.

Slåtterängsarealen i Sverige ökar och förväntas att under 2003 överstiga 7000 ha. Ersättning till återskapande av slåtterängar omfattade 1000 ha år 2001.

Mer än 10000 brukare har anslutit sig till miljöersättningen för bevarande av värdefulla natur- och kulturmiljöer. Det innebär att brukarna förbundit sig att sköta samtliga utpekade landskapselement $\mathrm{i}$ anslutning till åkermark. Exempel på sådana landskapselement är fornlämningar, alléer, stenmurar och åkerholmar. Jordbruksverket, Sverige

Husdyras rolle i kulturlandskapet bør vies særlig oppmerksomhet ${ }^{18}$ :

- Beitedyr er viktig for å bevare et åpent landskapsbilde i rekreasjons- og friluftsområder

- Viktige biotoper og gammel kulturmark kan være avhengig av beite med ulike husdyr for å ivareta plante- og dyreliv og for å gjennom beite synliggjøre kulturminner.
- Husdyr er viktige kontaktskapere mellom landbruket og befolkningen ellers

- Det er et potensial for næringsutvikling med utgangspunkt i ulike husdyr og husdyrraser. Beitedyr kan $f$ eks brukes som ledd i produksjon av kvalitetsvirke fra løvtrær.

18 Nesheim, Norderhaug, Ihse: Beiting $i$ kulturlandskap, rapport fra nordisk seminar $i$ Natadal. Planteforsk 52/2002 


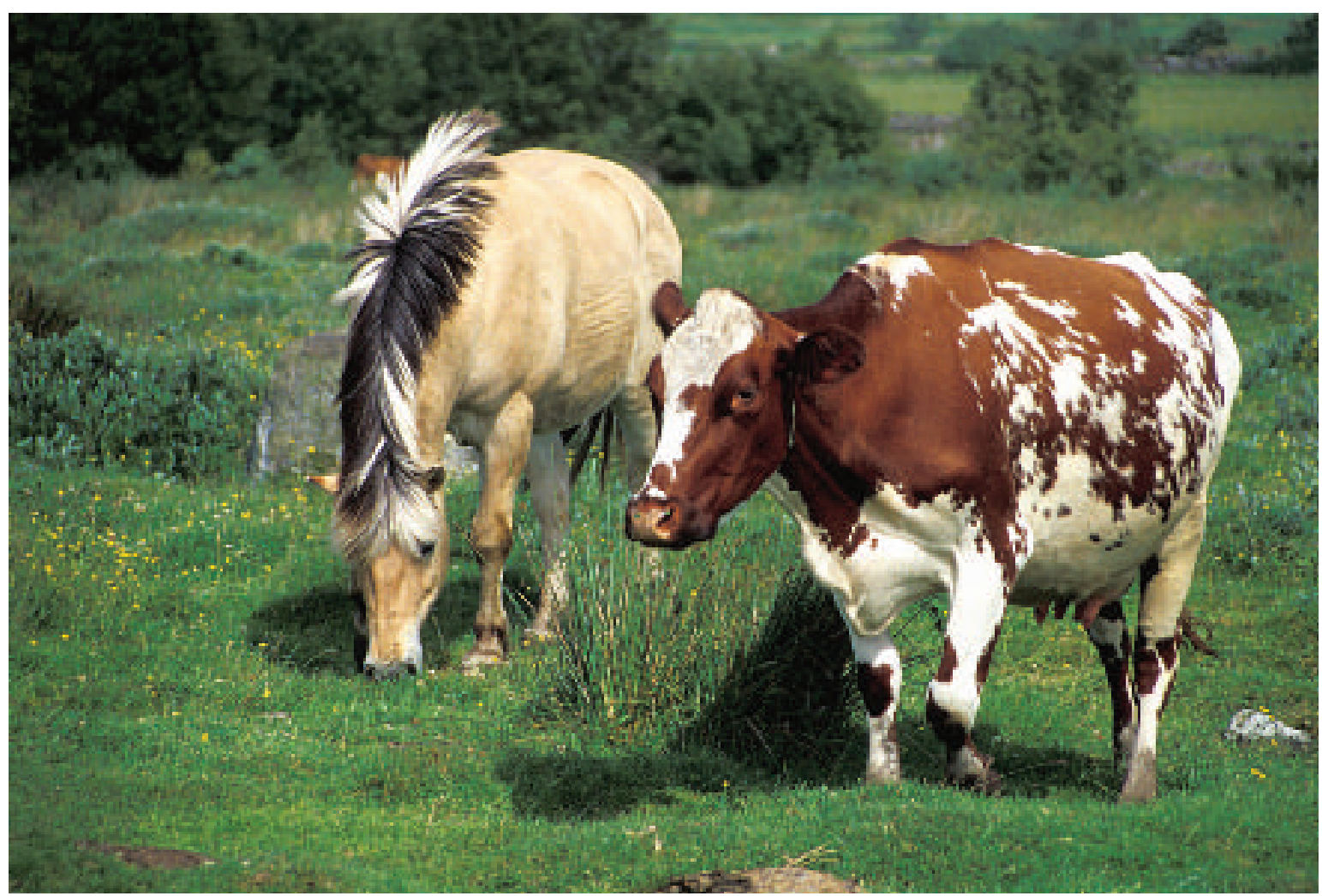

Husdyra holder landskapet åpent ved beite og bidrar til økt biologisk mangfold og oppleves av folk flest som positive innslag i jordbrukslandskapet. Foto: Oskar Puschmann, NIJOs.

En svensk utredning viste nylig at ulike virksomheter med hest var den fjerde største inntektskilden i landbruket, på nivå med produksjon av storfekjøtt. Hesten en ressurs for miljøvern og landsbygdsutvikling. Den kan brukes til landskapsskjøtsel og skaper kontaktflater mellom by/tettsted og landsbygd.

For verdifulle jordbrukslandskap er det et poeng at skjøtsel, restaurering og vedlikehold gjennomføres på en tradisjonell eller tilnærmet tradisjonell måte, slik at også kunnskapen om driftsmåter, håndverksteknikker og materialbruk videreføres. God kvalitet på skjøtsel og vedlikehold kan øke potensialet med hensyn til bruk av området i verdiskaping.

Forvaltningen av de mest verdifulle kulturlandskapene er til dels vært preget av at ingen aktør tar tilstrekkelig ansvar for forvaltning av områdene. Årsakene til dette kan være flere; landbruksdrifta kan ha opphørt, kostnadene til skjøtsel og vedlikehold er store og det er behov for ressurspersoner som både kan motivere og følge opp faglig.

\section{Forslag: Skjøtsel og vedlikehold av jordbruks- landskapet}

De nordiske landene bør sikre skjøtsel og vedlikehold av jordbrukslandskapet som ivaretar landskapsbilde, biologisk mangfold, kulturhistoriske verdier og muligheter for friluftsliv og opplevelser. Landene bør arbeide for å få aksept for at helhetlig jordbruksproduksjon består av både mat og landskap.

Jordbrukets kulturlandskap bør i størst mulig grad ivaretas innenfor rammen av et aktivt, økonomisk levedyktig landbruk som er tilpasset de natur- og kulturhistoriske verdiene. Dette forutsetter at det er økonomisk interessant og praktisk mulig for nordiske bønder å skjøtte både vanlige og spesielle jordbruks- 
landskap. Rammevilkårene for jordbruket må derfor sikre:

a) at det tas generelle hensyn i jordbruksdrifta og ved nybygging/anlegg,

b) sikre kontinuitet i "kvalitetsskjøtsel" av særlig verdifulle jordbrukslandskap som er tilpasset jordbrukslandskapet som helhet, biologisk mangfold og kulturminner. Tiltak kan være:

- Stimulere til skjøtsel som en integrert del av landbruksdrifta

- Stimulere til lokalt engasjement og bruke alliansepartnere for sikre skjøtsel av nasjonalt, regionalt og lokalt viktige områder.

- Kommunikasjonen mellom forvaltningen og den enkelte bonde om skjøtsel av særlig verdifulle områder bør styrkes.

- Arbeide med å finne flere finansieringskilder for skjøtsel. Ansvaret for særlige verdifulle områder bør ligge i forvaltningen. Områdene trenger en helhetlig og kvalitetssikret forvaltning der det inngås avtale om skjøtsel i samarbeid med eier/bruker.

c) skjøtsel av prioriterte større områder i jordbrukslandskapet, der tiltak kan være:

- I områder hvor gjengroing er en hovedutfordring, bør det utarbeides lokale- eller regionale strategier og prioriteringer.

- Styrke tiltak og virkemidler for å sikre beiting av naturbeiter i inn- og utmark. Det trengs kunnskap om lønnsomheten ved bruk av ulike beiter, de ulike dyreslagenes beiteegenskaper ved ulik vegetasjon og effekter av ulike virkemidler. De gamle husdyrrasenes egenskaper som beitedyr i kulturlandskapet er en del av dette.

- Styrke hestens rolle som beitedyr og kontaktskaper mellom by og land både nordisk og nasjonalt.

- Bidra til at virkemidler innen skog og bioenergi sees i sammenheng med kulturlandskap og næringsutvikling.

- Tilrettelegging for ferdsel $\mathrm{i}$ jordbrukslandskapet er et viktig tiltak for å øke befolkningens muligheter for friluftsliv, opplevelser og rekreasjon i nærmiljøet og for å øke kontakten mellom landbruk og lokalsamfunn.

Det kan drøftes om det enkelte nordiske land bør ta på seg et særskilt ansvar for visse jordbrukslandskap og om det kan gjennomføres en nordisk prosess med utpeking av verdifulle landskap. Slike prosesser er krevende, men kan eventuelt inngå i det pågående nordiske samarbeidet om "World Heritage"-områder. Det kan være aktuelt å plukke ut noen modellområder i Norden som en nordisk referanse $i$ et europeisk og globalt perspektiv.

\subsection{Jordbrukslandskapet - grunnlag for næringsutvikling (og omvendt)}

Et vakkert landskap lar seg i liten grad omsette i et marked. Jordbrukslandskapet kan likevel danne et utgangspunkt eller være en ramme for en rekke ulike typer vare- og tjenesteproduksjoner som lar seg omsette i markedet. Næringsutvikling kan skje ut ifra en direkte forankring i kulturlandskapsverdier, eller kulturlandskapet kan være en ramme for andre næringer mer indirekte.

Kulturlandskapet kan også gi mulighet for å skape et bedre inntektsgrunnlag både innen landbruket og i lokalsamfunnet som helhet.

Næringsutvikling er et ledd $\mathrm{i}$ å sikre bosetting og inntekter i landbruket. Samtidig har aktive bygder også best forutsetninger for å drive med ulike typer næringsutvikling.

Lokal næringsvirksomhet knyttet til landbruket, kan øke kontakten med befolkningen for $\emptyset$ vrig. Dette kan derfor også fungere som en kanal for befolkningens etterspørsel etter andre produkter/tjenester. Det kan være målkonflikter mellom bevaring av verdier i jordbrukslandskapet og tilrettelegging for verdiskaping dersom det ikke tas tilstrekkelig hensyn. Næringsutvikling bør ha et langsiktig perspektiv for øye, slik at ikke framtidas potensial for verdiskaping "brukes opp". 


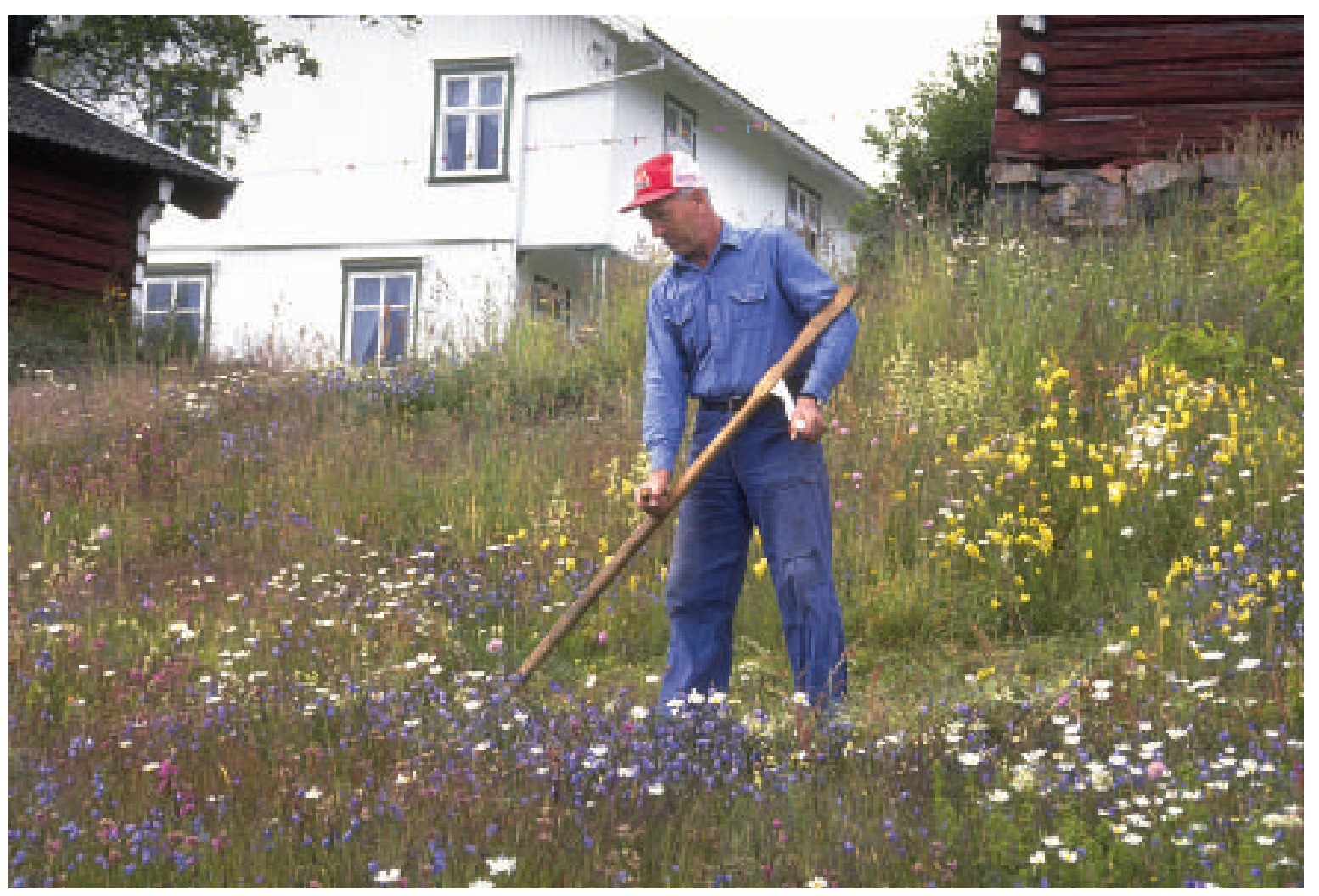

"Kvalitetsskjøtsel" av særlig verdifull kulturmark. Foto: Oskar Puschmann, NIJOs.

Det er et stort potensial for mange ulike næringer med basis i jordbrukets kulturlandskap:

- Reiseliv, servering og fritid: Her finnes den tetteste koblingen mellom næring og kulturlandskap, men inntektene er vanskelige å føre tilbake til de som skjøtter landskapet.

- Lokal produkter og -foredling: Landskapet kan gi produktene en identitet, en tilknytning til et sted og en historisk ramme som kan presenteres som en del av produktets kvalitet.

- Lokale husdyrraser og sorter/arter av dyrka planter er også et ledd i å sikre biologisk mangfold, ivareta kulturarv og skjøtte landskapet. De gir muligheter for næringsutvikling ved en kombinasjon mellom lokal matkultur og kulturlandskap.

- Bioenergi og kvalitetsmaterialer: Kombinasjon av skogskjøtsel og åpning av gjengrodde arealer med effektiv bruk av bioenergi. Materialer til verdifulle bygninger og anlegg.

- Besøksgårder, grønn omsorg, helsetiltak, rekreasjons- og fritidstilbud: I form av tjenester som det er marked for.

- Kunnskapsoppbygging og praktisk kunnskap i landskapsskjøtsel: Guiding, tematurer, slåtte- og botanikkurs mv mot betaling. 


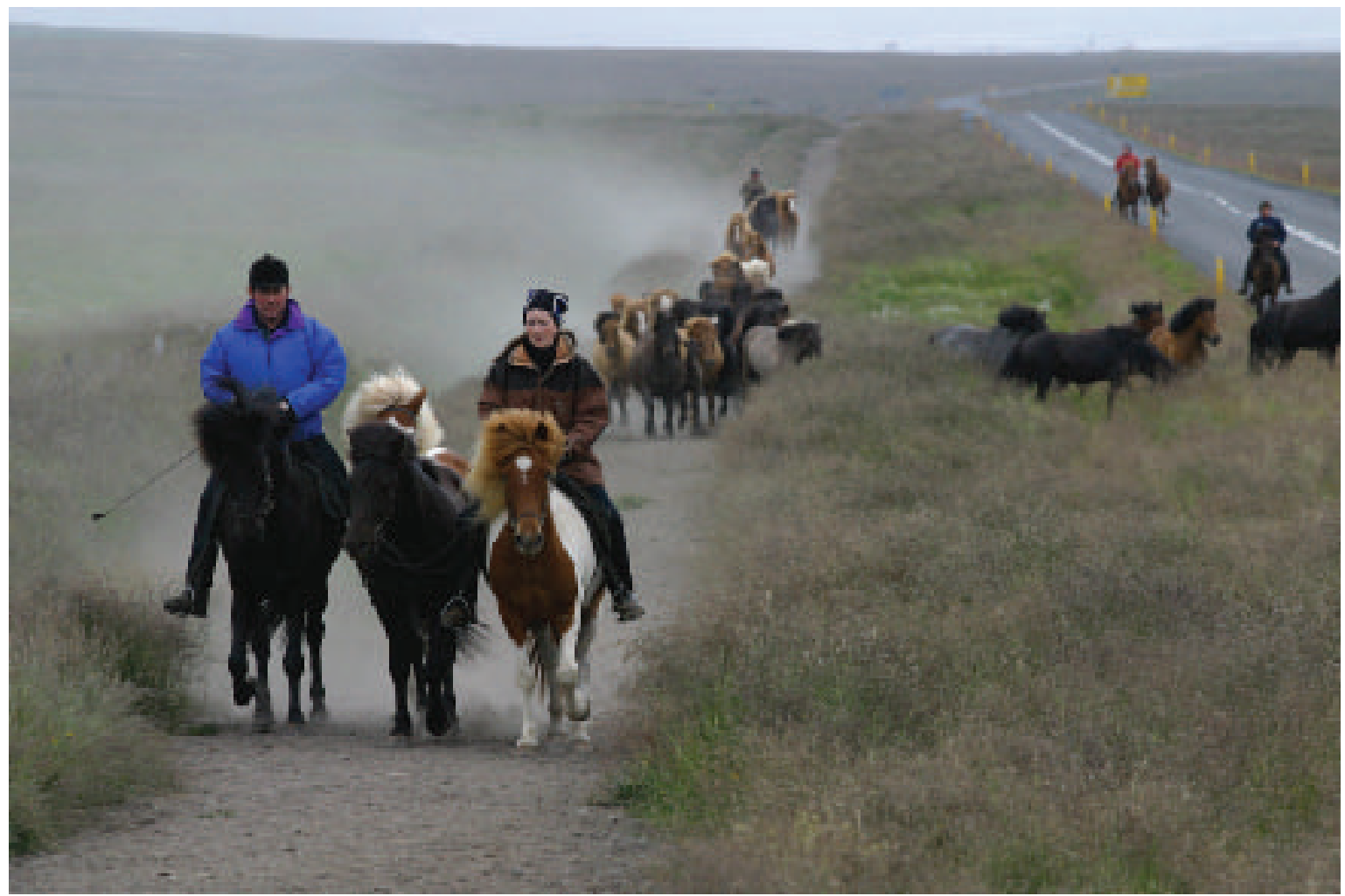

Ridning i historisk jordbrukslandskap trekker turister til Island. Foto: Anna Fjóla Gísladóttir

Satsing på næringsutvikling forutsetter kunnskaper og personlige egenskaper hos den/de som skal investere og drive. I tillegg er rammevilkår som $\mathrm{f}$ eks sosiale og kulturelle forhold i lokalsamfunnet, støtte og hjelp fra myndigheter og andre svært viktig. Satsing på nye næringer innebærer risiko både for den enkelte og for det offentlige. Fokus på kunnskaper og tiltak som kan redusere risiko er sentralt.

Det er bare fantasien og rammevilkårene i samfunnet som setter grenser for mulighetene for næringsutvikling. Nettopp det at næringsutvikling forutsetter kreativitet, evne til å finne nye nisjer og en viss vilje til risiko, gjør det krevende for forvaltningen å finne gode virkemidler .

Erfaringene fra de nordiske landene er begrensede når det gjelder muligheter for å utvikle og få avsetning for nye, regionale og alternative produkter. Varer som ikke produseres året rundt, $i$ små mengder eller med varierende kvaliteten kan være vanskelig å omsette gjennom de store kjedene. De store selskapenes eksklusive avtaler er en utfordring for både nisjeproduksjoner og småskala reiseliv. Forvaltningens rolle bør derfor være innsats og initiativer for å koble ulike aktører, fremme infrastruktur og fjerne flaskehalser $\mathrm{i}$ verdikjedene.

\section{Forslag: Jordbrukslandskapet som "merke- vare" for verdiskaping og lokalsamfunn} Næringsutvikling knyttet til jordbrukslandskapet i Norden er i flere sammenhenger pekt ut som et aktuelt tema for nordisk samarbeid ${ }^{19}$. Det offentlige må satses mer på å utvikle kanalene for omsetning av nisjeprodukter.

For å bevare og utvikle helhetlige jordbruks-

19 se vedlegg 1: Nord 2000:18 Jordbrukslandskapets kulturverdier - utfordringer $i$ et tverrsektorelt samarbeid og Seminarrapport om samme tema, Hurdal, Norge 2001. 
produksjoner er det viktig å se ulike tiltak i sammenheng med utvikling av landsbygdspolitikken. Landskap og jordbrukets natur- og kulturarv bør inngå som et vesentlig element i landsbygdspolitikk og stedsutvikling.

Det foreslås at nordisk samarbeid og erfaringsutveksling kan omfatte næringsutvikling med grunnlag $i$ jordbrukslandskap og naturog kulturarv. Forslag til tema:

- Erfaringsutveksling med fokus på hele "varekjeden". Praktiske tiltak innen både kulturlandskap og næringsutvikling.

- Virkemidler for å fremme nye næringer og godtgjørelse for produksjon av kollektive goder. Avdekke insentiver som er viktig for å utvikle lokale produkter.
- Øke bevisstheten blant aktørene både innen og utenom landbruket om kulturlandskap som grunnlag for næringsutvikling.

- Lokale modeller for mer forpliktende samhandling mellom reiselivs- og landbruksnæringa. Hvordan skape grunnlag for vinnvinn-situasjoner?

- Lære av områder som har erfaring i å "selge" kulturlandskapet som en del av produktene.

- Modeller og avtaler for skjøtsel av jordbrukslandskap som grunnlag for næring

- Initiere forskning som belyser reiselivets avhengighet av de kollektive godene som skapes av landbruk og lokalsamfunn. 


\section{Prosjektets anbefalinger}

Dette kapitlet inneholder prosjektets prioriterte anbefalinger i form av forslag til mål, strategier og tiltak for å utvikle og fremme nordiske jordbrukslandskap som en ressurs for samfunnet.

\section{Til Nordisk ministerråd og de nordiske lands myndigheter:}

Forslag til mål:

Variasjonsrikdommen i jordbrukslandskapene i de nordiske landene med naturog kulturhistoriske verdier skal ivaretas og vedlikeholdes $i$ et langsiktig perspektiv som en ressurs for samfunnet og for den nordiske identitet og utvikling.

\section{Nordisk samarbeid for å fremme jordbruks-} landskapets verdier $\mathrm{i}$ internasjonal sammenheng bør styrkes.

1. De nordiske landene bør bidra til at jordbrukslandskapet og dets natur og kulturhistoriske verdier settes på dagsorden $\mathrm{i}$ internasjonalt samarbeid både faglig og politisk.

2. De nordiske landene bør arbeide for at internasjonale avtaler og -rammevilkår, gir frihet til å utforme en jordbrukspolitikk som bevarer det nordiske jordbrukslandskapet med levende lokalsamfunn, naturog kulturhistoriske verdier og andre kollektive goder.

Innsatsen for å bevare og fremme samfunnsverdier knyttet til jordbrukslandskapet bør styrkes.

3. De nordiske landene bør styrke arbeidet med informasjon, kommunikasjon, og kunnskapsutvikling om jordbrukslandskapets verdier og muligheter og søke å få en diskusjon i samfunnet om framtidas jordbrukslandskap.

- Det nordiske samarbeidet på dette tema bør styrkes ved hjelp av erfaringsutveksling, nettverksbygging og utarbeiding av en handlingsplan. Samarbeid bør bidra til å synliggjøre og forsterke innsatsen for å fremme landbrukets og jordbrukslandskapets positive bidrag til samfunnet $i$ form av natur- og kulturhistoriske verdier, levende landsbygd, muligheter for opplevelser og friluftsliv og grunnlag for andre næringer.

- Målet for informasjons- og holdningsarbeid bør også være å øke samarbeidet lokalt mellom allmennheten, landbruksnæringen, andre næringer, forvaltningen, fagfolk, ulike organisasjoner, skoler og andre institusjoner.

- Kunnskapsgrunnlaget i Norden og det enkelte land bør forbedres gjennom nordisk samarbeid om undervisning og kurs, forskning, kartlegging og overvåking.

- Arbeidet for å øke bøndenes stolthet og kunnskaper som produsenter av miljøgoder knyttet til jordbrukslandskapet bør styrkes i Norden.

4. Nordisk ministerråd og de nordiske land bør styrke fokus på jordbrukslandskapet som ressurs for identitet og trivsel og som potensial for nye næringer.

- Skjøtsel og bevaring av jordbrukslandskapet bør ivaretas ved å sikre rammevilkår og gi muligheter for miljøvennlig jordbruk og andre næringer og for bosetting på landsbygda. 
- Jordbrukslandskapet kan bli en "merkevare" for næringer og lokalsamfunn. Nye næringer med basis i jordbrukets kulturlandskap kan bidra til å forbedre inntektsgrunnlag og fremme bosetting i distriktene. En engasjert lokalbefolkning og beitedyr er viktige ressurser for å sikre skjøtsel og bevaring av jordbrukslandskapet. Landbruket, andre næringer og lokalsamfunn må se mulighetene for nye næringer og ta dem i bruk. Forvaltningen bør legge til rette gjennom ulike rammevilkår og samordning mellom ulike virkemidler.

- De nordiske landene bør være pådrivere i arbeidet med å stimulere skjøtsel og bevaring av særlig verdifulle jordbrukslandskap og øke kunnskapene om disse områdene.

- Landbruksnæringen har selv et ansvar for å fremme positive effekter av jordbruksdrift og redusere negative. Næringen bør utfordres til å svare på samfunnets etterspørsel etter landskapskvaliteter, opplevelser og produkter fra jordbrukslandskapet. En viktig strategi er å målrette skjøtsel og vedlikehold for å sikre trua og sårbare arter og naturtyper, freda og verneverdige landbruksbebyggelse og andre kulturminner, jordbrukslandskapet som helhet og muligheter for friluftsliv og rekreasjon.

5. Nordisk ministerråd og de nordiske land bør bidra til at areal- og samfunnsplanlegging ivaretar helhetlige jordbrukslandskap $i$ et langsiktig perspektiv

- Befolkningen og berørte organisasjoner bør få økt mulighet til å påvirke beslutninger om jordbrukslandskapets utvikling.

- Ved arealplanlegging og arealdisponering til utbyggingsformål bør hensynet til de langsiktige verdiene i jordbrukslandskapet, integreres i beslutningene. De nordiske land bør utveksle erfaringer om kunnskapsgrunnlag, virkemidler og prosesser som kan sikre dette.
6. Anbefalingene i tidligere nordiske rapporter bør videreføres, jf vedlegg

- Forprosjekt for oppfølging av den europeiske landskapskonvensjonen, TemaNord 2003:550, bør ligge til grunn for landbrukssektorens satsinger på jordbrukslandskapet.

\section{Forslag til prioriterte tiltak for nordisk samarbeid (ikke prioritert rekkefølge)}

\section{Det foreslås:}

a) å utvikle en nordisk handlingsplan for samarbeidet om jordbrukets kulturlandskap som kan bidra til å styrke kunnskaps- og erfaringsutveksling og nettverksbygging på tvers av landegrenser, sektorer, organisasjoner og institusjoner i Norden. Handlingsprogrammet må omfatte en vurdering av aktuelle arenaer, tema og målgrupper som er viktige for å få utviklingen i jordbrukslandskapet på dagsorden på ulike nivåer. Tiltakene nedenfor kan eventuelt inngå i handlingsplanen:

b) et løpende nordisk forum/samarbeid for å utveksle og spre erfaringer med kartlegging og overvåking, jordbrukslandskap i lokale og regionale planprosesser og bruk av jordbrukslandskapet i næringsutvikling.

c) å utveksle erfaringer om organiseringen og fordelingen av ansvar for jordbrukslandskapet og de natur- og kulturhistoriske verdiene mellom sektorene på nordisk plan og i det enkelte land.

d) at de nordiske landene bør arbeide for at tiltak og virkemidler innen jordbruk-, skogbruk- og bioenergi og landsbygdsutvikling ses i sammenheng for å bidra til målrettet skjøtsel.

e) å bidra til tverrvitenskapelig forskning om jordbrukslandskapet som kan kombinere naturvitenskapelig og humanistisk tenkning og bidra til kunnskap om økonomi, næringsspørsmål eller natur- og kulturmiljøaspekter knyttet til jordbrukslandskapets utvikling. Slike temaer bør kunne egne seg for nordisk forskningssamarbeid. 
f) å utveksle erfaringer om informasjons- og holdningsarbeid og utvikle nordiske kursog opplæringstilbud på universitets- og høgskolenivå for å styrke kunnskap og rådgivning om jordbrukslandskap hos ulike målgrupper.

g) et nordisk arbeid som kan illustrere utvikling og vise mulige scenarier for jordbrukets kulturlandskap, jf kap 5.2. h) en spørreundersøkelse som kan gjennomføres i flere nordiske land om holdninger til jordbrukslandskap, natur- og kulturhistoriske verdier for ulike befolkningsgrupper. 


\section{Litteratur og henvisninger}

Arbeids- og administrasjonsdepartementet 2003. Om jordbruksoppgjøret 2003. St prp nr 70 (2002-2003). Oslo

Caspersen, Ole Hjort 2003. Landskabskortlægning i Danmark.

Forskningscenter for Skov \& Landskab, Danmark. Innlegg på workshop, Nordisk kulturlandskapskonferanse, Ulvik

Christiansen, Henrik 2003. Landbruget, landskabet og kulturarven - hvor svært kan det være? Innlegg, workshop, Nordisk kulturlandskapskonferanse, Ulvik

Lundegren, Jan og Espersen, Søren 2003. Udvikling af samarbejdet mellem jordbruget og de ideele aktører. Notat, workshop, Nordisk kulturlandskapskonferanse, Ulvik

Elgersma og Asheim 1998. Landskapsregioner i Norge, NIJOS 2/98, Ås

Fahlbeck, Erik 2004. "Angående empiriske studier av bl a kollektiva varor och tjänster och problem kring kvantifiering, värdering och betalning för dessa". Innlegg på seminar "Jordbrukets fremtida roller", Sigtuna, Sverige. PM 4/7-03, Sveriges lantbruksuniversitet

Landbruksdepartementet 2003. For budsjetterminen 2004. St prp 1 (2003-2004). Oslo

Ljung, Magnus, 2003. Hva motiverer lantbrukare att skapa och förvalta natur- og kulturhistoriska värden i jordbrukslandskapet. Notat, workshop, nordisk konferanse, Ulvik. Institutionen för landskapsplanering, Sveriges lantbruksuniversitet, Ultuna
Miljøvernedepartementet 2003. Regjeringens miljøpolitikk og rikets miljøtilstand. St meld nr 25 (2002-2003). Oslo

Navrud, Ståle 2002. Overview of indicators on the valuation of agricultural landscapes. Proceedings from NIJOS/OECD Expert Meeting on Agricultural Landscape Indicators in Oslo, Norway. NIJOS rapport 07/2003. Ås

Navrud, Ståle 2000. Valuation techniques and benefit Transfer Methods: Strengths, weaknesses and Policy Utility. OECD, 2000 S15-38, Valuing Rural Amenities. Paris

Nesheim, Norderhaug, Ihse 2002. Beiting $i$ kulturlandskap, rapport fra nordisk seminar $i$ Natadal, Planteforsk 52/2002.

Nordisk ministerråd 2004. Jordbrukets fremtida roller, NMR 2004 (i trykk)

Nordisk ministerråd 2003. Nordens landskap, forprosjekt for oppfølging av den europeiske landskapskonvensjonen. TemaNord 2003:550. København.

Nordisk ministerråd 2000.

Jordbrukslandskapets kulturverdier-historisk udvikling, politikker og styringsmidler $i$ Norden. TemaNord 2000:520. København

Nordisk ministerråd 2000. Jordbrukslandskapets kulturverdier - utfordringer $i$ et tverrsektorelt samarbeid. Nord 2000:18 og Statens landbruksforvaltning 2001. Seminarrapport om samme tema, Hurdal, Norge 
Nordisk ministerråd miljørapport 1987. Naturog kulturlandskapet i arealplanleggingen, 1. Regioninndeling av landskap NMR Miljørapport 1987:3, Nord 1987:29. København

Nordisk ministerråd miljørapport 1987. Naturog kulturlandskapet $i$ arealplanleggingen, 2.Forvaltning av ressurser og verdier. NMR Miljørapport 1987:3, Nord 1987:29.

København

Norges offentlige utredninger 1998. Nyttekostnadsanalyser. Veiledning i bruk av lønnsomhetsvurderinger i offentlig sektor. NOU 1998:16. Oslo

Norges offentlige utredninger 1997. Nyttekostnadsanalyser. Prinsipper for lønnsomhetsvurderinger i offentlig sektor. NOU 1997:27. Oslo
Norsk institutt for jord- og skogkartlegging 2003. 3Q Tilstandsovervåking og resultatkontroll $i$ jordbrukets kulturlandskap. NIJOS rapport 11/03. Ås

Puschmann (in prep) Nasjonalt referansesystem for landskap. NIJOS, Ås

Wilhelmudvalget 2002. Landskabsvurderingen undersøgelse af internationale og danske metoder. Skov og Naturstyrelsen, Caspersen, O.H., Nellemann V., Høll, A. \& Sørensen, A. 2001.. Miljøministeriet. http://www.sns.dk/ wilhjelm/endelig/hovedrapport.htm 


\section{Vedlegg 1: Kulturlandskap i nordiske strategier og prosjekter}

Vedlegget inneholder et utvalg av mål og anbefalinger for landbrukets/jordbrukets kulturlandskap i nordiske strategier og prosjekter. Dette var en del av bakgrunnsmaterialet til den nordiske konferansen "Landskap som ressurs" i Ulvik, Norge, 2 - 4. juni 2003.

\section{TemaNord 2001:505: Bæredyktig utvikling - en ny kurs for Norden}

Et utdrag relevante mål og strategier er vist $\mathrm{i}$ rapportens kap 3.

\section{TemaNord 2001:504: Det nordiske miljøhand- lingsprogram 2001-2004 (og arbeidsprogram NFK 2001-2004)}

"Kap 4 Indsatsområder - Kap 4.1 Miljøområder - Landskab og kulturmiljø Landskabet og kulturmiljøet er under konstant forandring, men de seneste årtiers foran-dringer er sket i en fart og med konsekvenser, der ikke er set tidligere. Store dele af landskabets kvalitet og diversitet og mange kulturmiljøer er uigenkaldeligt gået tabt. Det gælder både kulturmiljøet i byerne, i det åbne land, i landbrugslandskabet og i grænsen mellem land og havet og den geologiske mangfoldighed. Det samme er tilfældet med nogle af de kulturhistoriske strukturer, enkeltmonumenter (bygninger, gravhøje mv.) og helheder (dyrkningssystemer, bebyggelsesmønstre mv.).

\section{Overordnede mål}

Sikre de nordiske landskabers diversitet og særegenhed samt rekreative anvendelse og sikre Nordens kulturmiljø i hele sin tidsmæs- sige, funktionelle og egnskarakteristiske mangfoldighed.

\section{Specifikke mål}

I det nordiske samarbejde vil man arbejde for:

- en effektiv opfølgning af den Europæiske landskabskonvention

- at styrke det nordiske kulturmiljøsamarbejde, så erfaringerne med forvaltning af kulturmiljøet udnyttes til fælles nordisk gavn, såvel nationale som internationalt.

- at styrke kulturmiljøet:

- som dimension i den integrerede miljøindsats

- som led i sektoransvaret

- for at sikre Nordens kystkultur...

\section{Aktiviteter}

- Skabe en grund for nordisk samarbejde om opfølgning af den europæiske land-skabskonvention i samarbejde med nærområderne og øvrige europæiske lande blandt andet ved at identificere de nordiske landskabers diversitet, kvalitet, problemer og muligheder.

- Videreføre og implementere den nordiske handlingsplan for kulturmiljø i landskabet(1996-2000), herunder blandt andet kompetanceudvikling, uddannelse, metodeudvikling og sektorsamarbejde såvel $i$ forhold til Norden, nærområderne og internationalt..." 
ANP 2001:711: Handlingsprogram för nordiskt jord- och skogsbrukssamarbete 2001-2004

"Kap 4 Prioriterade områden, Kap 4.3 Genetiska resurser och biologisk mångfald

Bevarandet av landskapet och dess komponenter måste alltså ske med hänsyn tagen till de kollektiva värden de bidrar med. Projekt som främjar den biologiska mångfalden $\mathrm{i}$ samklang med ett praktiskt jordbruk, skogsbruk och rennäring prioriteras. Det finns stort behov att inom Norden utbyta erfarenheter om hur man kan arbeta för att bevara ett rikt, levande och mångfaldigt kulturlandskap och hur detta kan förenas med ändringar $\mathrm{i}$ ramvillkor som följer av ändringar i internationella avtal. Under programperioden utarbetas i samarbete med miljösektorn och andra relevanta sektorer en speciell strategi för att säkra de nordiska landskapens mångfald och särprägel."

\section{ANP 2001:743: Nordisk miljøstrategi for jord- og skovbrug 2001-2004}

\section{"Kap 3 Hovedområder}

\section{ad 2) Biologisk mangfoldighed}

Ved planlægning og gennemførelse af indsatsen under miljøstrategien for jord- og skovbrug bør der gives prioritet til projekter, der fremmer den biologiske mangfoldighed i forbindelse med praktisk jordbrug, skovbrug og rendrift. Dette gælder særligt tilpasning af jord-og skovbrug der tilgodeser truede arter og biotoper med lignende forudsætninger i de nordiske lande...

Bevarelse af landskabets biologiske mangfoldighed i de nordiske lande er helt afhængig af fortsat jordbrugsdrift, og dermed i høj grad et spørgsmål om jordbrugets forudsætninger for fortsat at eksistere i tyndt befolkede områder. Den biologiske mangfoldighed omfatter såvel vilde som domesticerede arter. Mange vilde plante-og dyrearter er truede, ligesom ældre husdyrracer og kulturvækster i de nordiske lande er i tilbagegang. Denne udvikling skyldes på den ene side nedlæggelse og genvækst af dyrket land og på den anden side en mere intensiv udnyttelse af land-og skovbrugsarealer og et intensivt avlsog forædlingsarbejde, som har medført, at nye husdyrracer og plantesorter har erstattet tidligere racer og sorter, som var tilpasset lokale forhold. I forbindelse med det nordiske samarbejde behandles emnet blant andet $\mathrm{i}$ Strategi för hållbart bevarande av genetiska resurser i Norden.

\section{ad 6) Kulturmiljø og kulturlandskab} Dele af det kulturskabte landskab kan ikke opretholdes indenfor rammerne for et lønsomt jord-og skovbrug. Safremt dette landskab skal kunne bevares må det ske ud fra andre grunde end rent virksomhedsøkonomiske. Biologisk mangfoldighed, åbne landskaber og bevarelse af kulturmiljø anses af de fleste for at udgøre kollektive vardier. I de nordiske lande gives derfor forskellige former for økonomisk støtte for at bevare biologisk mangfoldighed, landskab og kulturmiljø. Ved siden af dette findes en del lovgivning for eksempel forbud mod at ødelegge fortidsminder, visse biotoper med mere. For at øge forstaelsen for bevarelse og kundskaberne om hvorledes foranstaltninger kan vedtages har nogle lande satset på informations-, uddannelses-, fortegnelses- og demonstrationsforanstaltninger. Projekter som behandler erfaringsudveksling på området bør prioriteres. Endvidere vil projekter, der belyser hvorledes bevarelse og beskyttelse kan forenes med et ikke subsidieret landbrug blive prioriteret..."

\section{Nordens landskap. Forprosjekt for oppfølging av den europeiske landskapskonvensjonen (TemaNord 2003:550)}

Det gis anbefalinger om videre oppfølging til Nordisk ministerråd, nasjonale myndigheter og forslag til videre faglig nordisk samarbeid. Prosjektet gir grunnlag for å arbeide videre med anbefalinger for hvordan landbrukssektoren kan følge opp landskapskonvensjonen. Gjennom rapporten fremmer prosjektgruppen, 
med utgangspunkt i Den europeiske landskapskonvensjonen, forslag til hvordan politikere og forvaltning, sektorer og næringsliv, organisasjoner og allmennhet og eiere og brukere kan bli mer bevisst landskapet og dets verdier. Det gis forslag til hvordan landskapet kan aktiviseres i beslutningsprosesser og bli et tydeligere element $\mathrm{i}$ arbeidet med å forvalte og utvikle verdiene $i$ våre fysiske omgivelser.

Mål, problemstillinger og utfordringer som er utgangspunkt for anbefalingene:

- behovet for å løfte fram landskapet som en tydelig og selvstendig verdi i de nordiske land i tråd med konvensjonens intensjoner.

- Fellesutfordringer for landskapsarbeidet i de nordiske landene er

- å se natur- og kulturdimensjonene i landskapet i sammenheng,

- å løfte fokus fra enkeltobjekter og småarealer til helheter og større landskap,

- å etablere landskapet som et planleggings- og politikkområde på alle nivåer og

- å øke befolkningens kunnskap, engasjement og medvirkning i landskapsarbeidet.

Prioriteringene er basert på følgende vurderinger:

- Landskapstemaet bør etableres tydelig i det nordiske samarbeidet.

- Landskapstemaet bør etableres bedre i de nordiske landene.

- Landskapsarbeidet i Norden bør styrkes faglig.

\section{Prioriterte anbefalinger}

Prosjektet gir prioriterte anbefalinger på ulike nivåer...

\section{Dagens nordiske landskap}

Det gis en kort oversikt over Nordens landskap, viktige utviklingstrekk og utfordringer. Den europeiske landskapskonvensjonen Konvensjonsteksten og forklaringene til den (explanatory report) finnes på Europarådets internettside http://www.coe.int/EuropeanLandscapeConvent ion.

Konvensjonens hovedintensjon er å fremme ivaretakelse av landskap gjennom følgende tre aktiviteter: Vern, forvaltning og planlegging. I tillegg skal den organisere samarbeid på tvers av landegrensene. Fokus settes på:

- landskap som er anerkjent som særlig verdifulle,

- landskapet som våre hverdagslige omgivelser og

- landskap som er i forfall eller er preget av negative forhold.

Et nøkkelaspekt i konvensjonen er den vekt den legger på enkeltmenneskets opplevelse og verdivurdering av landskap og på folks ønske om å medvirke aktivt til utviklingen av landskapene. De landskapene som betyr noe for oss har en verdi, og disse verdiene må ivaretas. Konvensjonen konsentrerer seg om et sett generelle og et sett særlige tiltak."

\section{Kulturmiljøet i landskabet - handlingsplan for den 3. dimension i det nordiske miljøsamar- bejde (TemaNord 1996:36)}

Under dette tema omtales to nordiske rapporter $^{20}$ :

- Historiske utvikling, politikk og styringsmidler i Norden (TemaNord 2000:520)

- Utfordringer $\mathrm{i}$ et tverrsektorielt samarbeid (Nord 2000:18) 
1. Jordbrugslandskabets kulturværdier - historisk udvikling, politikker og styringsmidler i Norden (TemaNord 2000:520)

De nordiske miljøministre har i 1996 godkendt en handlingsplan for kulturmiljøet $\mathrm{i}$ landskabet som den "3. Dimension i det nordiske miljøsamarbejde", der peger på behovet for en indsats på en række områder. Jordbrugslandskabets kulturværdier er et af de områder hvor det, som opfølgning på handlingsplanen, er prioriteret at gøre en indsats.

Jordbrugslandskabet er et produkt af årtusinders jordbrugsmæssige udnyttelse af naturgrundlaget, der fortæller om de nordiske landes jordbrugshistorie fra fortid til nutid.

Fortællinger der trues af intensivering og centralisering på den ene side og nedlæggelse af bedrifter og forfald på den anden side. Dette er en udvikling hvis konsekvenser har mange fællestræk i de nordiske lande, og hvor en fælles indsats derfor kan styrke målet om en bærekraftig jordbrugsdrift, der sikrer hensyn til jordbrugslandskabets kultur- og naturmiljøværdier.

Rapporten beskriver landevis den historiske udvikling i Norden jordbrugslandskaber, om landskabernes kulturværdier, trusler, politikker og styringsmidler i forvaltningen af jordbrugslandskabet.

\section{Jordbrukslandskapets kulturverdier - utfordringer $i$ et tverrsektorielt samarbeid (Nord 2000:18)}

Følgende tema for videre oppfølging og samarbeid er beskrevet, der det er behov for å:

- utrede nærmere jordbrukets rolle som forvalter av kulturarv og kulturmiljø

- etablere jordbruk og kulturmiljø klarere som politikkområde og integrere temaet kulturmiljø bedre i miljøpolitikken og arbeidet foren bærekraftig utvikling. Et helhetsperspektiv på miljø, der både miljø og kultur inngår i dette.
- utrede fellesnordiske perspektiver og muligheter i forhold til overordnete internasjonale prosesser. Formulere eventuelle fellesnordiske posisjoner $\mathrm{i}$ forhold til prosesser som påvirker rammevilkårene for forvaltningen av jordbrukets kulturmiljøer

- utvikle indikatorer for kulturmiljøtemaet

- utrede viktige overordnete og strukturelle utviklingstrekk i jordbruket og hva slags direkte og indirekte konsekvenser disse får for kulturmiljøet

- utfordringer knyttet til de overordnete $ø$ øonomiske rammevilkår for forvaltningen av jordbrukets kulturmiljøer.

- vurdere om det mangler virkemidler i samarbeidet om å forvalte jordbrukets kulturmiljøer.

- utrede spørsmålet om verdiskaping og næringsutvikling i tilknytning til kulturverdiene $\mathrm{i}$ jordbrukslandskapet

Seminar om jordbrukslandskapets kulturverdier, Hurdal i Norge, 2001. Gruppearbeidene pekte ut følgende tema som særlig viktige for videre nordisk samarbeid og sektorsamarbeid:

- Utvikling av arbeidet med helhetsplanlegging på det enkelte gårdsbruk - miljøplan

- Utvikle systemer og indikatorer for miljøovervåking knyttet til jordbrukets kulturmiljøverdier

- Utrede spørsmål om verdiskaping og næringsutvikling knyttet til verdiene $\mathrm{i}$ jordbrukslandskapet

- Utfordringer knyttet til forvaltning av bygninger og gårdsanlegg $\mathrm{i}$ jordbrukslandskapet

- Ønske om å utvikle gode fellesarenaer der de nordiske landene jevnlig kan møtes

\section{Kulturlandskap og jordbruk - virkemidler rettet mot kulturlandskap i Norden (NMR 1991)}

Utredningen beskriver hovedtrekk og modeller for utviklingen, drivkrefter bak endringene i landskapet, rammebetingelser for landbrukspolitikken. Prinsipper og analyser for bruk av 
virkemidler i landbrukets kulturlandskap drøftes. Noen scenarier for kulturlandskapet $\mathrm{i}$ Norden skisseres ut i fra gjeldende politiske situasjon mht EU og GATT. Det gis anbefalinger for utviklingen av virkemidler rettet mot kulturlandskap.

\section{Biotopvern i Norden (TemaNord 1989:5, 1987, 1988:108)}

Utredningen fra 1989 påpeker at mange ulike typer av slåtteenger og naturlige beitemarker er truet, og med dem en rekke plante- og dyrearter. I tillegg omtales en rekke hedearealer, lyngheier, høstingsskog (styvingstrær) og gammelt seterlandskap. Alle disse er betinget av skjøtsel blant annet ved slått, husdyrbeiting for ikke å gro igjen. Det anbefales at skjøtselen bør tilpasses områdets egenart og at skjøtsel av verdifulle arealer kan kreve høyt støttenivå

\section{Natur- og kulturlandskapet i arealplanleg- gingen (TemaNord 1987:3)}

Dette er en utredning som omfatter to rapporter: 1. Regionalinndeling av landskap og 2. Forvaltning av ressurser og verdier

\section{Del 1: Regionalinndeling av landskap}

Forutsetningene for delprosjektet om regioninndeling av landskap var

- Kunnskaper om regionale variasjoner $\mathrm{i}$ natur- og kulturlandskapet bør være et sentralt faglig underlag for å vurdere vernetiltak

- Som supplement til beskrivelse av naturgeografiske variasjoner bør kulturaspektet trekkes inn.

- Inneholde faglig underlagsmateriale for utprøving i praktiske arealplansituasjoner

Hvorfor trenger vi å klassifisere landskap?

- Referanseramme for å påvise og drøfte endringer i landskapet og vurdere konsekvenser og mulige tiltak og strategier

- Moderne vernearbeid legger vekt på representative eller typiske natur- og kulturmiljøer Rapporten gir forslag til:
1) Grunnlag for inndeling av kulturlandskap

- etter naturgrunnlag og kulturpåvirkning: Naturgrunnlag, arealbruk før og nå, kulturskapte elementer, totalinntrykket av landskapet

- kriterier for regional landskapsbeskrivelse i de nordiske land

2) Landskapsregioner og -områder på fylkesog kommunenivå for utvalgte områder

3) Landskapsregioner på nasjonalt nivå for Danmark, Finland, Sverige og Norge

\section{Del 2: Forvaltning av ressurser og verdier}

Denne delen gir en omfattende gjennomgang av kategorier for beskrivelse og vurdering av kulturlandskap:

Kategori 1 Brukerinteresser: Naturvern, kulturminnevern, landskapsbilde, friluftsliv/rekreasjon, landbruk, vannbruksinteresser, andre råvareinteresser, utbyggingsinteresser.

Kategori 2 Verneverdikriterier (utviklet fra klassiske naturvernkriterier): Representativitet, sjeldenhet, mangfold, urørthet, egenverdi, pedagogisk verdi, økologisk funksjon, symbolverdi, identitetsverdi, historisk struktur, estetiske verdier (helhet, variasjon, inntrykksstyrke)

Kategori 3 Landskapstyper: Det åpne jordbrukslandskap, det halvåpne jordbrukslandskap, den lukkede skogsbygd, det oppbrudte småskalalandskap

Kategori 4 Jordbruksarealkategori: Intensivt drevne jordbruksareal, marginalt jordbruksareal, utmark Kategori 5 Landskapsobjektklasser: Sammenhengende områder, linjedrag, enkeltobjekter

\section{I rapporten anbefales:}

1. Kommunevise landskapsanalyser etter modell av en utprøving i Rygge

2. Styrket areal og ressursforvaltning $i$ kommunene

3. Styrket kompetanse og kapasitet $\mathrm{i}$ kommunene

4. Bedre kobling mellom miljøvernhensyn og hensiktsmessige juridiske og økonomiske virkemidler. 


\section{Vedlegg 2: Et utvalg internasjonale konvensjoner, direktiver og avtaler}

- Den europeiske landskapskonvensjonen

- Convention on the conservation of European wildlife and habitats (Bern 19. September 1979)

- The European Convention for the Protection of the Architectural Heritage of Europe (Grenada, 3. October 1985)

- The European Convention on the Protection of the Archaeological Heritage, Valetta, 16. January 1992.

- Guiding principles for Sustainable Spatial development of the European Continent, Hanover 8. September 2000.

- Pan-European Biological and Landscape Diversity Strategy

- The UNESCO Convention concerning the Protection of the World Cultural and Natural Heritage (16. November 1972)

- Council of Europe's Committee of Ministers Recommendation 95(9) on the integrated conservation of cultural landscape areas as part of landscape policies

- The European Community Regulation on agricultural production methods compatible with the requirements of the protection of the environment and the maintenance of the countryside

- Convention on Biological Diversity (Rio, 5. June, 1992)

- Convention on Sustainable development

- The European Community directive on the conservation of natural habitats and of wild fauna and flora. 


\section{Vedlegg 3: Samarbeid med ideelle organisasjoner og aktører}

Felles for de typene av organisasjoner og institusjoner som er nevnt nedenfor, er at mange er representert både nasjonalt og regionalt og kanskje også lokalt og internasjonalt: Nedenfor er det gitt en oversikt over ulike typer av ideelle/frivillige organisasjoner og institusjoner der formål og virke direkte eller indirekte kan omfatte engasjement $\mathrm{i}$ jordbrukslandskapet. I tillegg kommer næringsorganisasjonene og institusjoner i landbruket.

- "Hembygdsforeninger" (Sverige og Finland) og landsbyforeninger (Danmark)

- De nordiske naturvernorganisasjoner, ornitologiske- og botaniske foreninger $\mathrm{m} \mathrm{fl}$

- Fortidsminneforeninger, historielag, $\mathrm{m} \mathrm{fl}$

- Interessegrupper for museumslandbruk og spesielle områder

- Organisasjoner innen friluftsliv, jakt og fiske

- Bransjeorganisasjoner for gårdsturisme, økologisk turisme og tematurisme

- Interesseorganisationer for utvikling, markedsføring og salg av lokalt foredlete jordbruksprodukter med regionalt særpræg.

- Firma for handel over internett som leverer direkte fra jord-til-bord

- Nordisk kulturlandskapsforbund, den eneste nordiske ideelle organisasjon for samtlige av kulturlandskapets aktører.

- Andre organisasjoner og institusjoner som er aktuelle samarbeidspartnere lokalt/regionalt: Idrettslag (stier, kart med mer), velforeninger, grunneierlag, utdanningsinstitusjoner på ulike nivåer (grunnskoler er viktigst lokalt) $\mathrm{m} \mathrm{fl}$.
Frivillige organisasjoner kan samarbeide med landbruket, landbrukets organisasjoner og lokalsamfunnene på en rekke måter for å bidra til vedlikehold og utvikling av kulturlandskapet:

- Sammen med landbruket lokalt kan de ta initiativ til utvikling av nye produkter og produksjonsmetoder, som er særlig viktig for et vel fungerende kulturlandskap

- Gjennom dannelse av forbrukernettverk kan de fremme avsetning av regionale produkter direkte fra produsent til forbruker

- De kan bidra til en langsiktig ivaretakelse av kulturlandskapet $\mathrm{i}$ areal- og samfunnsplanleggingen.

- De kan delta i konkrete oppgaver f eks: Skjøtsels- og vedlikehold, miljø- og kulturmiljøkartlegging, informasjonsarbeid og medvirke ved verdisetting og prioritering av jordbrukslandskap.

- De kan være med å sikre og utvikle regional og lokal kompetanse, som er nødvendig for å bevare autentiske metoder og jordbrukslandskap.

- De kan fremme kontakten mellom land og by gjennom utvikling av besøk, kurs, gårdsturisme, opplevelser osv.

Organisasjoner kan fungere som bindeledd mellom forskning og rådgivning, politisk nivå, forvaltning og jordbruk /befolkningen lokalt. 


\section{Nordiska ministerrådets och Nordiska rådets publikationer kan beställas hos:}

\author{
BELGIEN \& LUXEMBOURG \\ dean de Lannoy \\ Avenue du Rod, 2L/2 1190 Brusses \\ Tel -32 (0)2539516G \\ Fax +32 <0, 5330841 \\ eandelannymeuronel.be
}

\section{DANMARK}

Svensk Narsx Bogimport A/S

Esplanaden 8 B, 1263 Krabenhann K

Tel $-4533142566 \mathrm{Fax}+4533143539$

srbeibog.ck

wew:snbegck

\section{ESTLAND}

Astro Raamalud AS

Pä́nu mnt 14211317 Tallinn

$\mathrm{Tel}+372$ 64 $8485 \mathrm{Fax}+372$ a5548475

book@astro.ec

\section{FINLAND}

Ak ademiska Eckhardeln

FE 128, Centralgatan 1,

Cot01 Helsingfors

$\mathrm{Te}+350912141$

akatlasêsateminer com

uww. akalaeminen.com

\section{FRANKRIKE}

Libraine LAVOISER

14, nee de Provignt.

94236 Cactan Cadex

$\mathrm{Tel}+33(1) 47406700$

Fax $+33\langle 1\rangle 47406732$

grcup(i) ancisier.tr

waw.lawisler:t

\section{FÄRÓARNA}

H.N. Jacoosens Bckahandl

Postbeks 55, 110 Tórahavn

Tel +298 $311033 \mathrm{Fza}+295317873$

mighnj.

wwe.hni.fo

\section{HOLLAND}

De Lndeboom Interm aicnale Putlicastes

U.A, te R.s,terstraat $20 \mathrm{~A}$

ML-7482 BZ Haaksbergen

$\mathrm{Ta}+31,0,535700004$

Fax $+31<0<535729296$

booksêjeinceboom com

waw drindetcon com

\section{ISLAND}

Ma og Manning

Lavgaveg 18101 Reysjemik

Tol +354 (9j515 2500

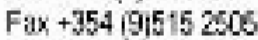

verslunerrmis

\section{KANADA}

Ranouf Publshing Company Lid

5309 Canchek Foad, Onawa,

Ontano K1.I \$.J3

$\mathrm{Tel}+1|613| 7452605$

Fax $+1(613) 7457630$

crder.degegrernoulbocks com

www.renoulbocks.com

\section{KNA}

CNPIEC

Europe Dhision 15 Gongli East Poad

P.O. Bax 88, Bejing

$\mathrm{Tel}+95105065683-\mathrm{E}$

$\mathrm{Fax}+8 \mathrm{~s} 10 \mathrm{sc} 63101$

\section{LETTLAMD}

Jana Rozes Gramatrica

Kr. Barona iela 5, 1011 Riga

Ted $+3 i 1<0<2284288$

$\mathrm{Fax}+3717370 \mathrm{D} 22$

\section{LITAUEN}

Perki Kontinentai

A. Solginseo 5, 2001 Vinius

Tel $+370(5) 2664540$

$\mathrm{Fax}+370(5) 2654565$

booksesci.t:

wWw.beoks:t

\section{NORGE}

Abajemika ASS

Postbaks 84 Bindem, 0314 Oso

Tel $+4722853030 \mathrm{Fax}+4722853080$

blakencessio in no

www.akgjemikano

\section{RUMÄNIEN}

Eurcreda s.f.I.

St Cionisie Lupu nr 65,70184 Bucurest

$\mathrm{Tel}+4015140864$

$F=x+4013129546$

\section{STOREPTTANNIEN}

The Slationery Olfice

P.O. Bcx 276, Lendon SW8 5DT

$\mathrm{Tel}+448706005522$

Fax +448706005533

customer servicespitso co uk

wWw.150.co ukibookshicp

\section{SVERIGE}

Frizes

Kundse'vice, 10647 Slockhdm

Tel $-46(0) 86009190$

Fax +46 (j) 6009191

order trizeserise

WWa.fnizes.se

\section{TYSKLAND}

UNC Verag $\mathrm{GmbH}$

Am Holgaten 10,53113 Bonn

$\mathrm{Te}+49\langle 07228949000$

$\mathrm{Fac}+\angle 9(0) 22 \mathrm{~g} 94 \$ 0222$

infoluro-varlag.de

aww.uno-veriag de

\section{UNGERN}

Euro info Service

PO Bok 1009 1245 Budapest

Tel +36 (1) 3292497

$\mathrm{Fax}+36\langle 1\rangle 3492053$

esrcinfogestoinfo.he

\section{USA}

Bernan

40ิ11-F Asserrbly Drive,

Loviam MD 20706-4391

Tel +1 (301) 4597038

$\mathrm{Fax}+1(301) 4590056$

queryebernan.com

uws.bernan com

\section{ALAND}

Lisce bok- $\alpha$ th $a$ appershanded Skapensvajenen 25, Bcx 8 , $2210 t$ Wariehamn Tel +358 [b) $1317 \quad 177$ $\mathrm{Fax}+368: 0\} 1819771$ irlopilsco.li 

